\title{
COMPORTAMENTO ESPECTRAL DE TRESS LATOSSOLOS ARGILOSOS DA REGIĀO DE LIMEIRA - ARARAS - S.P. EM RELACĀO ÀS SUAS PROPRIEDADES FÍSICAS E QUÍMICAS
}

\author{
PEDRO LUIZ DONZELI \\ Engenheiro Agrōnomo, Mestre \\ Pesquisador \\ I.A. C.
}

Orientador: Prof. Dr. GERALDO VICTORINO DE FRANCA

Tese apresentada à Escola Superior de Agricultura "Luiz de Queiroz" da Universidade de São Paulo para obtenção do título de Doutor em Agronomia. Area de Concentração: Solos e Nutrição de Plantas.

$$
\begin{gathered}
\text { PIRACICABA } \\
\text { ESTADO DE SĀO PAULO - BRASIL } \\
\text { JUNHO. } 1984
\end{gathered}
$$


$\bar{A}$

Helena, Vanessa e Camila Dedico 


\section{AGRADECIMENTOS}

A Empresa Brasileira de Pesquisa Agropecuária pela concessão de bolsa de estudos para o curso de Pós-Graduação na E.S.A. "Luiz de Queiroz".

Aos Diretores do Instituto Agronômico do Estado de São Paulo e Instituto de Pesquisas Espaciais por fornecerem as condições materiais para realização desta pesquisa.

Ao Profọ Dr. Geraldo victorino de França do Departamento de Solos da E.S.A. "Luiz de Queiroz" pela orientação e colaboração no desenvolvimento desse trabalho.

Aos Pesquisadores do INPE, Lycia Maria Moreira Nordemann, Mārio Valērio Filho e Antonio Roberto Formagio pela cooperação e valiosas sugestões.

Ao Pesquisador João Bertoldo de 01iveira da Seção de Pedologia do Instituto Agronómico do Estado de São Paulo pelas facilidades oferecidas e orientação para análises de laboratōrio.

Aos Pesquisadores Toshio Igue, Violeta Nagai e Joassy de Paula Neves Jorge da Seção de Técnica Experimental e Cálculo do Instituto Agronōmico, pela colaboração e facilidades oferecidas para anālises estatísticas.

A.o. Pesquisador Francisco de Paula Nogueira e funcionārias da Seção de Fotointerpretação. Girlene Francisco de Souza, Nicia Marcondes Zingra e Maria Lucia Pereira de Toledo pela colaboração prestada na elaboração do trabalho.

A todos que direta ou indiretamente colaboraram os sinceros agradecimentos. 
RESUMO

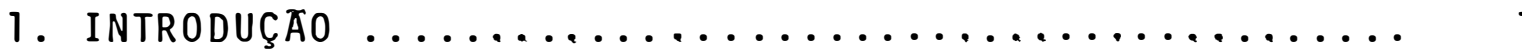

2. REVISATO DE LITERATURA $\ldots \ldots \ldots \ldots \ldots \ldots \ldots \ldots \ldots \ldots$

2.1. Sensoriamento Remoto $\ldots \ldots \ldots \ldots \ldots \ldots \ldots \ldots, 4$

2.1.1. Sensores fotogräficos-Filmes ........ 6

2.2. Medidas de cores .................... 9

2.3. Medidas de tonalidade ou cor em aerofotografias 11

2.3.1. Densidade ōtica - Transmitāncia ...... 11

2.3.2. Densitometria $\ldots \ldots \ldots \ldots \ldots \ldots \ldots \ldots$

2.4. Anālise da resposta espectral de solos em imagens aerofotogräficas ................. 14

2.4.1. Registros tonais ............... 14

2.4.2. Fotografias aēreas para mapeamento de solos com destaque para tonalidade ou cor 18

2.5. Anālise da resposta espectral de solos em labo-

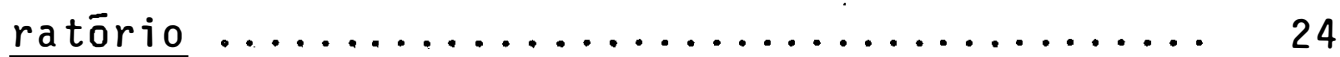

2.5.1. Propriedades espectrais de solos ...... 24

2.5.2. Espectroscopia fotoacústica ........ 31

2.6. Efeito de características do solo na reflectāncia espectral ................... 36

2.6 .1 . Cor do solo $\ldots \ldots \ldots \ldots \ldots \ldots \ldots \ldots \ldots$

2.6.2. 0 x.idos de ferro $\ldots \ldots \ldots \ldots \ldots \ldots \ldots \ldots, 38$

2.6.3. Matéria orgānica ............... 40

2.6.4. Textura e umidade ............... 42 
Pāgina

2.7. Relações entre reflectāncia espectral, registros tonais e caracterĩsticas físicas e quĩmicas dos solos ............................ 44

3. MATERIAL E METODOS $\ldots \ldots \ldots \ldots \ldots \ldots \ldots \ldots \ldots \ldots \ldots, 49$

3.1. Descrição Geral da Area Estudada .......... 49

3.1.1. Situação .................... 49

3.1.2. Geologia e Geomorfologia ........... 49

3.1 .3 . Solos ...................... 52

3.1.3.1. Unidade Barão Geraldo (LRd) .. 54

3.1.3.2. Unidade Limeira (LE.1) ..... 55

3.1.3.3. Unidade Mato Dentro (LV.5) ... 56

3.1.4. Características Analiticas das Unidades de Solo ..................... 57

3.1.5. Relações solos/geomorfologia ........ 59

3.1 .6$. clima ........................... 59

3.1.7. Vegetação natural e uso da terra ..... 64

3.2. Equipamentos ...................... 64

3.2.1. Espectrōmetro fotoacūstico ........ 64

3.2.2. Densitōmetros .............. 65

3.2.3. Estereoscópio ............... 66

3.3. Material aerofotogrāfico ............. 66

3.4. Seleção das āreas de es tudo ................ 66

3.4.1. Fatores que influenciaram a escolha da āred ........................66

3.4.2. Métodos utilizados na seleção das glebas 68' 
3.5. Anālise densitomētrica ............... 70

3.5.1. Dados de densidade ótica-Transmitāncia. ou Reflectāncia ................ 70

3.6. Anālise de espectroscopia fotoacústica ...... 71

3.6.1. Preparo das amostras ............ 71

3.6.2. Espectros de absorção ........... 71

3.6.3. obtenção de dados .............. 72

3.7. Anālise das características físticas e quỉmicas dos solos .......................... 73

3.7 .1 . Cor do solo ................. 73

3.7.2. Oxidos de ferro 1 ivres .......... 76

3.7.3. Matéria orgānica $\ldots \ldots \ldots \ldots \ldots \ldots \ldots 76$

3.7.4. Anālise granulomētrica ......... 76

3.8. Anālise estatīstica $\ldots \ldots \ldots \ldots \ldots \ldots \ldots \ldots .77$

4. RESULTADOS E DISCUSSÃo .................. 80

4.1. Comportamento espectral dos solos estudados.. 80

4.2. Relações entre cores dos solos e suas respec-

tivas imagens aerofotogräficas .......... 102

4.3. Relações entre dados de reflectāncia do espec-. tro fotoacüstico dos solos, caracteristicas físicas e quîmicas e registros de tonalidade em ae-. rofotografias.................... 105

4.4. Relações entre dados de reflectāncia densitométrica relativa dos solos, caracteristicas fïsicas e químicas e registros de tonalidade em ae-. rofotografias $\ldots \ldots \ldots \ldots \ldots \ldots \ldots \ldots \ldots \ldots \ldots$ 
Pāgina

4.5. Relações entre as características dos solos es-

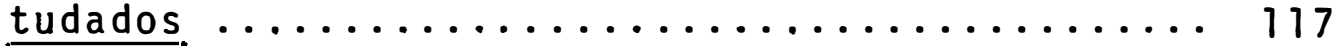

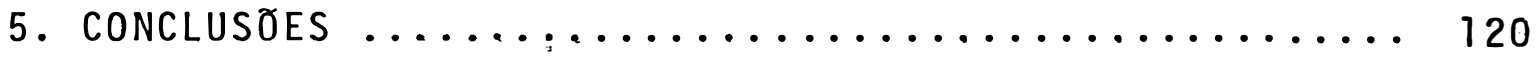

LITERATURA CITADA $\ldots \ldots \ldots \ldots \ldots \ldots \ldots \ldots \ldots \ldots \ldots \ldots \ldots \ldots$

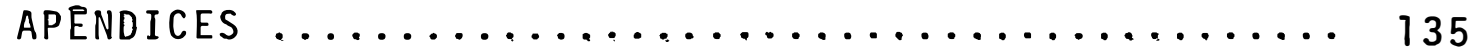


COMPORTAMENTO ESPECTRAL DE TRES LATOSSOLOS ARGILOSOS DA REGIÃO DE LIMEIRA-ARARAS - S.P., EM RELAÇÃO ÁS SUAS PROPRIEDADES FISICAS E QUIMMICAS

\author{
AUTOR: PEDRO LUIZ DONZELI \\ ORIENTADOR: PROF Q GERALDO VICTORINO DE FRANÇA
}

RESUMO

Foram realizados estudos de espectroscopia fotoacústica e densitometria de faixas espectrais em amostras de trēs latossolos argilosos, da região de LImeira-Araras, no Estado de São Paulo, Brasil.

Os espectros óticos de reflectâncià, na faixa de 450-900 $\mathrm{nm}$, foram relacionados à registros tonais em imagens aerofotográficas coloridas normais e infravermelhas e a determinadas propriedades físicas e quimicas desses solos.

A correlação entre os dados de reflectāncia do espectro fotoacústico, para determinados intervalos de comprimento de onda, com pares de variāveis selecionadas estatisticamente, atravēs dos coeficientes de correlação simples e parcial, mostrou-se significante.

Foram observados altos coeficientes de correlação simples entre paràmetros do solo, tais como, éxidos de ferro livre, matéria orgānica, cor e granulometria com a reflectancia densitomêtrica relativa em amostras de solos ou registros tonais nas imagens aerofotogräficas. 
SPECTRAL BEHAVIOUR OF THREE FINE TEXTURED LATOSOLS FROM THE LIMEIRA-ARARAS REGION, S.P., RELATED TO ITS PHYSICAL \& CHEMICAL PROPERTIES

\author{
AUTHOR: PEDRO LUIZ DONZELI \\ ADVISER: GERALDO VICTORINO DE FRANÇA
}

SUMMARY

Photoacoustic spectroscopy and spectral band densitometry studies were carried out on samples of three fine textured latosols, from Limeira-Araras region, São Paulo State, Brazil.

Optical reflectance spectra, in a wave lenght range from 450 to $900 \mathrm{~nm}$, were related to tonal densities in normal color and color infrared aerial photographic images and selected phisical and chemical properties of soils.

The relationships between reflectance photoacoustic spectra for specific wave lenght' intervals. with statistical selected pairs of variables, through parcial and simple correlation coeficientes, were significant.

It was observed high simple correlation coeficients of soil parameters, as free iron oxides, organic matter, color and granulometry with relative densitometry reflectance on the soil samples or tonal densities in aerial photographic images. 
1. INTRODUÇAOO

Nos ültimos anos, tem sido observado um grande desenvolvimento nas técnicas e métodos de medição da energia radiante absorvida, refletida ou emitida de feições terrestres. Atravēs dessas técnicas, șe utilizam diretamente os instrumentos sensores na caracterização dessas feições, ou se procura simular a geometria dos sensores, com 0 intüito de caracterizar o comportamento espectral dos alvos de interesse, relacionando-os com suas propriedades intrínsecas e dando indicação das melhores faixas do espectro para operação desses instrumentos.

Em outros casos, são utilizados métodos de laboratório, sob condições controladas, onde se tem empregado uma grande variedade de aparelhos, simulando ou não a geometria dos instrumentos sensores, com a mesma finalidade.

No caso de solos, especialmente dos solos brasileiros, tem grande interesse o conhecimento do seu comportamento espectral, principalmente quando relacionado às suas propriedades físicas e químicas, ou para conhecimento das possi- 
bilidades do emprego dos diversos produtos, resultantes do sensoriamento remoto, no levantamento ou inventārig desse recurso natural.

Os produtos de sensoriamento remoto avaliados neste trabalho foram as fotografias aéreas, das quais alguns critêrios de fotointerpretação têm sido mais estudados e pesquisados, como a drenagem superficial e aspectos do relevo, considerados os fatores mais importantes nas relações solol paisagem. A justificativa para esse fato reside na possibilidade de reprodução do modelo tridimensional do terreno, onde essas relações podem ser avaliadas, comparativamente, entre unidades fisiogrāficas diferentes.

Em nosso meio, nas ūitimas duas décadas, inūmeros pesquisadores têm estudado os critérios de fotointerpretação apticados a solos. No entantó, poucos pesquisadores têm estudado a tonalidade ou cor, como resposta espectral de solos em fotografias aēreas.

Sendo as cores em aerofotografias afetadas por uma sērie de fatores técnicos, meteorológicos è do terreno, são grandes os problemas de metodologia para aquisição de dados. O uso mais eficiente de fotos coloridas na pesquisa de solos poderā ser feito, quando baseado numa anālise detalhada da cor ou de dados de densidade ótica.

Muitas técnicas modernas de sensoriamento remoto, especialmente as imagens orbitais, de "scanner" e fotos multiespectrais, são capazes de gravar pequenas diferenças em 
reflectāncia espectral, em diversas faixas do espectro eletro-magnético, conferindo grande importāncia a esse critério. No presente trabalho, amostras de trës tipos, de latossolos argilosos foram estudadas em laboratório por espectroscopia fotoacústica, com a finalidade de se obter caracteristicas discriminativas desses solos cujos elementos de fotointerpretação convencional são muito semelhantes.

Paralelamente, os espectros óticos-acústicos

obtidos foram relacionadas com as imagens aerofotográficas desses solos, em fotografias coloridas normais e infravermelhas.

Essa resposta espectral imageada, assim como os espectros de absorção e reflectāncia, foram relacionados entre si e a determinadas características físicas e químicas desses solos, cuja semelhança dos elementos que compõem a sua paisagem, dificulta sua discriminação nos trabalhos de levantamento, conforme pesquisa realizada anteriormente por DONZELI (1979). 
2. REVISAOO DE LITERATURA

\subsection{Sensoriamento Remoto.}

A energia eletromagnética refletida ou emitida de materiais e fencomenos naturais ocorrentes na superfịcie:da terra é altamente variável em função da alteração imposta pelas condições do meio ambiente e inerente às características intrínsecas desses materiais que compõem a cena terrestre. Porēm, os fenc̄menos de absorção, reflexão é emis-' são dependem sobretudo da energia incidente, que provém do sol, como fonte natural mais importante, conforme comenta CARROLL (1973b).

0 sensoriamento remoto abrange o conjunto de têcnicas, através das quais, torna-se possível quantificar e qualificar, à distância, a energia que provém desses materiais e que constitui uma de suas características próprias, influenciada por fenomenos naturais diversos e pela sua composição fỉsica e quĩmica. 
A energia eletromagnética, quer provenha de fontes naturais ou artificiais, possui um espectro de emissão ou reflexão com características próprias das ondas eletromagnéticas, como energia, comprimento de onda e frequēncia.

0 espectro eletromagnētico é composto de di- ferentes radiações, tais como, raios cósmicos, raios-gama, raios $x$, ultravioleta, visivel, infravermelho próximo, infravermelho termal, microondas, televisão e ondas de rādio.

Conforme CARROLL (1973 b), os raios cósimicos têm o mais curto comprimento de onda e a mais alta frequência, enquanto que as ondas de rādio têm o mais longo comprimento de onda e a mais baixa frequência.

A região do visĩvel, que se estende de 380 a 780 nanōmetros, é a faixa sensoriada pelo olho humano.

A Tabela 1, adaptada de CARROLL (1973 b), ilustra a parte do espectro eletromagnético onde operam os sistemas atualmente usados em sensoriamento remoto.

\subsubsection{Sensores fotogrāficos-Filmes}

COLWELL (1966) classifica os sensores remotos em passivos e ativos. Dentre os diversos sensores atualmente em uso, as fotografias aéreas são consideradas sensores passivos, pois gravam a radiação solar que incide na terra e que é refletida para a atmosfera. Os sensores ativos, como o radar, geram a sua prōpria energia, emitindo radiação ele- 


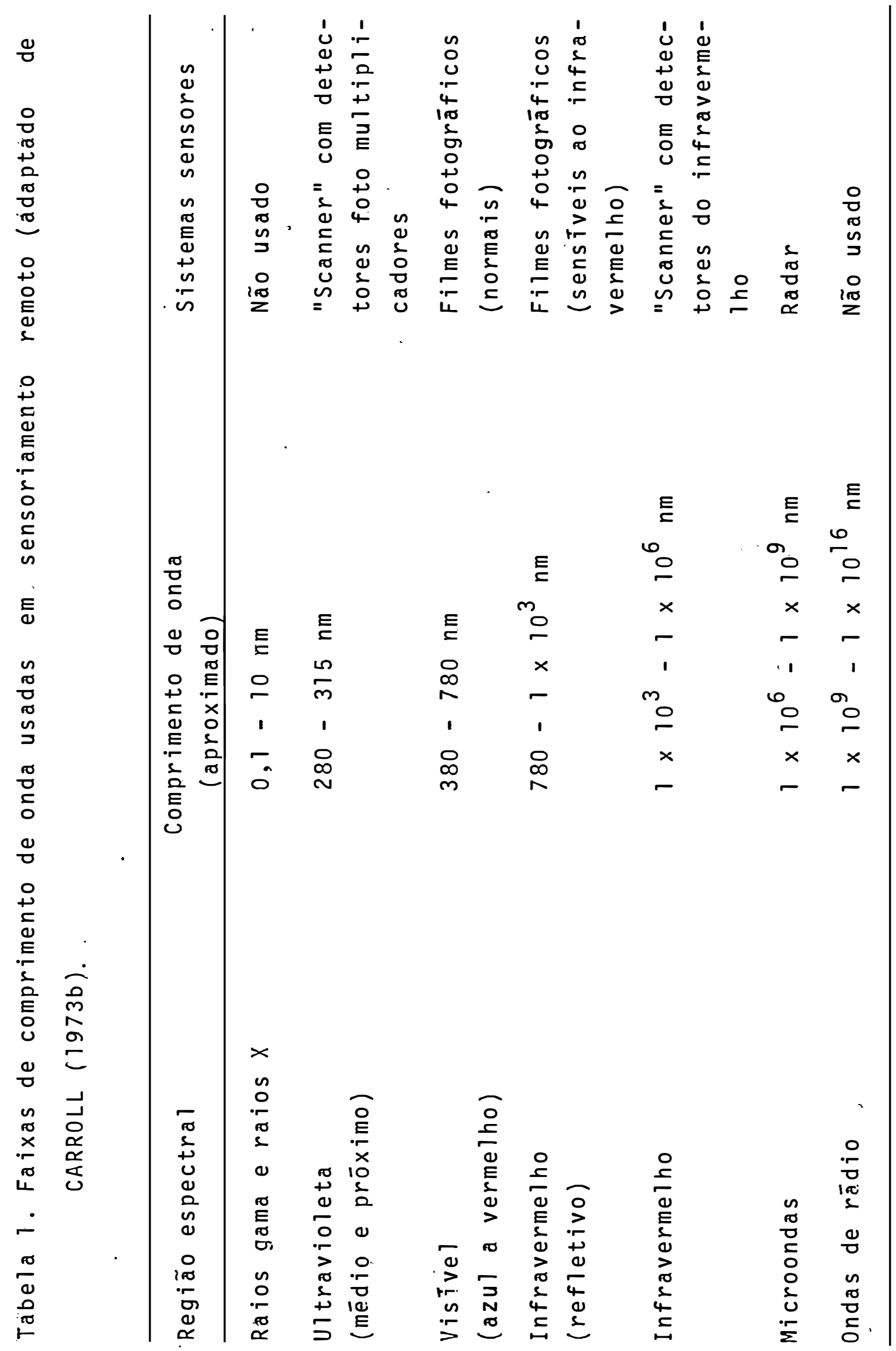


tromagnētica e gravando o sinal refletido.

Por outro lado, os sensores fotogrāficos são denominados diretos, pois gravam a energia refletida, pelos alvos diretamente em emulsões ou filmes, atravēs de lentes. Os sensores denominados indëretos são aqueles que convertem a energia detectada pelos sensores em impulsos elétricos, os quais são transformados por um tubo de raios catódicos em luz visĩvel, que pode ser gravada em papel fotogrāfico. Dessa maneira, os sensores fotogrāficos não operam em comprimentos de onda superiores a $1000 \mathrm{~nm}$.

As fotografias aéreas são ainda classificadas como sensores imageadores, pois gravam em papel fotogrāfico os níveis relativos de radiação de vārias superfịcies imageadas, na região espectral selecionada. Estes sistemas são apropriados para interpretação visual e frequentemente proporcionam boa resolução.

Os filmes são os principais elementos que detectam a energia refletida no sistema fotogrāfico.

HELLER (1971) classifica os filmes em normais e sensiveis ao infravermelho, que apresentam distintas curvas de sensibilidade espectral caracteristicas, dentro de faixas especificadas na Tabela 1 , com pequenas váriações individuais. Os dois tipos de filmes podem ser coloridos ou pretoe-branco.

Conforme explicam ESTES e SIMONETT (1975), as diferenças espectrais características de diferentes cenas da 
superfície da terra são registradas como diferenças de tonalidade pelos filmes fotogrāficos, na dependēncia da sua sensibilidade.

No caso dos filmes coloridos, estes registram as cores reais dos objetos, caso sejam coloridos normais, enquanto que nos filmes coloridos infravermelhos há uma troca das cores reais, devido às diferentes sensibilidades das camadas do filme.

FORSGARD e WHITTEMORE (1968) explanam sobre filmes coloridos usados em sensoriamento remoto. Enquanto os filmes preto-e-branco possuem apenas uma emulsão sensível à luz, sobre a base de acetato ou poliester, os filmes coloridos compõem-se de três emulsões sensĩveis às três cores aditivas primárias - azul, verde e vermelho.

TARKINGTON e SOREN (1963) explicam o processo da fotografia colorida: A cor percebida pelo olho humano pode ser produzida pela mistura das cores primārias. As emulsões do filme colorido respondem seletivamente a cada uma das cores primárias, porque através de reações químicas pode-se produzir pigmentos que irão absorver cada uma dessas trēs cores. As cores dos pigmentos correspondem às chamadas cores secundāirias, ou seja, cî̀ano que absorve o vermelho, magenta que absorve o verde e amarelo que absorve o azul.

Segundo HELLER (1971), o princĩpio de operação dos filmes colóridos é o seguinte: As três emulsões do colorido normal apresentam sensibilidade na região do azul. 
Por esse motivo, hā necessidade de utilizar-se um filtro amarelo entre a primeira camada e as seguintes, para impedir a sensibilização das outras duas camadas pela luz azul. No filme sensīvel ao infravermelho, o filtro amarelo è usado em frente à objetiva da cāmara, pois a camada de emulsão sensível ao azul é substituida por outra sensivel ao infravermelho; que por sua vez também è sensivel à luz azul. Devido à troca de cores resultantes no colorido infravermelho em rela ção às cores das regiões espectrais, esse filme è tambēm cha mado falsa-cor. A Tabela 2 ilustra tais considerações.

Conforme MARCHETTI e GARCIA (1978), pesquisas mostraram que o olho humano ē capaz de distinguir aproximadamente 2000 variações de cores em filmes coloridos, enquanto que em filmes preto-e-branco consegue-se distinguir apenas 200 tons de cinza, o que mostra a vantagem do filme colorido, pois permite a identificação de um maior nūmero de detalhes.

\subsection{Medidas de cores}

AMARAL (1975), explicando a teoria das cores, comenta: que a cor de um objeto exposto à luz solar, constitui uma de suas propriedades, podendo mudar de acordo com o tipo de luz que nele incide. Os objetos aparecem coloridos à luz branca porque refletem alguns de seus componentes espectrais, com maior intensidade que outros. 
Tabela 2. Princīpio de operação dos filmes coloridos normais e infravermelhos, segundo HELLER (1971).

\begin{tabular}{|c|c|c|c|c|}
\hline Região Espectral & Azul & Verde & Vermel ho & Infravermelho \\
\hline $\begin{array}{l}\text { Sensibilidade } \\
\text { (Pigmentos) co- } \\
\text { lorido normal }\end{array}$ & Amarelo & Magenta & Cíano & -- \\
\hline $\begin{array}{l}\text { Sensibilidade } \\
\text { (Pigmentos) } \\
\text { Infravermelho }\end{array}$ & $-\cdot$ & Amarelo & Magenta & Cíano \\
\hline $\begin{array}{l}\text { Cor no Colorido } \\
\text { Normal }\end{array}$ & $A \geq 41$ & Verde & Vermelho & -- \\
\hline $\begin{array}{l}\text { Cor no Infraver- } \\
\text { melho }\end{array}$ & -- & $A \geq u 1$ & Verde & Vermelho \\
\hline
\end{tabular}


A cor é uma das propriedades de mais difícil conceituação qualitativa, desde que depende de fatores psicológicos, alēm de fatores físicos:

Mētodos para representação grāfica das cores foram desenvolvidos por Munsell, ISCC-NBS. (Inter-Society Color Council - National Bureau of Standards) e CIE (Comission Internationale de L'Eclairage), citados por RIB (19.68).

A teoria das cores, exposta por STRANDBERG (1968), mostra que todas as cores podem ser obtidas pela combinação de apenas três cores primárias denominadas aditivas: vermelho, verde e azul.

As trēs cores aditivas primárias somadas duas a duas formam as cores subtrativas secundārias cíano, magenta e amarelo; quando somadas as trēs, reproduzem a luz branca. Partindo das cores secundárias pode-se também reproduzir as cores primárias, como no processo da fotografia colorida.

A cor de um objeto pode ser determinada quantitativamente por meio de espectrometria ou por densitometria, conforme exposto por RIB (1968).

DONZELI (1979) efetuou medidas de cores em amostras de solos por densitometria, utilizando densitōmetros de reflexão difusa.

2.3. Medidas de tonalidade ou cor em aerofotografias

2.3.1. Densidade ótica-Transmitāncia

Conforme EASTMAN KODAK (1972), a densidade é 
um termo convencional que expressa o quanto o filme ou imagem fotogräfica absorve de um feixe de luz incidente.

A densidade ótica è uma função logarítmica, podendo ser definida como o logaritmo da razão entre a luz incidente e a luz transmitida. Assim, tem-se:

$$
D=\log \frac{P_{0}}{P}=\log \frac{1}{T}
$$

sendo (Po), fiuxo de luz incidente; (P), fluxo de luz transmitida; ( $T$ ), transmitāncia.

SCARPACE e FRIEDERICHS (1978) explicam o conceito de densidade em imagens coloridas, que é possível ao fotointērprete determinar. Quando a densidade é avaliada atravēs de filtros, representando uma faixa espectral que pode ser larga ou estreita, em função da transmitância espectral do filtro, ela é denominada densidade integral espectral. Assim, tẹm-se :

$$
D\left(\lambda_{a}\right)=\log \frac{P_{0}(\lambda a)}{P(\lambda a)}=\log \frac{1}{T(\lambda a)}
$$

sendo que $\lambda$ a representa um comprimento de onda determinado ou uma faixa de comprimento de onda determinado. A transmitância, no caso, é relativa aos fluxos de luz incidente e transmitido, à função de transmitância do filtro e à sensibilidade relativa do densitómetro ao fluxo de luz. 


\subsubsection{Densitometria}

As medidas de densidade ōtica são ūteis para caracterização quantitativa da tonalidade ou cor em aerofotografias coloridas, sendo determinadas atravēs' de densitômetros.

Os densitōmetros são instrumentos que procedem à comparação, por meio de uma fotocēlula, entre - uma amostra e um padrão de densidade conhecida.

os densitómetros podem medir a densidade especular ou difusa.

Segundo SCARPACE (1978), a densidade especular é medida quando o fluxo de luz incidente é colimado e o fluxo transmitido è medido atravēs de pequena abertura. Em medidas de densidade difusa, a luz incidente pode ser difusa ou colimada, porém o fluxo transmitido ē medido com uma tolerāncia angular. Os densitcometros podem também ser de trans missão ou de reflexão, conforme sejam utilizados para medidas em transparéncias ou cōpias em papel, respectivamente. Se a luz incidente for selecionada por filtros, pode-se medir a densidade de faixas espectrais, ou densidade espectral integral em fotografias coloridas.

RIB (1968) descreve uma técnica, utilizada tambēm por DONZELI (1979) seguindo a mesma metodologia, que permite a caracterização da cor em imagens aerofotogrāficas atravēs de medidas densitomētricas. 
GARCIA e MARCHETTI (1977) comentam sobre a necessidade de se quantificar o critério da tonalidade ou cor em aerofotografias coloridas, atravēs de leituras densitométricas, que independem de critérios pessoais. Esses autores argumentam que, em sua pesquisa, tanto as notações de Munsell como a caracterização da cor, não são tão esclarecedoras como os valores de densidade ótica.

LUEDER (1959) ressaltia que, para a avaliação das diferenças de tonalidade em fotografias aéreas, os densitōmetros são muito superiores ao ôlho humano, que :é incapaz de discernir todas as variações de densidade registradas nas fotos.

2.4. Anālise da resposta espectral de solos em imagens ae-. rofotogrāficas

2.4 .1 Registros tonais

A alteração espectral da radiação que incide nos diversos alvos à superfície da terra, refletindo com intensidades diferenciadas, irá caracterizar cada material pesquisado pelo sensoriamento remoto, conferindo-lhe uma identidade espectral única.

ESTES e SIMONETT (1975) comentam que as variações tonais de cores ou de densidades, constituem os registros de diferenças espectrais decorrentes da reflexão da energia incidente em diferentes objetos fotografados à superfĩcie da Terra. 
Para MONTGOMERY et alii (1976), com base na literatura, em fotografias aéreas deve ser usado o termo tonalidade para o brilho relativo das imagens, enquanto que, no imageamento multi-espectral deve-se usar o termo resposta espectral. A justificativa, neste caso, é que o brilho relativo na imagem pode ser decorrente de energia refletida ou . emitida pelo alvo devido às suas propriedades termais, enquanto que as fotos aēreas registram apenas a energia refletida:

Para HOFFER et alii (1972), a tonalidade foi considerada como critērio de extrema importāncia na interpretação de imagens de satēlite e mesmo para fotos aéreas de pequena escala. A medida que são usadas escalas maiores, esse critério decresce em importāncia, devido aos muitos fatores que nela influem.

KOFFLER (1982) lembra que, em imagens Landsat, a tonalidade ganha ainda mais importạncia por refletir o comportamento espectral dos objetos em diferentes faixas do espectro eletromagnético. No imageamento multiespectral, mesmo em grandes escalas, deve-se ressaltar a importāncia da tonalidade quando é decorrente da emissividade dos alvos, devida às suas propriedades termais.

RICCI e PETRI (1965) analisam os fatores que podem influir na tonalidade fotogrāfica em um único vōo, para tomada de fotografias de grande escala. os aspectos relaciona dos aos materiais èàs têcnicas de processamento fótogräfi- 
co sendo constantes e estando em condições ideais, enumeram os seguintes fatores como importantes na variação da tonalidade: ângulo de incidencia do sol, topografia do terreno, posição relativa da câmara fotográfica, características e condições do solo e da vegetação.

STEINER e HAEFNER (1965) ponderam que, para obter maior eficiência na quantificação da tonalidade ou cor em imagens aerofotogräficas, a influência de fontes de variação deve ser minimizada, e para isso é indispensavel uma padronização no processamento fotográfico. Ressaltam que um fator importante que influi na tonalidade é a iluminação heterogènea no plano focal da camāra fotográfica, causada pela variação do àngulo de reflexão solar, sendo este um fator externo de diff̣cil controle. Recomendam a escolha de um horārio de elevada altitude solar para tomada das aerofotos, evitar lentes supergrande;angulares, e restringir as medidas às partes centrais das fotos.

ESTES e SIMONETT (1975) enumeram outros fatores que influem nos valores de densidade ou tonalidade fotográfica, tais como: características da cena, tipos de filmes, filtros, efeitos sazonais e escala das imagens.

RAY (1963) ressalta que a medida da densidade ótica da imagem por meio de densitômetros, que quantifica o critério da tonalidade, é ūtil para comparações entre características do terreno, quando se consideram os fatores que interferem na medida, tais como: variação. do àngulo de inci- 
dência do sol, topografia, posição relativa da câmara fotogrāfica e características dos solos e da vegetação.

LUEDER (1959) separa esses fatores em trēs categorias:

a) Fatores do terreno: topografia, solo (umidade e matēria orgānica), rocha, vegetação;

b) Fatores técnicos: características dos-materiais e equipamentos, técnicas de exposição, técnicas de processamento;

c) Fatores meteorolōgicos e climatolōgicos: neblina, nuvens, àngulo de incidência da luz solar, estação do ano.

KOFFLER (1982), trabalhando com fotografias coloridas infravermelhas e imagens Landsat para mapeamento da cobertura vegetal de uso do solo, encontrou altas correlações entre dados anālogos de razões espectrais entre canais e dados densitométricos em filtros, (canal 5/canal 7); do LANDSAT (verde/vermelho), em fotos infravermelhas coloridas.

PIECH e WALKER (1974), ao descreverem um processo de calibração necessāria para a transformação de dados de densidade em dados de reflectância real de objetos fotografados, justificam que as densidades óticas avaliadas por densitômetros são variaveis, tanto em função do processamento fotogrāfico, como do tempo de exposição da cena fotografáa à luz do sol. Este, pör sua vez, depende das condições meteorológicas, altura de vôo e condições de iluminação do alvo, co- 
mo por exemplo, a porção da luz do sol irradiada para a atmosfera ou transmitida até o alvo.

2.4.2. Fotografias aēreas para mapeamento de solos com destaque para tonalidade ou cor

Segundo WEISMILLER e KAMINSK (1978), a intensificação da pesquisa sobre o uso de fotografias coloridas e falsa-cor para mapeamento de solos, em vāriás partes do mundo, se deu na década de 1960. Os resultados começaram a evidenciar que os limites entre unidades de solo poderiam ser melhor discriminados com o uso de aerofotos coloridas do que pancromáticas. No entanto, devido ao alto custo das fotografias em cores e infravermelhas coloridas, as fotografias aéreas preto-e-branco ainda são as mais üteis nos levantamentos de solos.

Para quantificação dos parāmetros tonalidade e/ou caracteristicas da cor em fotografias coloridas e infravermelhas, tendo em vista mostrar as diferenças espectrais das imagens analisadas, mais especificamente diferenças entre solos, vārios autores têm desenvolvido as mais diversas técnicas.

COSTA (1979), em sua revisão de literatura, coloca as fotografias aéreas como o tipo mais comum e útil dos sensores remotos, sendo que, comparada a outros sensores, tem como importantes atributos a seu favor a resolução espectral e a fácil identificação de aspectos da paisagem: 
AMARAL e AUDI (1972) colocam a tonalidade fotogrāfica diferencial como importante critērio a ser usado na fotopedologia, aliada a outros critérios de fotointerpretação, para a discriminação de unidades de mapeamento de so10s.

Para CARROLL (1973a), a cor ou tonalidade como critêrio para interpretação de solos torna-se evidente quando são consideradas as características do solo a ela associadas.

EVANS (1979), analisando imagens : fotogrāficas de solos expostos, destacam a importanncia da cor como padrão de fotointerpretação, sendo que os padrões de cor são menos visiveis quando os solos se apresentam com altos teores de umidade.

Vários autores têm encontrado altas correlações entre tonalidade em aerofotos com tipos de solos diferentes e suas propriedades.

KRISTOF (1971) classificou seis diferentes assinaturas espectrais, podendo separar e delinear unidades de solo a partir de fotografias aéreas.

PIECH e WALKER (1974) argumentam que a informação fotomētrica contida na cor da imagem fotogrāfica é uma têcnica promissora para complementar a anālise fisiogrāfica. Mudanças na densidade da imagem podem ser relacionadas à reflectāncia do soló e, consequentemente, às suas propriedades fisicas. 
MATHEUS et alii (1973), analisando imagens multiespectrais obtidas por aeronave, conseguiram bons resultados na preparação de mapas de levantamento de solos. As propriedades de reflectāncia da superfície de quatro glebas de solos nus foram classificadas por comparação com padrões de reconhecimento. Os mapas de distribuição espacial das classes espectrais de solos, impressos por computador, foram comparados às condiçc̃es de campo.

CARNEIRO e AZOLIM (1976), analisando comparativamente imagens orbitais e fotos aéreas, concluiram que a composição colorida "falsa-cor" foi a imagem mais informativa para a finalidade em questão, pela anālise da tonalidade ou cor.

MYERS (1979) destaca as vantagens das fotografias coloridas para mapeamento de solos, sendo que essas vantagens tornam-se evidentes quando são consideradas as caracterīsticas do solo associadas a sua cor, ou quando são usados métodos dedutivos de associação da resposta espectral de culturas associadas a solos.

CIHLAR e PROTZ (1972) relatam que os filmes coloridos gravam muitas informações específicas com respeito às unidades de mapeamento de solos e recomendam que, para a obtenção de medidas densitométricas aplicadas a solos, estas devam ser obtidas em āreas e não em secções transversais.

WESTIN e FRAZEE (1976) descrevem as carácterīsticas da tonalidade e cor, além de outros padrões aplica- 
dos em seu programa de levantamento de solos, que lhes possibilitaram separar unidades fisiográficas que necessitaram apenas pequeno refinamento na "checagem" de campo.

EVANS (1979) salienta em sua pesquisa, que os contrastes entre solos são melhor evidenciados em aerofotografias multiespectrais nas faixas do vermelho e infravermeTho prōximo; e que os padrões tonais diferenciais são -melhor caracterizados em aerofotografias do que em fotos terrestres, porque a luz se difunde melhor na direção vertical do que na horizontal.

DOMINGUES (1960), analisando comparativamente fotos coloridas e pancromáticas para levantamento de solos concluiu que as imagens coloridas permitiram maior precisão no delineamento de unidades de solo e ganho de tempo nesse trabalho, exigindo dos fotointérpretes apenas uma alta acuidade visual para cores. Usando as notações de Munsel, y. encontrou alta correlação entre cores dos solos amostrados e cor registrada nas aerofotos coloridas.

EVANS et alii (1976), pesquisando o uso de aerofotografias para separação e identificação de solos em Fenland, Inglaterra, concluiu que os valores de densidade de imagem são insuficientemente precisos para a determinaçao de propriedades específicas de solos; e que:as correlações entre valores de dencidade tonal e propriedades dos : solos são maiores quando grándes áreas sao avaliadas. Concluiu também, que a densidade tonal foi um critério muito eficiente quando 
usado em conjunção com outros critērios de fotointerpretação. CIHLAR e PROTZ (1972), trabalhando com medidas de densidades óticas sobre filmes coloridos, com a finalidade de discriminar diferentes unidades de solo, demonstraram uma sensivel diferença entre negativos coloridos e um negativo preto-e-branco hipotético. Com a finalidade de avaliar a aplicabilidade de filmes coloridos e pancromäticos no mapeamento de solos, em condições similàres, esses autores consideram a soma das densidades obtidas nos filtros vermelho, verde e azul como medidas equivalentes às obtidas em negativos preto-e-branco.

PIECH e WALKER (1974) argumentam que o levantamento de solos por fotointerpretação tem sido baseado na anālise fisiogrāfica e avaliação visual das propriedades tonais; e que, embora essas tēcnicas tenham sido vantajosas, atravēs de quantificação desses parāmetros o intérprete pọderia avaliar melhor as propriedades dos solos com respeito ao acerto ou extensão desejada.

VALENTINE et alii(1971) concluiram que as fotografias pancromáticas se equivalem às coloridas e infravermelhas para mapeamento de solos de terrenos montanhosos, enquanto que a precisão aumenta significativamente de $72 \%$ para $84 \%$ a favor das fotografias coloridas normais e infravermelhas para mapeamento de solos em planịcies contendo depósitos aluviais, marinhos ou deltaicos.

KUHL (1970) relata que, através dé métodos quantitativos, foi possível medir a precisão na interpretação 
de características do solo em fotos pacromäticas, coloridas e infravermelhas coloridas, sendo que as duas ültimas mostraram-se superiores às pancromāticas. GARCIA (1975) e ANSON (1968), desenvolveram pesquisas semelhantes, confirmando esses resultados.

PARRY et alii(1969), usando fotografias coloridas em uma pesquisa para levantamento de solos, que apresentavam diferentes classes texturais, demonstraram a superioridade das fotografias coloridas sobre as pancromäticas na diferenciação entre sēries de solo e na distinção entre variaçôes no teor de umidade e matēria orgānica. Quanto às cores, nem sempre obtiveram a exata correspondencia entre as cores dos solos no campo e as cores examinadas em cōpias em papel dos negativos originais.

ANSON (1970), apös testes comparativos entre fotografias pancromäticas e coloridas, adverte sobre a maior complexidade dos problemas relacionados com os métodos a serem usados na obtenção dos dados, quando se utilizam fotografias coloridas.

EVANS (1979) comenta que as relações entre tonalidade fotogräfica e propriedades fịsicas dos solos são Unicas para cada localidade, devido ao grande nümero de fatores variảveis dos solos responsāveis por suas respostas espectrais.

PIECH e WALKER (1974) explicam como informações detalhadas de umidade e textura do solo podem ser obti- 
das de imagens fotogrāficas atravēs da anālise da informação fotomētrica da imagem. Esses autores obtiveram medidas de densidades ótica e as transformaram em valores de reflectāncia real registrada nas imagens fotogrāficas através de uma calibração das medidas. Recomendam que a interpretação fotomētrica deve ser feita através de razões espectrais entre reflec- . tância do vermelho e azul.

CIHLAR e PROTZ (1972) realizaram pesquisa, com. o propōsito de determinar se os filmes coloridos contêm a informaçäo de resposta espectral possível de ser usada na separação de unidades de solo. Efetuaram medidas densitométricas ao longo de secções transversais sobre negativos coloridos. Esses dados foram submetidos a uma anālise discriminatória. Os resultados demonstraram que os negativos coloridos são capazes de gravar informações, as quais poderão ser usadas na separação de unidades de solos.

MACE (1980) conseguiu mapear, com grande precisão, solos em nível de séries por anālise digital microdensitométrica, em solos preparados para plantio, em Wisconsin (USA).

2.5. Anālise da resposta espectral de solos em laboratório. 2.5.1. Propriedades espectrais de solos

A resposta em reflectāncia espectral de solos, assim como de plantas, "deve conter informações concentradas 
em uma faixa espectral relativamente estreita, definida pelas propriedades de absorção da luz pelos seus constituintes, $\bar{a}-$ tomos e moléculas.

Essa informação torna-se de grande valor no sensoriamento remoto, na discriminação das melhores bandas espectrais para a finalidade em questão.

CROWN e PAWLUK (1974) sustentam. a afirmativa de que o solo, tanto em condições naturais como em amostras no laboratório, tem uma resposta espectral caracteristica e bem definida, estando estreitamente correlacionada às suas propriedades físico-químicas, como foi comprovado por inúmeros pesquisadores.

Obukhov, citado por MONTGOMERY et alii (1976), trabalhando em laboratōrio, determinou coeficientes de reflexão relativa na parte visível do espectro $(0,4$ a $0,75 \mu \mathrm{m})$, expressando a razão entre a reflexão do objeto estudado e a reflexão de uma superfície absolutamente branca (padrão). 0 estudo foi conduzido com um espectrômetro de laboratório e com uma série de filtros de banda larga. Concluiu, que nessas condições, para se obter bons resultados em laboratório, o solo amostrado deve ser seco ao ar e passado em peneira de malha de $1 \mathrm{~mm}$ de diāmetro. Além dessa técnica foi usada ùma esfera integradora para medir a reflectância sob diversos " àngulos, simulando os registros em condições naturais. A região do vermelho foi a que se mostrou mais eficiente na caracterização dos sollos. 
MAY e PETERSEN (1975) relatam que mapas gerados por computadores, usando as. assinaturas espectrais obtidas em laboratörio e atravēs de dados de "scanner", montado em aeronave, foram similares a mapas de lavantamento de campo por processos tradicionais. Aproximadamente $90 \%$ de acerto foi obtido entre mapas produzidos por assinaturas espectrais de solos sensoriados pelo "scanner" em comparação com suas reflectāncias. espectrais obtidas em laboratório.

MONTGOMERY et alii (1976) discutem a influēncia do tamanho das partículas do solo na reflexão da luz em condições de laboratōrio. A reflexão difusa da superfície dos agregados esféricos, sendo ideal em relação a agregados de tamanho irregular, que refletem menos luz, que se extingue entre eles. 0 diāmetro dos ägregados parêce naño ter influência na reflectāncia total, porém esse autor recomenda que se padronize a amostra em peneira de malha de lmm de diāmetro.

MONTGOMERY et alii (1976) não recomendam o uso de vidro sobre as amostras, principalmente para determinação de cor do solo, uma vez que pode alterar os valores em relação aos valores Munsell, guardando com eles uma relação constante.

WEISMILLER e KAMINSK (1978) afirmam que, em geral, os solos são caracterizados por uma alta resposta espectral no infravermelho termal, uma relativamente menor resposta no infravermelho reflectivo e uma variada resposta nas 
porções visiveis do espectro.

KRISTOF e ZACHARY (1971) obtiveram resultados promissores no reconhecimento de padrões de solos da região de Indiana, USA, pela anälise de dados espectrais mediante o uso de computador. Usaram doze faixas de comprimento de onda do espectro eletromagnëtico, desde 400 a $2600 \mathrm{~nm}$, obtendo assinaturas espectrais de amostras de sēries de solo jā conhecidas. As sêries de solo puderam ser facilmente identificadas e discriminadas, quando a variação entre elas foi maior que dentro da prōpria sërie.

CIPRA et alii (1980) efetuaram medidas de proprịedades espectrais de solos com espectrorradiômetro. Simultaneamente, medịam a radiāncia em imagens do satēlite Landsat dos solos desprovidos de vegetação. A radiāncia nas imagens Landsat e os valores de reflectāncia estavam altamente correlacionados em todas as bandas do Landsat.

A anālise de variância mostrou que dezesseis unidades de mapeamento, consistindo de onze séries de solo, puderam ser separados em cinco grupos de reflectāncia espectral distintos, com base na cor superficial desses solos e em quatro grupos com base em outras características diferenciadoras das sëries.

Segundo FORMAGGIO (1983), o primeiro pesquisador a caracterizar curvas de reflectância espectral de solos, organizando-as segundo as suas formas, foi CONDIT (1970), que as enquadrou em trēs tipos gerais no intervalo de 0,32 a 1,0 micrômetro. 
STONER e BAUMGARDNER (1981), .. analisando 485 amostras individuais da camada superficial de solos de vārias partes do mundo, : selecionaram cinco diferentes curvas de reflectāncia espectral de solos minerais, com base no teor de matēria orgānica e ōxidos de ferro, como características diferenciais. Sugerem assim, mais dois tipos de curvas de reflectáncia em adição ãs descritas por CONDIT (1970). Uma das modificações sugeridas é a que caracteriza as curvas de reflectância de solos amostrados em Londrina, Paraná, Brasils em solos "Typic Haplorthox", apresentando altos teores de ferro, baixos teores de matéria orgânica e textura fina. Essa curva de reflectância ē a única que apresenta como característica uma inflexão de declividade, passando a decrescer por volta dos 750 nanómetros. Este tipo de curva não mostrou as bandas de forte absorção da água por volta dos 1450 nanōmetros e 1950 nanômetros que outros tipos apresentaram, Fig. 1 (e). Porêm, apresentam a faixa característica de absorção de ferro férrico entre 800-900 nm, descrita por STONER et alii (1980). Na Fig. 2 è apresentada a curva de reflectāncia de STONER e BAUMGARDNER (1981), relativa ao trecho compreendido entre 400 e 1000 nanōmetros, onde se pode observar a tendência decrescente após 700 nanōmetros e a faixa de absorção de ferro prōximo a 900 nanōmetros. 


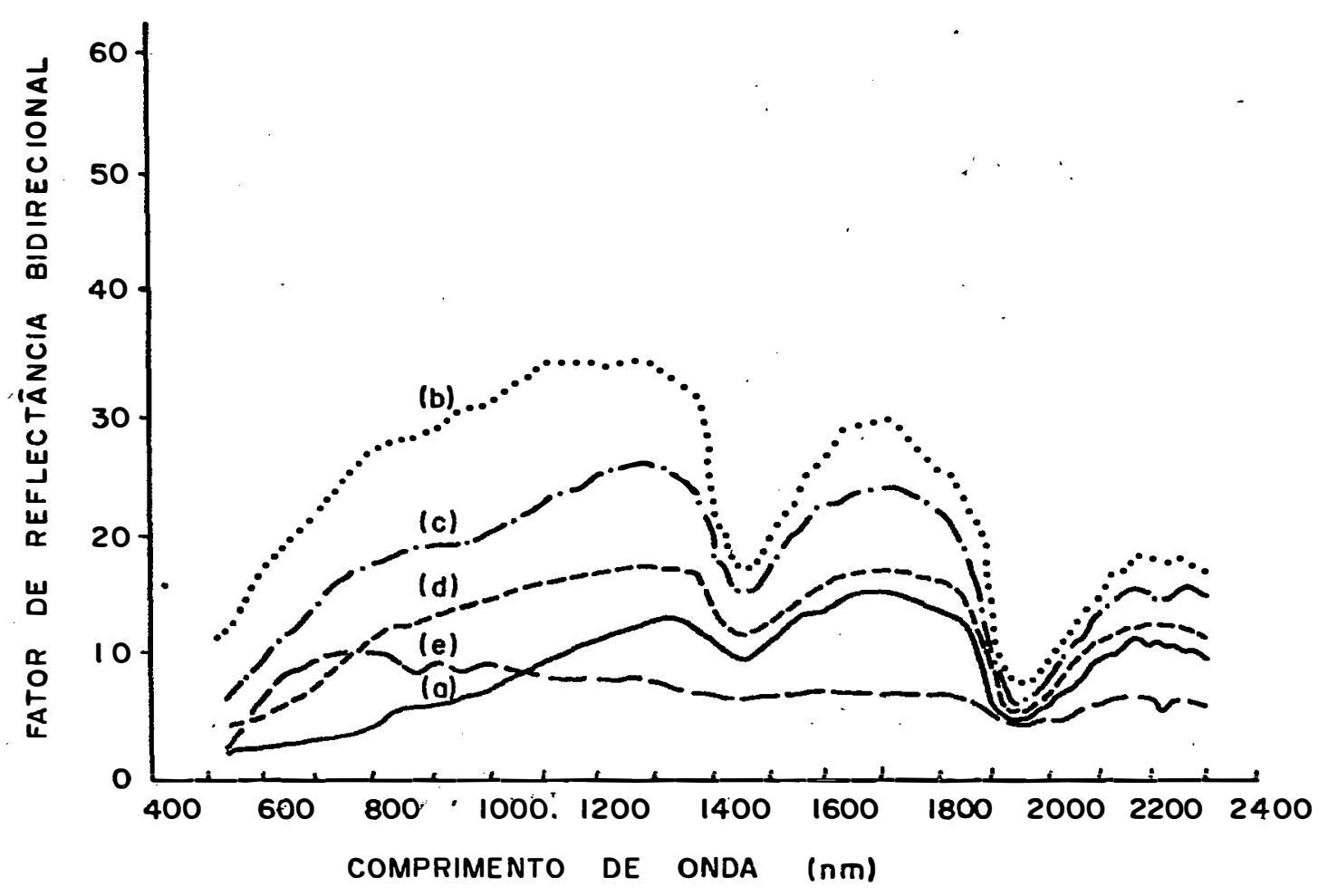

Fig. 1 - Espectro de reflectância de amostras de horizonte superficial de 5 solos minerais (a) alto teor de m.0. $>2 \%$, textura moderadamente fina (b) baixo teor de m.o. e médio teor de ferro $\mathrm{Fe}_{2} \mathrm{O}_{3}(1-4 \%)$ (c) baixo teor de m.o.. mēdio teor de ferro (d) alto teor de m.o., textura moderadamente grosseira (e) alto teor de ferro, textura fina. Extraído de STONER e BAUMGARDNER (1981). 


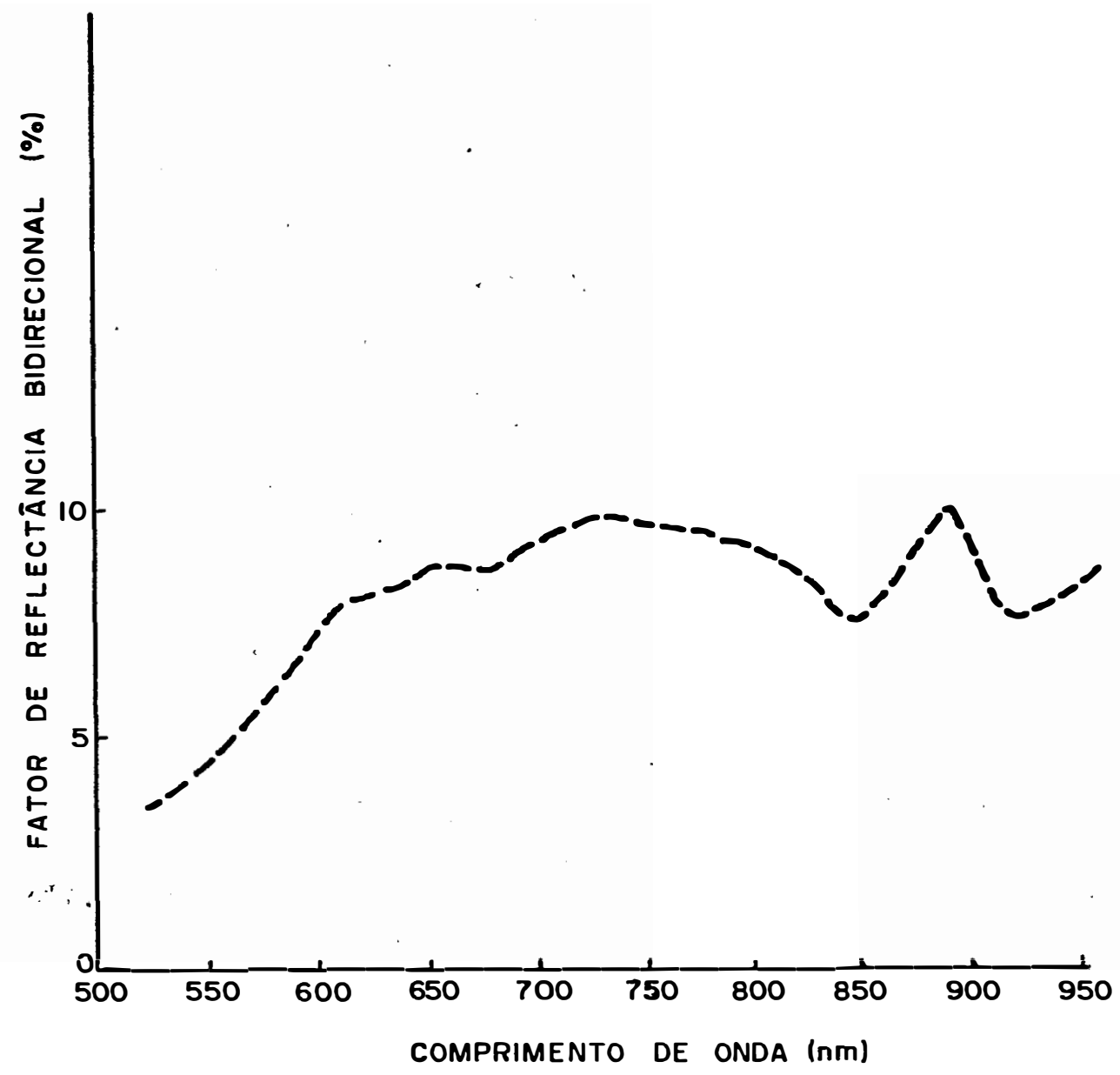

Fig. 2 - Espectro de reflectāncia de amostras de horizontes superficiais de solos com altos teores de ferro, baixos teores de matéria orgānica e textura fina, entre 550-950 nm. (Typic Haplortox). Adaptado de STONER E BAUMGARDNER (1981). 


\subsubsection{Espectroscopia Fotoacūstica}

De uma maneira simplificada, o processo de funcionamento do espectrōmetro ótico-acūstico ē descrito por ROSENCWAIG (1977). Fig. 3.

$\mathrm{Na}$ espectroscopia fotoacūstica de sōlidos as amostras a serem estudadas são colocadas dentro de uma célula fechada contendo um. gás, no caso ar, e um microfone ultrassensịvel. A amostra ē então iluminada com uma luz monocromática oscilante. A energia absorvida pela amostra é transformada em energia de vibração, a qual é transferida às moléculas do ar que entram em movimento produzindo som. 0 sinal recebido pelo microfone, resultante do som produzido pela vibração do ar, é processado por um amplificador. A potência desenvolvida ē gravada como uma função do comprimento de onda da luz incidente. Dessa maneira, o espectro ótico-acústicio obtido corresponde: ao verdadeiro espectro ótico de absorção das amostras.

ROSENCWAIG (1977) argumenta que uma das princìpais vantagens da espectroscopia fotoacústica (E.F.) è que ela permite obter um espectro similar ao espectro ótico de absorção, de qualquer tipo de material sōlido ou semi-sōlido, podendo ser cristalino, em forma de pó ou amorfo. Esta capacidade è baseada no fato de que apenas a luz absorvida é convertida em som. 0 espalhamento de luz, que representa um obstāculo nas técnicas convencionais de espectroscopia de vārios 


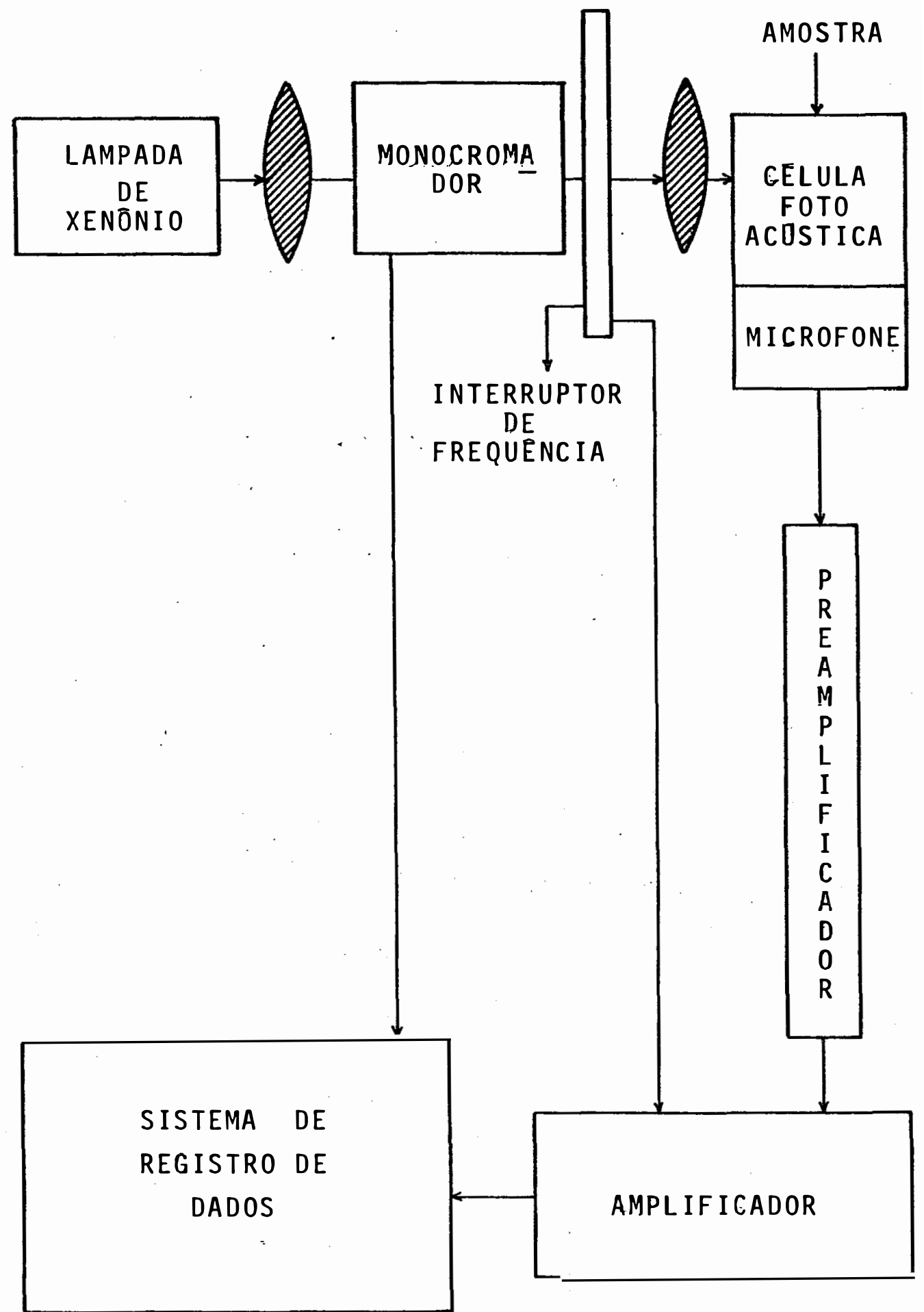

Fig. 3 - Representação esquemática do espetrômetro fotoacūstico. Rosencwaig (1977). 
tipos de materiais sôlidos, no caso da. E.F: não constitui problema. Alem disso, provou-se experimentalmente que bons dados da absorção ótica podem ser obtidos com a técnica da E.F. de materiais completamente opacos à luz transmitida.

Aplicações importantes em pesquisa e anālise de sôlidos e semi-sâlidos, orgānicos, inorgânịcos e biológicos, como no caso dos solos, são descritos por ROSENCWAIG (1977).

MOREIRA-NORDEMANN et alii (1983) obtiveram, em laboratōrio, espectros fotoacūsticos ou espectros óticos de absorção na faixa de 200 a 2000 nanômetros, de vārios tipos de solos, a fim de ser estudado o comportamento termal dessas amostras em função da radiação incidente. A correlação entre o espectro fotoacústico e a absorção de energia solar pela superfície do terreno foi estabelecida para intervalos de comprimento de onda correspondentes. Os resultados obtidos nesse trabalho sugerem a possibilidade de se usar a espectroscopia fotoacüstica como um novo mētodo, de anālise espectral, aplicada a solos, auxiliando na seleção das faixas espectrais para definição de canais nos instrumentos sensores. Nesse trabalho foi provada a importancia do teor de matéria orgânica no comportamento termal do solo. Solos ricos em matēria orgānica (carbono total), tendem a exibir altas temperaturas em função da energia incidente. Em todas as amostras examinadas, a absorção de energia foi relativamente grande na faixa espectral de 260 a $400 \mathrm{~nm}$ e maior que nos comprimentos 
de onda do visivel e infravermelho prōximo.

Tambēm BOWERS e HANKS (1965) fazem consideraçôes sobre as elevadas temperaturas de solos escuros. Esse fato ē atribuĩdo ã grande absorção de energia solar radiante que esses solos apresentam.

MOREIRA-NORDEMANN et alii (1983) apresentam em seu trabalho dois tipos principais de espectros fotoacústicos. As amostras ricas em matēria orgānica, que apresentam um pico de absorção em torno de $300 \mathrm{~nm}$, Fig. 3 (a), e as ricas em fer ro, onde se pode observar um patamar entre 260 e $540 \mathrm{~nm}$, Fig. 3 (b), e faixa de absorção na região espectral do laranja e verme iho.

Esses autores observaram tambēm uma correspondência entre a cor dos solos, teor de matēria orgânica e $\mathrm{Fe}_{2} \mathrm{O}_{3}$, com a intensidade do sinal fotoacústico. 0 solo de coloração mais escura, que tambēm é o mais rico em ferro e. matêria orgânica, foi o que apresentou o mais forte sinà fotoacistico e exibiu a mais alta temperatura.

outra observação interessante $\bar{e}$ que, ao comparar os dados de intensidade do sinal fotoacístico com os teores de $\mathrm{Fe}_{2} \mathrm{O}_{3}$ e matēria orgānica, a autora e colaboradores notaram que as amostras ricas em matéria orgānica dão um sinal fotoacüstico mais intenso do que aquelas onde hả um teor comparāvel de $\mathrm{Fe}_{2} \mathrm{O}_{3}$, porque a matēria orgānica absorve maior quantidade de eneirgia. 


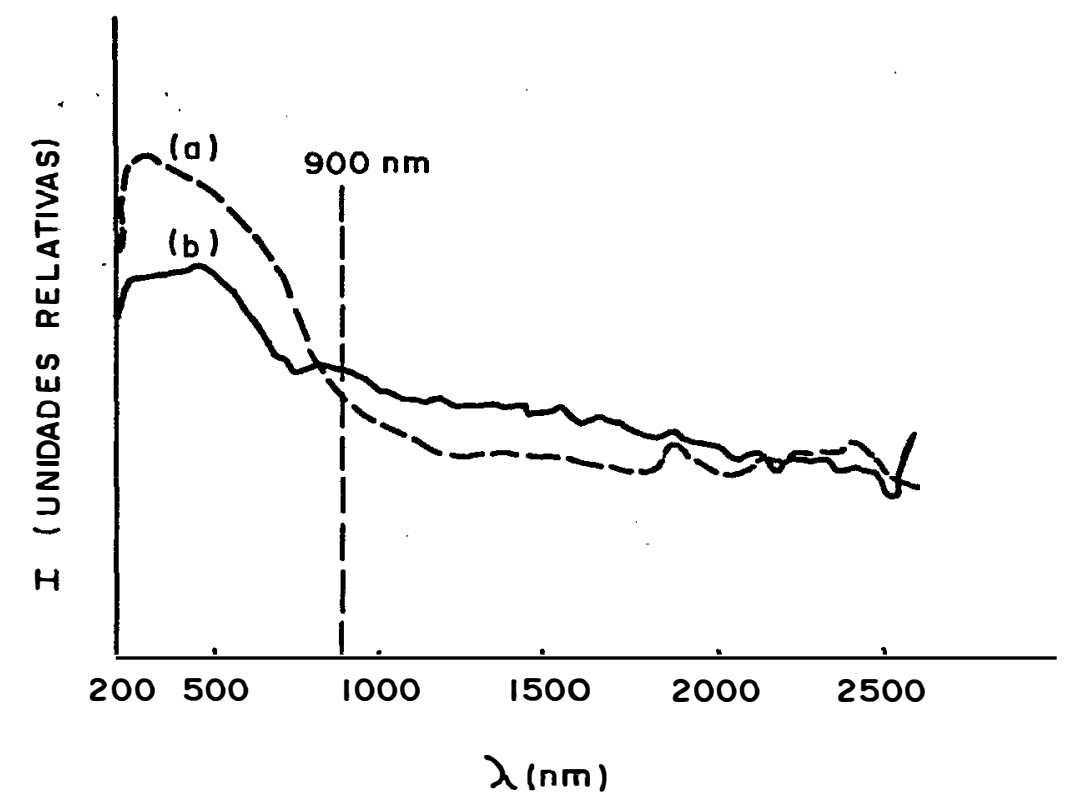

Fig. 4 - Espectros fotoacústicos de amostras de horizontes superficiais de solos ricos em matēria orgānica. (a) e ricos em $\mathrm{Fe}_{2} \mathrm{O}_{3}$ (b). Extraído de MOREIRANORDEMANN et alii (1983). 
2.6. Efeito de características do solo na reflectância. espectral

2.6.1. Cor do solo

STONER et alii (1980) advertem que, ao se comparar as cores correlacionadas às tabelas com a reflectáncia espectral dos solos, deve-se levar em consideração que a faixa de comprimento de onda da percepção humana da reflectāncia visivel extende-se de 380 a 780 nanōmetros, enquanto que as medidas espectrais podem se estender por uma faixa variável, bem maior. No entanto, a cor pode ser resultante de intensas absorções fora da região do visivel, estendendo-se essa influência para essa região. Daí a importância de se examinar uma faixa mais larga do espectro eletromagnético para perfeita caracterização das propriedades espectrais do solo correlacionadas à sua cor.

KRISTOF et alii (1980) reafirmam essas observações, recomendando porēm a faixa 580 a 610 nanōmetros da região do visĩvel como extremamente útil em sua pesquisa para caracterização quantitativa da cor do solo.

STONER e BAUMGARDNER (1.981) ponderam que a classificação americana moderna ou "Soil Taxonomy" (Soil Survey Staff, 1975), utiliza a reflectāncia na faixa do visível ou cor do solo, como uma característica diferenciadora para muitas classes, senḑo uma parte essencial. na definição de certos horizontes diagnósticos. 
COSTA (1979) adverte que a cor do solo, conforme é avaliada pelos pedâlogos, não ē precisa e sua utilidade poderia ser muito aumentada, para correlações com outras propriedades do solo, quando determinada atravēs de espectrometria.

COSTTA (1979) relaciona os fatores que podem influenciar as leituras visuais de cor, como hora do dia, ângulo do sol, nebulosidade e defeitos da visão. As leituras de laboratōrio tambēm estão sujeitas a erros, porēm sendo padronizados os procedimentos, esses erros tendem a ser menores.

Obukhov e orlov, citados por MONTGOMERY et alii (1976), MYERS e ALLEN (1968), VALERIO FJLhO et alii (1976) demonstraram em seus estudos que os solos possuem reflectividade espectral característica, altamente correlacionada à sua cor e concluiram que a região do vermelho e infravermelho do espectro são as mais favoraveis para essa caracterização.

COSTA (1979) estabeleceu equações de regressão baseadas nos componentes da cor dos solos para estimar outras propriedades dos solos. As propriedades do solo mais significantes, relacionadas à sua cor, são a matéria orgānica, teor de argila e óxidos de ferro.

CIPRA et alii (1980) relatam em sua pesquisa que as cores dos horizontes superficiais do solo influenciaram as caracterịsticas espectrais medidas. Os resultados dessa pesquisa sugerem que, em situações onde a cor da superfície dos solos estā altamente correlacionada com outras carac- 
terīsticas, hā possibilidade de se detectar diferenças entre solos atravēs de suas caracterīsticas espectrais.

MCKEAGUE et alii (1971), trabalhando com solos do Canada, encontraram alta correlação entre o "valor" da cor e os teores de matêria orgānica. Esses autores relatam que essa característica pode ser estimada por anāilise de regressão a partir do parāmetro "valor", que tem um componente reflectivo facilmente mensurāvel por espectrometria.

Tambēm MONTGOMERY et alii (1976) apresentam uma correlaçâo significante ao nīvel de 1\% entre "matiz" e a porcentagem de $\mathrm{Fe}_{2} \mathrm{O}_{3}$ e entre "valor" e porcentagem de argila ou teor de matēria orgânica. Estes autores não observaram relação significativa entre "croma" e as caracterîsticas estudadas.

CARROLL (1973) afirma que a cor, na interpretaçẫo de solos em imagens aerofotográficas, pode-ser muito importante quando são usados mētodos dedutivos de associação de condições das culturas com as caracterīsticas dos solos.

Tambēm CROWN e PAWLUK (1974) fazem essa afirmativa. concluindo que existe a possibilidade de se usar o vigor das plantas cultivadas, como indicador de características de sub-superficie, principalmente se os dados forem obtidos quando as piantas atingirem seu vigor máximo.

2.6.2. бxidos de ferro

Segundo STONER et alii (1980), faixas de..ab- 
sorção de $\mathrm{Fe}_{2} \mathrm{O}_{3}$ podem ser vistas em certas curvas de reflectāncia por volta dos 700 e $900 \mathrm{~nm}$. Largas faixas nesses comprimentos de onda frequentemente ocorrem em solos com altos teores de ferro, enquanto em solos relativamente pobres em ferro pode ser observada uma faixa mais estreita de absorção aos 900 nanômetros.

Karmanov, citado por COSTA (1979), concluiu que o grau de hidratação dos hidróxidos do solo está relacionado ã reflexão da luz na porção visível do espectro, sendo a reflectância diretamente proporcional à hidratação.

De acordo com STONER et alii (1980), diferentes formas de óxidos de ferro estão associadas às cores vermelhas e amarelas dos solos. Os dados espectrais, em seu trabalho, indicam que a absortāncia no infravermelho próximo estã associada à cor dos solos com altos teores de ferro. COSTA (1979) cita os oxissóis de regiōes tropicais que tendem a tornar-se mais vermelhos $\bar{a}$ medida que aumentam os teores de öxidos de ferro.

Segundo ADRIEN et alii (1982), tanto os óxidos de ferro como a mineralogia da fração argila constituem parâmetros adicionais que afetam a reflectância espectral dos solos. Argilas dos tipos montmorilonita e caulinita exibem diferentes propriedades espectrais. Nos solos onde predominam altos teores de ferro parece haver um decréscimo geral na reflectāncia espectral a partir dos $750 \mathrm{~nm}$, mas que não pode ser atribuido a um único fator, uma vez que essa: característica 
ocorre em associação com outras características desses solos. MONTGOMERY et alii (1976) tambēm afirmam que a significância dos $\bar{x}$ idos de ferro na reflectāncia aumènta com o aumento do comprimento de onda no espectro, particularmente nas regiões do visível e infravermelho prōximo.

MATHEWS et alii (1973) relatam que altos teores de ōxidos de ferro reduzem a intensidade de reflectāncia especialmente na faixa 500 - 1200 nanometros.

Obukhov e Orlov, citados por MONTGOMERY et alii (1976), encontraram coeficientes de reflexão de solos na região 500 - $640 \mathrm{~nm}$ inversamente proporcionais aos teores de óxidos de ferro, sendo este um dos principais fatores correlacionados à reflexão espectral da superfície dos solos.

\subsubsection{Matēria Orgānica}

A influēncia' da'màtéria orgānica nas propriedades dos solos ê bem conhecida e estudada. Alēm de influenciar as cores dos solos, a matéria orgānica está diretamente relacionada à capacidade de troca catiōnica, retenção de umidade, estrutura, erodibilidade e tambēm à reflectāncia espectral dos mesmos. Como demonstrado por diversos autores, entre os quais BOWERS e HANKS (1965), PAGE:(1974), STONER e BAUMGARDNER (1981.), AL-ABBAS et alii (1972), o teor de maté- . ria orgānica estā inversamente correlacionado à reflectāncia espectral. 
BAUMGARDNER et alii (1970), atravēs da anālise digital de dados multiespectrais do "scanner", delinearam mapas de classes de solos com diferentes teores de matéria orgânica. Uma anālise de regressão linear entre teores, de matéria orgânica e resposta espectral de 200 amostras superfíciais dos solos estudados mostrou um coeficiente de correla. çao significativo, $r=(-0,72)$.

ADRIEN et alii(1982) citam um trabalho de Stoner e Baumgardner de 1979, onde estes autores indicam que a regiâo do verde no espectro eletromagnético, compreendida entre os comprimentos de onda 0,52 - 0,62 micrōmetros, mostra altas correlações com o teor de matéria orgânica de 481 amostras de solos, pertencentes a diferentes classes taxonōmicas .

Conforme BAUMGARDNER et alii (1970), o teor de matéria orgânica influencia acentuadamente a reflectância espectral dos solos. Em solos com altas porcentagens de matéria orgānica (maiores que $2 \%$ ), hā um mascaramento do efeito de outras propriedades na reflectāncia espectral.

STONER e BAUMGARDNER (1981) complementam essa afirmação, ressaltando que, em solos minerais, apenas solos com altos teores de $\mathrm{Fe}_{2} \mathrm{O}_{3}$ (maiores que 4\%), poderā haver mascaramento dos efeitos de altos teores de matéria orgânica. MOREIRA-NORDEMANN et alii (1983) caracterizaram espectros fotoacusticos de amostras de solos ricos em matéria orgânica, que apresentaram um pico de absorção, bastan- 
te proeminente em torno dos $300 \mathrm{~nm}$.

Segundo ADRIEN et alii (1982), apesar dos vārios trabalhos jā conduzidos, mostrando a influéncia da matêria orgânica nas propriedades espectrais dos solos, ainda existem dīividas, e diferentes opiniōes permanecem com respeito à região do espectro eletromagnético mais adequada para medir as propriedades espectrais de solos com diferentes teores de matēria orgānica.

\subsubsection{Textura e umidade}

Tem sido observado que a diminuição no diāmetro das partículas do solo causa um correspondente aumento na sua reflectância, principalmente em solos arenosos.

Segundo STONER et alii (1980), esse fato é explịcado, possivelmente, pela formação de uma superfície lisa, com poucos vazios, a qual poderia vedar a entrada de luz. 0 inverso acontece com solos argilosos e de textura média ó que pode ser explicado talvez pela capacidade desses solos reterem maiores teores de umidade e também estarem associados com matēria orgânica, especificamente no caso dos solos argilosos.

KRISTOF et alii (1980) relatam que a textura do solo pode ser melhor diferenciada nas faixas 0,73-0,76 mi-. crōmetros e 0,88-0,90 micrómetros; sendo que as faixas de 2,07-2,09 e 2,16-2,19 micrômetros mostram-se eficientes na quantificação do teor de argila dos solos, quando estes pos- 
suem menos de $20 \%$ de argila e menos de $2 \%$. de matēria orgānica.

Parece haver uma concordância geral entre os autores, como BOWERS e HANKS (1965), MYERS e : ALLEN (1968), HOFFER e JOHANNSEN (1969), PARKS e BODENHEIMER (1973), que para um aumento no teor de umidade, mantendo-se os demais fatores constantes, hā um correspondente decréscimo na reflectância espectral dos solos, em todos os comprimentos de onda.

Quanto ã influência do teor de umidade na refléctāncia, vārios autores como BOWERS e HANKS (1965), MONTGOMERY (1974), tēm afirmado que este não influencia a forma das curvas espectrais, e sim a variação de amplitude da reflectāncia.

COSTA (1979) cita uma pesquisa realizada em 1970 no LARS (Laboratory for Applications of Remote Sensing da Universidade de Purdue), em que a reflectância espectral de solos arenosos e argilosos foi medida em laboratōrio para mostrar os efeitos do teor de umidade na reflectância espectral. Em ambas as categorias de solos observa-se que a reflectância diminui com o aumento da umidade no solo. Notou-se também que as curvas de solos argilosos mantēm a mesma configuração com a mudança no teor de umidade, o que não acontece com solos arenosos.

MATHEWS et alii (1973) relatam que o tipo de argila influencia $\dot{a}$ forma e a intensidade da curva de reflectāncia em toda a faixa estudada 500 - 2600 nanōmetros. 
Segundo diversos autores, como STONER et alii (1980), VANDERBILT et alii (1980), KRISTOF et alii:(1980), ADRIEN et alie (1982):, CIPRA et alii (1971), as curvas espectrais da maioria dos solos apresentam faixas de forte absorção de āgua em 1,45 e 1,95 micrōmetros, o que sugere uma específica locação dasimoléculas de āgua em sîtios determinados.

ADRIEN et alii (1982) citam o trabaltho de Stoner. e Baumgardner de 1980 , orde estes concluiram que a região do espectro eletromagnético que apresenta maiores correlaçōes com a umidade do solo corresponde à faixa de. 2,08 a 2,32 micrômetros.

PETERSON et alii (1979) mostram tambēm a possibilidade de determinação do teor de umidade de solos a partir da sua resposta espectral, atravēs de anāilise de regressao.

2.7. Relações entre reflectāncia espectral, registros tonais e caracteristicas físicas e químicas dos solos.

Muitas propriedades fîsico-quỉmicas dos solos estão intimamente correlacionadas, o que muitas vezes permite, atravēs da medida de um ou mais parāmetros, estimar-se a quan tidade ou caracterīsticas de outros.

Conforme comentam MONTGOMERY et alii equações de regressao tēm sido estabelecidas para a determinação da CTC de certos solos em função dos teores de argila e 
matéria orgānica. A cor está intimamente celacionada ao conteūdo de ferro total. e. tem sido expressa como uma função do conteūdo de ferro, matēria orgānica, pH e tipo de argila, tornando-se cada vez mais, com os avanços da tecnologia de sensoriamento remoto, um critērio muito significativo na discriminação de solos.

Numerosos estudos têm descrito a contribuição relativa de parāmetros do solo tais como matéria orgānica, umidade, composição granulométrica, estrutura do solo, ōxidos de ferro, mineralogia, cor e CTC, no comportamento espectral dos solos. Dentre outros, citam-se os trabalhos de BOWERS e HANKS (1965), COSTA (1979), HOFFER e JOHANNSEN(1969), MYERS (1979), MATHEWS et alii (1973), MONTGOMERY et alii (1976), MYERS e ALLEN (1968), PETERSON et alii (1979), PLANET (1970), STONER E BAUMGARDNER (1981)..

$\mathrm{Na}$ ültima dēcada, muitos estudos tēm sido conduzidos para reconhecimento de padrões de resposta espectral característica de solos, com medidas em laboratōrio, no campo e em imagens aerofotogrāficas e de satēites. Os resultados têm sido bastante promissores e as unidades de solo foram discriminadas sempre que as variações entre elas são maiores do que dentro das prōprias unidades.

Os trabalhos de diversos autores como PAGE (1974), MONTGOMERY et alid (1976), STONER e HORVATH (1978); CIPRA ret alii (1971), evidenciam que algumas caracteristicas como o teor de matēria orgānica, $\mathrm{Fe}_{2} \mathrm{O}_{3}$ e granulometria constituem-se em pa- 
rāmetros altamente correlacionados à reflectāncia espectral e aos registros tonais nas imagens.

CIHLAR e PROTZ (1973), estudando as relações entre as caracterĩsticas físicas e quĩmicas dos, solos e sua resposta espectral, concluem que distintos grupos de unidades de mapeamento de solos foram definidos com base no "valor" de Munsell, matêria orgânica e granulometria, mas nem todas as unidades de solo puderam ser discriminadas. Seus resultados demonstraram que os solos não podem ser mapeados com precisão com base apenas na sua resposta espectral, mas que estas devem constituir uma informação adicional, juntamente com outros critêrios.

EVANS et alii (1976), trabalhando com solos desprovidos de vegetação, encontraram altas correlações com o teor de umidade dos solos e foto-tonalidade. A cor e o teor de umidade foram relacionados ao teor de matéria orgānica no so10. 0 aumento do teor de matéria orgânica estava associado ao aumento na retenção de umidade e cores mais escuras. Nesse caso, o teor de umidade foi consequência do maior teor de matéria orgānica. .

VALERIO FILHO et alii (1976), quantificando as respostas espectrais de diversos solos atravēs de medidas de densidade, conseguiram resultados que permitiram a caracterização de três grupos de solos: a) Latossolo Roxo; b) Latosso10 Vermelho Escuro fase arenosa e c) Areias Quartzosas. Concluiram que a textura mostrou-se mais importante que a estru- 
tura do solo, em termos de reflectividade espectral na região do infravermelho.

FORMAGGIO (1983), estudando o comportamento espectral de quatro solos do Estado de São Paulo, concluiu que os Latossolos Roxos e Vermelhos Escuros šão espectralmente separäveis do Latossolo Vermelho-Amarelo e Podzólico Vermelho Amarelo, porēm não puderam ser separados entre si. Entre os parâmetros que influenciaram a reflectáncia dos solos destacam-se a cor e os conteüdos de ferro e matēria orgānica.

umidade foi importante nas condições de campo. Houve uma correlação relativamente alta entre os trēs níveis utilizados na coleta dos dados espectrais de solos no laboratório, campo e satêlite.

DONZEL I (1979), atravēs de medidas de densidade ótica em aerofotografias coloridas normais e infravermelhas e em amostras da camada superficial de três latossolos, estabeleceu correlações entre as cores dos solos e as cores das suas respectivas imagens fotogräficas. Encontrou altos coeficientes de correlação entre as cores das imagens e as cores dos solos determinadas por densitometria. Concluiu que foi posivel observar diferenças entre solos, principalmente quando a cor foi importante nessa diferenciação. 0 Latossolo Vermelho-Amarelo, comparado aos Latossolos Roxo e Vermelho Escuro, apresentou diferenças altamente significativas nas cores das imagens aerofotogräficas. Porẻm, entre os Latossolos Roxo e Vermelho Escuro as diferenças foram minimas. Observou- 
se apenas uma diferença significativa ao nivel de $10 \%$ de probabilidade, entre esses dois solos, em transparēncias infravermelhas coloridas, utilizando-se de estatística não-paramētrica. 
3. MATERIAL E METODOS

3.1. Descrição geral da ārea estudada.

3.1.1. Situação

A ārea estudada situa-se na região centro-sudeste do Estado de São Paulo, acompanhando o eixo entre as cidades de Limeira e Araras, dentro da região fisiogrāfica denominada "Depressão Periférica", tendo como coordenadas $22^{\circ} 27$.'S e $47^{\circ} 25^{\prime} \mathrm{W}$ Gr., que localizam o centro da ärea.

Essa ārea dispõe de uma faixa de cobertura multi-sensorial por aeronave, executada pela NASA em 1969, segundo INPE (1975), cujo material aerofotográfico foi parcialmente utilizado nesta pesquisa. A Fig. 4 mostra a localização da ārea estudada.

3.1.2. Geologia e Geomorfologia

A província geomorfológica da "Depressão Periférica" compreende uma região fisiogrāfica de feição caracteristica, assim denominada por Morais Rego, citado por 


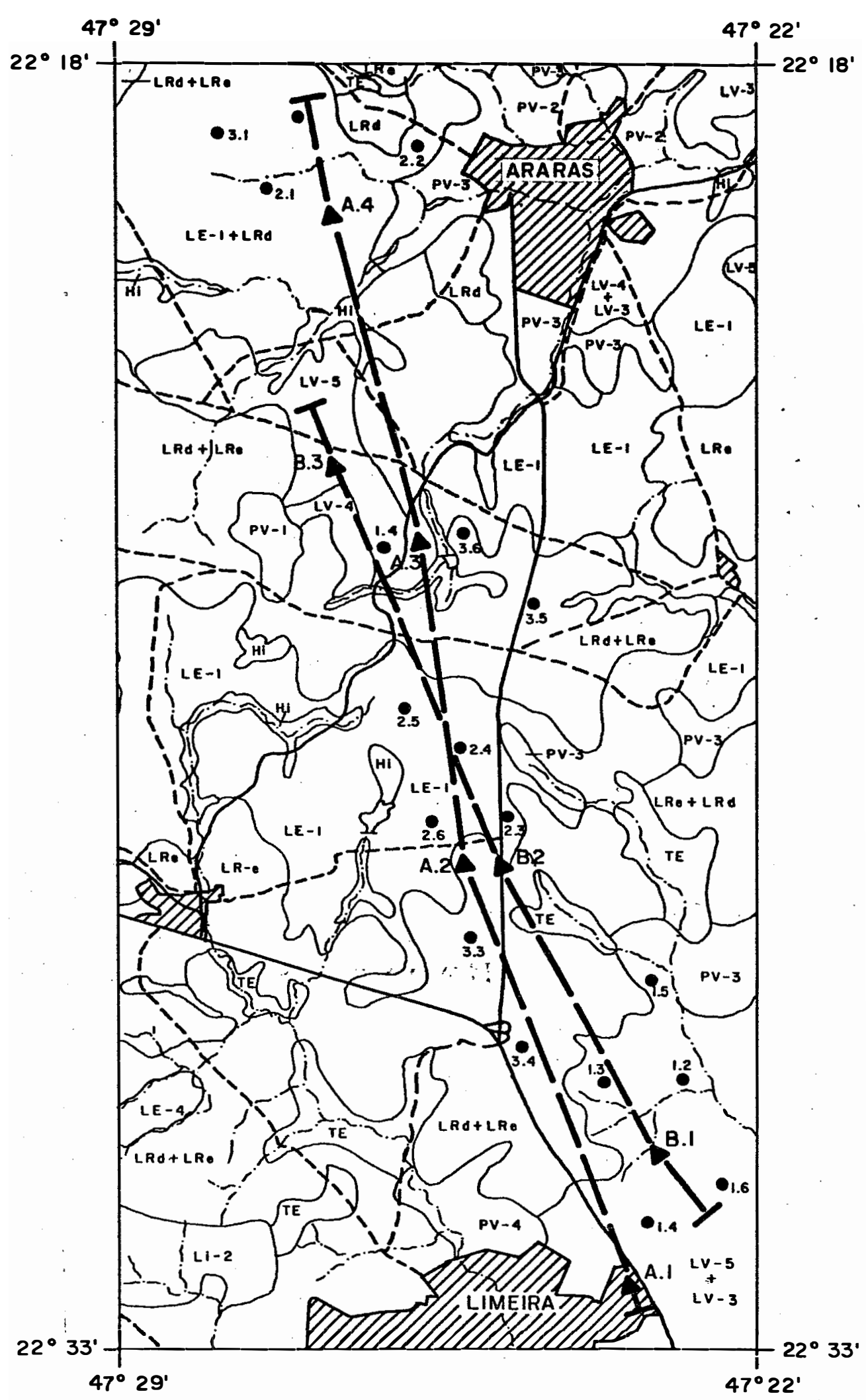

Fig. 5 - Localização da área estudada, unidades pedológicas (LR), pontos amostrados (1.2): e faixa de cobertura multisensorial (1inhas A e B). Escala 1:120.000. INPE (1975), OLIVEIRA et ali $i$ (1982). 
ALMEIDA (1964). Esse autor a descreve como uma ārea rebaixada pela erosão geológica, situada entre duas outras regiões fisiogrāficas: "Planalto Atlāntico" a Sudeste e "Cuestas Basālticas" a Noroeste do Estado.

Numa subdivisão trîplice dessa região fisiogrāfica, ocupa em sua quase totalidade a zona denominada por ALMEIDA (1964) de Médio Tietē, e em pequena porção, a zona compreendida pelo divisor de águas da bacia hidrográfica do rio Moji-Guaçu.

o relevo è suave ondulado, constituido por baixas colinas de formas suavizadas e topos aplainados, cuja declividade não ultrapassa os $5 \%$, com vertentes longas de perfil convexo.

A quase totalidade da ārea é representada por espesso capeamento de material argiloso, bastante intemperizado e proveniente de remanejamento, ocupando as cotas mais altas, conforme OLIVEIRA E ROTTA (1973).

A esses depósitos argilosos correspondem solos muito profundos, porosos e de baixa fertilidade, descritos por OLIVEIRA et alii (1982).

Esses sedimentos argilosos capeiam rochas sedimentares relacionadas ao grupo Tubarão (arenitos, siltitos, diamictitos), grupo Passa-Dois, com as formações Irati (dolomitos, folhelhos e siltitos) e Corumbataí (siltitos, folhelhos, arenitos e calcários) e grupo são Bento, com as formações Botucatu e Piramboia (arenitos, argilitos e conglomerados). 
Essas rochas sedimentares e seus produtos de intemperismo formam o substrato da ārea, assim como, as intrusivas bāsicas, conforme INSTITUTO GEOGRĀFICO E GEOLōgICO (1974).

As intrusivas bāsicas ocorrem infiltradas entre os sedimentos, formando "sills", lacōlitos e batólitos, que formam as elevações nesta ārea, modestas mas que sé sobressaem na paisagem.

Pesquisas de PENTEADO (1968), ligadas à geomorfologia da região, indicam a ocorrência generalizada de cascalheiras que marcam as descontinuidades litológicas sob depósitos recentes.

\subsubsection{Solos}

Dentre as unidades de mapeamento classificadas e descritas por OLIVEIRA et alii (1982) na quádricula de Araras, foram escolhidas aquelas que apresentavam interesse para esta pesquisa e que são os Latossolos Argilosos que predominam nesta àrea.

Esses solos jā foram objeto de estudo anterior, relacionado à densitometria ótica em fotografias aéreas e caracteristicas das suas cores (DONZELI, 1979). Foram reestudados neste trabalho considerando-se a grande dificuldade de separação desses solos pelos aspectos externos da paisagem, tanto em trabalho de campo como por fotointerpretação preliminar para posterior apoio de campo, além da grande extensão territorial que ocupam em São Paulo. 
Três classes de Latossolos foram identificadas por OLIVEIRA et alii (1982) na quadrícula de Araras: Latossolos Roxos, Vermelho-Amarelos e Vermelho Escuros. Na ārea estudada predominam unidades de mapeamento provenientes de subdivisões destas, ou subcategorias, com base no carater álico, tipo do horizonte $A$, textura do horizonte $B$ e saturação em bases, sendo selecionadas nesta pesquisa, como categorias mais individualizadas e que receberam nomes regionais, como se segue:

a) Latossolos Roxos- São originários de materiais intemperizados de rochas básicas (basalto e diabásio) apresentando, consequentemente, elevados teores de hematita e cores mais vermelhas que $3,5 Y R$ e relação valor/croma igual ou inferior a $3,5 / 5$.

Entre os Latossolos Roxos selecionou-se a unidade" B.arão Geraldo" (LRd), correspondente ao Latossolo Roxo distrófico.

b) Latossolos Vermelho Escuros (argilosos). Os Latossolos Vermelho Escuros de textura argilosa, ocorrentes nesta área, são provenientes do intemperismo e retrabalhamento de sedimentos finos: argilitos e siltitos com variada contribuição de rochas básicas. As cores com matiz mais vermelho que $4 Y R$ e valor igual ou inferior a 4 (quatro). Os teores de ferro total superiores a 9 e inferiores a $18 \%$.

Entre esses solos selecionou-se a unidade "Limeira" (LE.1), correspondente ao Latossolo Vermelho Escuro textura argilosa. 
c) Latossolos Vermelho-Amarelos (argilosos) 0 material de origem destes solos são sedimentos argilosos retrabalhados, relacionados às rochas dos Grupos Tubarão e Passa-Dois. São solos que apresentam cores mais amarelas que $3,5 Y R$ e relação valor/croma superior a $4 / 4$. Os teores de ferro total são inferiores a $9 \%$, apresentando também o carater ālico ou saturação com aluminio superior a $50 \%$.

Para representar esses solos selecionou-se a Unidade Mato Dentro (LV.5), correspondente ao Latossolo Vermelho-Amarelo textura argilosa.

3.1.3.1. Unidade Barão Geraldo (LRd)

A classificação segundo OLIVEIRA et alii(1982)

$\bar{e}$ a seguinte:

- Latossolo Roxo epieutrófico ou distrófico, A moderado, textura muito argilosa ou argilosa, relevo suave ondulado.

- Typic Haplorthox e Typic Acrorthox (USA).

Essa unidade apresenta as seguintes caracteristicas diferenciais de outras unidades:

1) Textura muito argilosa ou argilosa;

2) Teor de areia grossa inferior a $20 \%$;

3) Saturação com bases inferior a $50 \%$ e soma de bases inferior a 1,5 e.mg/100g de T.F.S.A.;

4) Matiz do horizonte $B 2$ mais vermelho que $3,5 Y R$ com relação valor/croma igual ou inferior a $3 / 5$;

5) Horizonte B2 sem estrutura ou com estrutura subangular fraca e com consistência muito friāvel. 
As características morfológicas do horizonte $A$

são as seguintes:

1) Presença de horizonte superficial Ap devido à grande utilização agrícola desses solos;

2) Espessura do A raramente superior a $30 \mathrm{~cm}$;

3) Cor centrada no matiz 2,5. YR com relação valor/croma $3 / 4$ ou $3 / 3$;

4) Textura argilosa e consistência ligeiramente dura; friāvel, plāstica e pegajosa;

5) Estrutura mal definida - blocos médios e pequenos sem superfície de fraqueza definida.

As unidades afins à unidade Barão Geraldo são:

- LRe (Ribeirão Preto), que apresenta o carater eutrōfico como caracteristica diferencial. Unidade TE (Terra Roxa Estruturada, que apresenta como principal característica diferencial o carater eutrófico e a estrutura bem desenvolvida. Tambēm a unidade LE.l (Limeira) apresenta características afins ao LRd, diferindo desta pelo teor de ferro total: $\mathrm{Fe}_{2} \mathrm{O}_{3}<18 \%$; e cores mais escuras que $2,5 \mathrm{YR} 3 / 4$.

3.1.3.2. Unidade Limeira (LE.1)

A classificação, segundo OLIVEIRA et alii,

(1982), è a seguinte:

- Latossolo Vermelho Escuro distrófico ou ālico, A moderado, textura argilosa ou muito argilosa, relevo aplainado ou suave ondulado. 
- Typic Haplorthox (USA).

Essa unidade apresenta, além das caracterīsticas diferenciais dos Latossolos Vermelho Escuros,as seguintes características:

1) Horizonte A moderado;

2) Textura argilosa ou muito argilosa ao longo do perfil;

.3) Horizonte BI com estrutura sub angular fraca ou moderada e horizonte B2 sem èstrutura ou com estrutura subangular fraca;

4) Carater distrófico ou àlico.

As características morfológicas do horizonte A são:

1) Presença de horizontes $A p$ ou $A_{1}$ e $A_{3}$;

2) Espessura do A raramente superior a $40 \mathrm{~cm}$;

3) Cor mais comum do $A_{1}$ ou Ap é 3,5YR 3/4;

4) Textura argilosa ou muito argilosa e consistência da amostra friável quando úmida e plástica e pegajosa quando moIhada;

5) Estrutura mal definida ou degradada no $A p$, sendo comum a presença de fragmentos pequenos e médios.

$$
\begin{aligned}
& \text { 3.1.3.3. Unidade Mato Dentro (LV.5) } \\
& \text { Segundo OLIVEIRA et alii (1982), é classificada }
\end{aligned}
$$

como:

- Latossolo Vermelho = Amarelo àlico, A moderado, textura argilosa, relevo suave ondulado ou aplainado.

- Typic Haplorthox (USA). 
Além das características comuns aos Latossolos Vermelho-Amarelos, apresentam as seguintes características:

1) Horizonte A moderado;

2) Textura argilosa ou muito argilosa (Hor. B);

3) Carater àlico ou distrófico;

4 ) Estrutura fraca ou $B_{2}$ sem estrutura.

As caracteristicas morfológicas do horizonte $A$ são:

1) Presença de horizontes $A p$ ou $A_{1}$ e $A_{3}$;

2) Espessura do A raramente superior a $50 \mathrm{~cm}$;

3) Cor mais comum é bruno-avermelhado-escura centrada no matiz $5 Y R$ ou bruno-escura com matiz 7,5YR;

4) Textura mais comum é barrenta, podendo ser argilosa;

5) Estrutura mal definida por serem áreas agricultadas, predominando fragmentos duros com $2-3 \mathrm{~cm}$ de diāmetro.

3.1.4. Características Analiticas das Unidades de So10

São apresentados na Tabela 3 , resultados comparativos de características analíticas para as três unidades descritas, considerando-se apenas o valor médio, o minimo absoluto e o máximo absoluto de características físico-químicas referentes à camada superficial.

Pode-se verificar por essa tabela, assim como pelas demais características descritas, que a cor e o teor de ferro total podem ser consideradas como importantes características diferenciais para essas unidades de solo. 
Tabela 3 - Média $(\bar{x})$ e valores mīnimo e māximo de algumas características da camada superficial dos solos estudados. OLIVEIRA et alii (1982).

\begin{tabular}{|c|c|c|c|c|c|c|c|c|c|}
\hline \multirow{2}{*}{ Caracteristicas } & \multicolumn{3}{|c|}{ LRd } & \multicolumn{3}{|c|}{ LE. 1} & \multicolumn{3}{|c|}{ LV.5 } \\
\hline & $\bar{x}$ & $\min$ & $\max$ & $\bar{x}$ & $\min$ & $\max$ & $\bar{x}$ & $\min$ & $m x$ \\
\hline $\mathrm{pH}$ & 5,1 & 4,1 & 6,2 & 5,1 & 4,0 & 6,5 & 5,0 & 4,0 & 5,0 \\
\hline$C(1)$ & 1,7 & 0,7 & 2,3 & 1,7 & 1,4 & 2,3 & 1,4 & 0,4 & 2,9 \\
\hline$S(2)$ & 3,6 & 0,3 & 9,7 & 4,1 & 0,4 & 11,2 & 2,6 & 0,0 & 7,7 \\
\hline$A 1^{3+}(2)$ & 0,4 & 0,0 & 1,5 & 0,6 & 0,0 & 2,0 & 0,7 & 0,0 & 2,4 \\
\hline $\operatorname{cTC}(3)$ & 14,4 & 2,9 & 20,5 & 10,2 & 11,6 & 21,5 & 19,6 & 12,2 & 32,6 \\
\hline$V(1)$ & 39,6 & 6,2 & 84,3 & 45,0 & 7,8 & 94,9 & 31,0 & 0,9 & 74,4 \\
\hline $\mathrm{RC}(3)$ & 7,2 & 1,9 & 17,3 & 8,5 & 3,0 & 18,4 & 8,6 & 3,3 & 18,4 \\
\hline$m(1)$ & 24,0 & 0,0 & 68,0 & 26,0 & 0,0 & 71,0 & 47,0 & 0,0 & 96,0 \\
\hline Argila (1) & 57,0 & 29,0 & 74,0 & 53,0 & 36,0 & 75,0 & 38,0 & 24,0 & 57,0 \\
\hline Limo (1) & 0,8 & 2,0 & 13,0 & 8,0 & 2,0 & 15,0 & 5,0 & 1,0 & 9,0 \\
\hline Areia fina (1) & 24,0 & 15,0 & 45,0 & 25,0 & 10,0 & 37,0 & 40,0 & 22,0 & 53,0 \\
\hline Areia Grossa & 11,0 & 3,0 & 24,0 & 14,0 & 2,0 & 32,0 & 18,0 & 6,0 & 38,0 \\
\hline $\mathrm{Fe}_{2} \mathrm{O}_{3}$ & 21,0 & 17,0 & 29,0 & 12,0 & 5,0 & 18,0 & $\overline{-}$ & - & - \\
\hline
\end{tabular}

(C) Carbono, (S) Soma de bases, $\left(A 7^{3+}\right)$ Alumínio Trocāvel

(CTC) Capacidade de Troca de Cations, (V) Saturação em bases

(RC) Retenção de Cations, (m) Saturação em aluminnio

$\left(\mathrm{Fe}_{2} \mathrm{O}_{3}\right)$ Ferro Total. (1) \%, (2) e.mg/100g de TFSA, (3) e.mg/100g de argila. 
3.1.5. Relações solos/geomorfologia

Os solos descritos apresentam grande homogeneidade em características da paisagem, sendo muito difícil estabelecer critérios geomorfológicos a eles relacionados.

Uma pesquisa de critérios de fotointerpretação envolvendo essas três unidades de solo mostrou grande semeThança nas características da drenagem superficial dos mesmos (DONZELI*).

Foram analisadas algumas características das redes de drenagem, com determinação de indices quantitativos para a densidade de drenagem ( $D d$ ), Frequéncia de Calhas (FC) e Razão de Textura (Rt), características preconizadas por FRANÇA (1968). Como se pode observar na Fig.5 e nas Tabelas 4 e 5 , os indices estabelecidos para as unidades LRd (Barão Geraldo), LE.1 (Limeira) e LV.5 (Mato Dentro), apresentam valores proximos, sem diferença estatística significativa.

\section{$3.1 .6 .01 \mathrm{ima}$}

Os dados de valores médios de temperatura do ar e da precipitação pluviométrica das localidades de Limeira e Araras no Estado de São Paulo, limítrofes da área estudada,podem ser visualizados na Tabela 6 , segundo a estação do ano.

* DONZELI, P.L. - Critérios de fotointerpretação aplicados a solos da quadrícula de Campinas - S.P.

- Relatōrio apresentado ao CNPq. Campinas, Instituto Agronōmico, 60p. (mimeografado). 

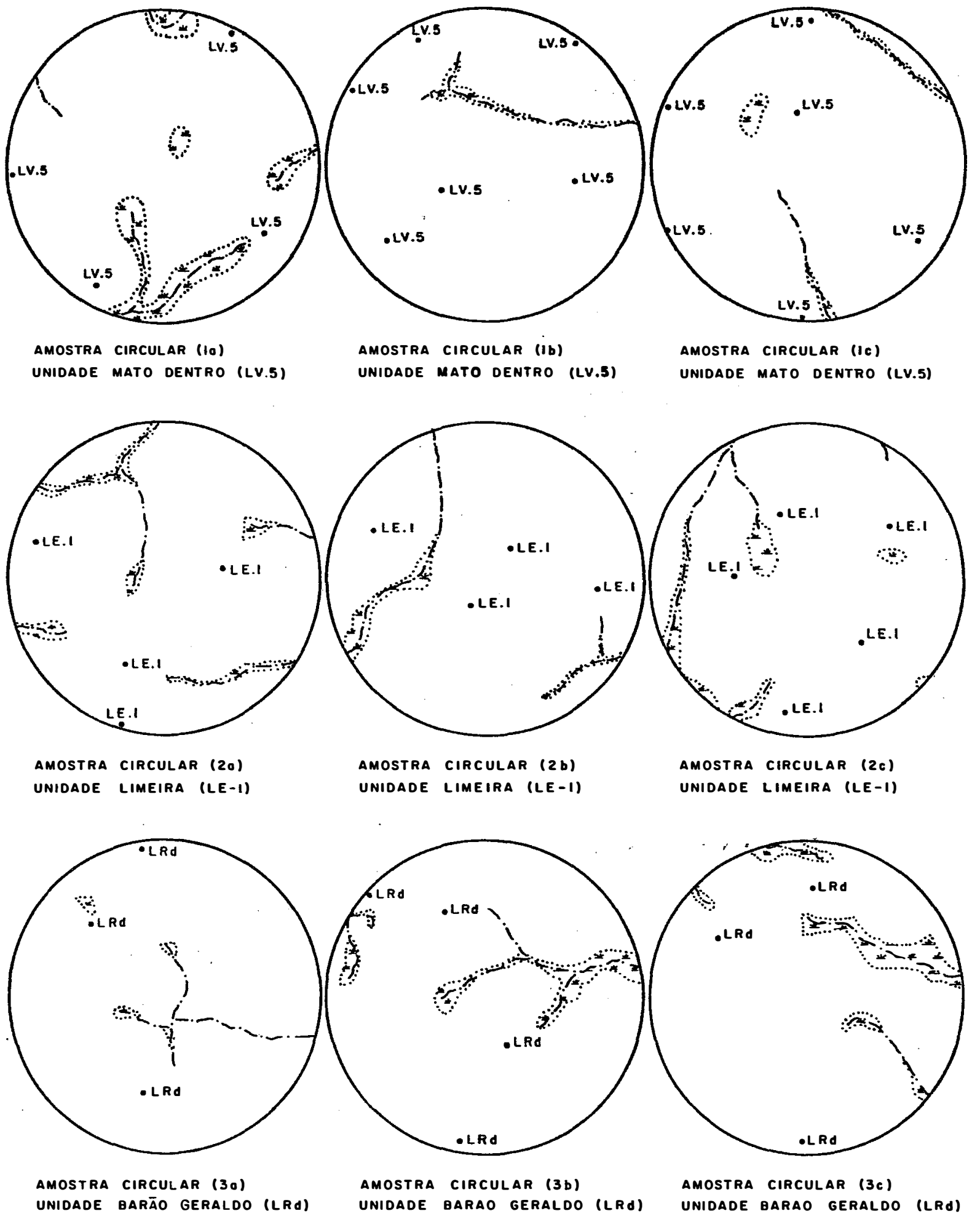

Fig. 6 - Amostras circulares representativas das redes de drenagem dos solos estudados e pontuações referentes à malha de pontos de prospecção do levantamento pedológico. Escala 1:50.000. 
Tabela 4 - Características quantitativas do padrão de drenagem das amostras circulares das três anidades de solo estudadas.

\begin{tabular}{|c|c|c|c|c|}
\hline \multirow{2}{*}{ Unidades } & \multirow{2}{*}{ Amos tras } & $\begin{array}{l}\text { Densidade de } \\
\text { Drenagem (Dd) }\end{array}$ & $\begin{array}{l}\text { Frequência } \\
\text { Calhas (FC) }\end{array}$ & $\begin{array}{l}\text { Razão de } \\
\text { Textura. (Rt) }\end{array}$ \\
\hline & & $\begin{array}{l}\text { Valor - média } \\
s^{\prime}(\hat{m})^{*}\end{array}$ & $\begin{array}{l}\text { Valor - média } \\
\qquad s(\hat{m})\end{array}$ & $\begin{array}{l}\text { Valor - média } \\
\qquad \mathrm{s}(\overline{\mathrm{m}})\end{array}$ \\
\hline & la & 0,60 & 1,20 & 0,76 \\
\hline Mato Dentro & $1 \mathrm{~b}$ & 0,40 & 0,60 & 0,38 \\
\hline \multirow[t]{3}{*}{ (LV.5) } & 1c & $0,50 \quad 0,50$ & $0,60 \quad 0,80$ & $0,38 \quad 0,51$ \\
\hline & & $s(\overline{\mathrm{m}})= \pm 0,06$ & $s(\bar{m})= \pm 0,20$ & $s(\bar{m})= \pm 0,48$ \\
\hline & $2 a$ & 0,90 & 1,20 & 0,80 \\
\hline Limeira & $2 b$ & 0,65 & 0,80 & 0,51 \\
\hline \multirow[t]{3}{*}{$(L E, l), \ldots$} & $2 c$ & $0,75 \quad 0,77$ & $0,80 \quad 0,93$ & $0,51 \quad 0,61$ \\
\hline & & $s(\overline{\mathrm{m}})= \pm 0,07$ & $s(\bar{m})= \pm 0,13$ & $s(\hat{m})= \pm 0,08$ \\
\hline & $3 a$ & 0,55 & 0,80 & 0,51 \\
\hline Barão Geraldo & $03 b$ & 0,75 & 1,20 & 0,76 \\
\hline \multirow[t]{2}{*}{ (LRd) } & $3 c$ & $0,75 \quad 0,68$ & $1,20 \quad 1,07$ & $0,76 \quad 0,68$ \\
\hline & & $s(\bar{m})= \pm 0,06$ & $s(\overline{\mathrm{m}})= \pm 0,08$ & $s(\hat{m})= \pm 0,08$ \\
\hline
\end{tabular}


Tabela 5 - Valores (D) do teste de Duncan (D.M.S.), para comparáção de mêdias das características quantitativas dos solos estudados.

\begin{tabular}{|c|c|c|c|}
\hline Caracterīsticas & $\begin{array}{l}\text { Valores de } D n^{*} \\
\text { ao nivel de } 1 \%\end{array}$ & $\begin{array}{l}\text { Mêdias (contrastes) } \\
\text { ao nivel de } i \%\end{array}$ & Solos \\
\hline $\begin{array}{l}\text { Densidade de } \\
\text { drenagem }\end{array}$ & $\begin{array}{l}D_{3}=1,14 \\
D_{2}=1,08\end{array}$ & $\begin{array}{l}M_{1}=0,77 \\
M_{2}=0,68 \\
M_{3}=0,50\end{array} \mid$. & $\begin{array}{l}\text { LE. } 1 \\
\text { LRd } \\
\text { LV. } 5\end{array}$ \\
\hline $\begin{array}{l}\text { Frequēncia } \\
\text { Calhas (Fc) }\end{array}$ & $\begin{array}{l}D_{3}=5,41 \\
D_{2}=5,14\end{array}$ & $\begin{array}{l}M_{1}=1,07 \\
M_{2}=0,93 \\
M_{3}=0,80\end{array}$ & $\begin{array}{l}\text { LRd } \\
\text { LE. } 1 \\
\text { LV. } 5\end{array}$ \\
\hline $\begin{array}{l}\text { Razão de } \\
\text { Textura (Rt) }\end{array}$ & $\begin{aligned} & D_{3}=3,55 \\
& D_{2}=3,37 \\
& \ldots\end{aligned}$ & $\begin{array}{l}M_{1}=0,68 \\
M_{2}=0,61 \\
M_{3}=0,50\end{array}$ & $\begin{array}{l}\text { LRd } \\
\text { LE. } 1 \\
\text { LV. } 5\end{array}$ \\
\hline
\end{tabular}

$*_{n}=$ No de mëdias a comparar.

* As médias unidas por barra não diferem significativamente ao níve 1 1\% de probabilidade. 
Tabela 6 - Médias de temperatura e precipitação pluviométri-r ca, por estação do ano, das localidades de Limeira e Araras - S.P. (1)

\begin{tabular}{lccc}
\hline Estação do Ano & Meses & Temperatura Precipitação \\
\hline $\begin{array}{l}\text { Primavera } \\
\text { Verão }\end{array}$ & $\begin{array}{r}\text { Set. Out. Nov. } \\
(2)\end{array}$ & 20,4 & 330 \\
Dez: Jan. Fev. & 22,0 & 674 \\
Outuno & Mar. Abr. Mai. & 19,9 & 271 \\
Inverno & $(3)$ & 17,0 & 95 \\
\hline Ano & Jun. Jul. Ago. & 19,8 & 1370 \\
\hline
\end{tabular}

(1) Adaptado de OLIVEIRA et alii (1982).

(2) Mès mais quente, temperatura mēdia $22,2^{\circ} \mathrm{C}$.

(3) Mès mais frio, temepratura mëdia $16,1^{\circ} \mathrm{C}$. 
A distribuição das chuvas mostra um regime tīpico de zonas tropicais de baixa altitude, caracterizado por um verão chuvoso e inverno sêco. A temperatura do ar caracteriza as estações do ano, com valores extremos no verão e inverno. 0s dados apresentados permitem identificar o clima da ārea como tipo Cwa do sistema Küppen, subtropical úmido.

Segundo SETZER (1966), as características desse clima são: precipitação pluviométrica média anual superior a $1.000 \mathrm{~mm}$, temperatura média do més mais frio inferior a $180 \mathrm{C}$ e a do mès mais quente, superior a $220 \mathrm{C}$.

3.1.7. Vegetação Natural e Uso da Terra

$\mathrm{Na}$ àrea estudada, devido às grandes possibili-

dades oferecidas pelas características do clima e solos, para utilização agrícola, hoje não mais existe a vegetação natural original, ao que tudo indica constituida por mata subperenifólia. CHIARINI e COELHO (1972) s.: OLIVEIRA et alii (1982).

0 uso da terra nessa área é representado exclusivamente pela cultura da cana-de-açucar, desenvolvida em função das mencionadas possibilidades e do grande parque agro -industrial para produção de açucar e álcool que se instaloú na região.

3.2. Equipamentos

3.2.1. Espectrōmetro fotoacústico

0 equipamento usado para determinação dos es pectros óticos em laboratório foi o espectrōmetro fotoacústi- 
co, montado pela divisão de sistemas sensores do INPE em São José dos Campos, cujo esquema de funcionamento é descrito por ROSENCWAIG (1977). Fig. 3 .

- 0 espectro ótico obtido nesse aparelho ē dinamicamente compensado para distribuição espectral da energia de uma fonte de luz de xenōnio e normalizado em relação ao espectro do preto absoluto. Segundo ROSENCWAIG (1977), esse procedimento parece assegurar a reprodutividade e comparabilidade em relação a espectros de mesmos materiais, obtidos por outras técnicas.

Foram obtidos espectros óticos de absorção na faixa de 450-900 nm, identica à faixa de sensibilidade dos filmes infravermelhos coloridos utilizados na pesquisa.

\subsubsection{Densitômetros}

Para medidas de densidade ōtica de imagens homōlogas em transparēncias coloridas normais e infravermeIhas foram utilizados os densitómetros de transmissäo Mc Beth TD 504 para medidas de densidade difusa, equipado com filtros Status $A$ (vermelho, verde, azul e visual), onde 0 feixe de luz transmitido è medido segundo uma tolerāncia angular.

Nas medidas de densidade ótica das cores contidas na carta de cores de solos de Munsell e amostras de solos, utilizou-se o densitōmetro de reflexão difusa Mc Beth RD 519, equipado com filtros Status D (vermelho, verde, azul e visual). Esses aparelhos foram calibrados para produ- 
zir leituras comparáveis, desde que usados para controle de qualidade de produtos fotogrāficos, visando a fidelidade de reprodução em relação aos originais.

\subsubsection{Estereoscōpio}

Utilizou-se o estereoscópio de espelho WILD ST-4, equipado com binocular de aumento $3 X$, com finalidade de seleção de glebas para estudo.

\subsection{Material aerofotogrāfico}

Utilizou-se o material da cobertura aerofotogrāfica da missão experimental de pesquisa no 96, executada pela NaSA em 1969, na região de Campinas, Estado de São Pau10, indicada na Fig.4. Cada ārea foi sobrevoada em várias linhas, e dentro dessas linhas a aeronave efetuou uma ou mais passagens. As características do material utilizado estão especificadas na Tabela 7 , conforme INPE (1975).

Para os trabalhos de campo foram utilizadas aerofotografias pancromáticas da cobertura aerofotogramétrica do Estado de São Paulo, executada pela TERRAfoto S/A, para o Instituto Brasileiro do Café, em escala aproximada $1: 25.000$, ano de 1971 .

3.4. Seleção dás āreas de estudo.

3.4.1. Fatoires que influenciaram a escolha da àrea. 


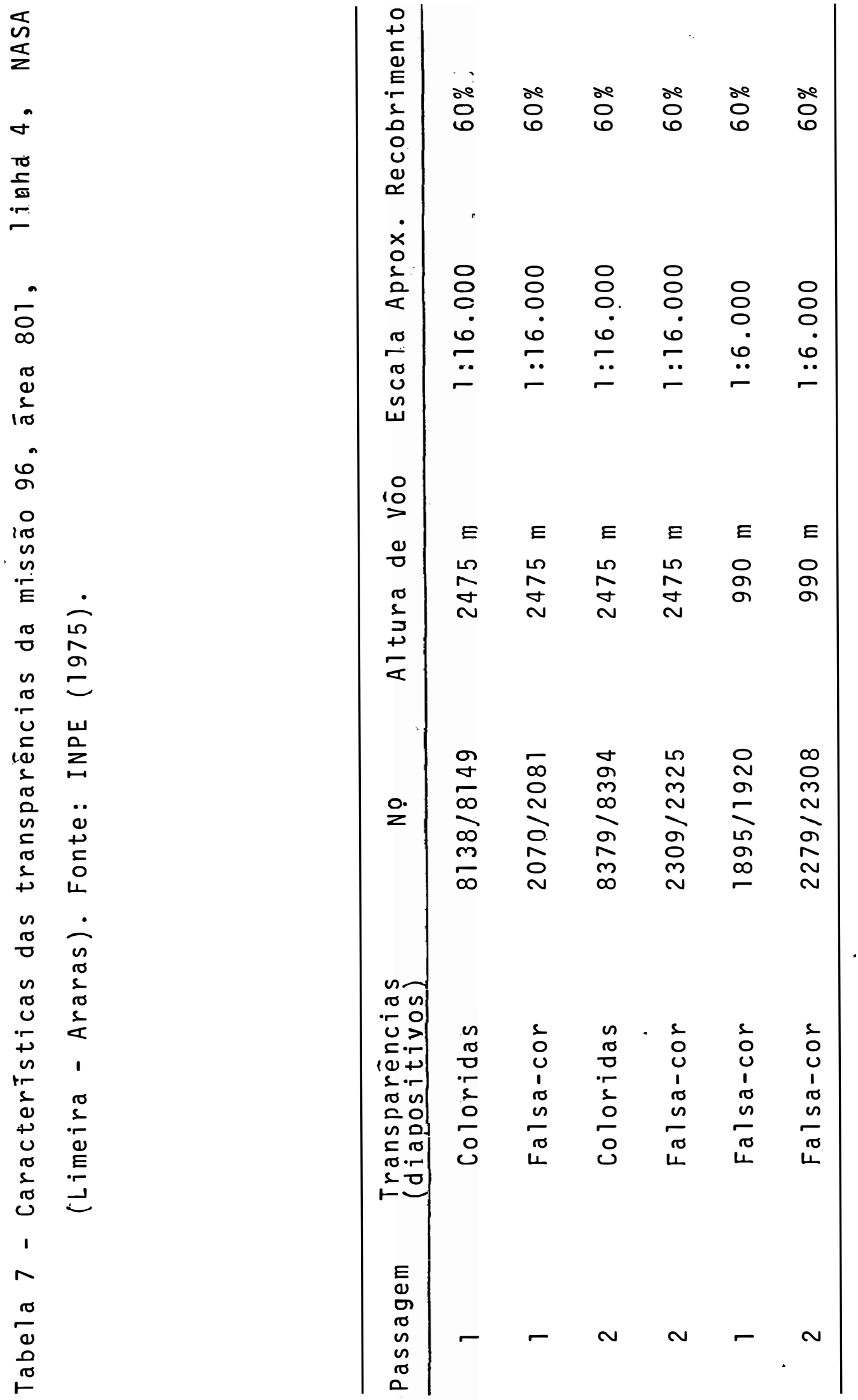


a) Existēncia de um mapa de solos em nĩvel de semidetalhe, executado com base numa malha de pontos de prosDecção de campo com suficiente densidade, OLIVEIRA et alil $(1982)$

b) Ocorrēncia p̣redominante nesta ārea de trēs latossolos argilosos, cujos padröes fisiográficos são muito semelhantes e os padrões espectrais pouco conhecidos; ocupando significativa ārea de ocorrēncia no Estado de São Paulo.

c) Existēncia de cobertura aerofotogrāfica multissensorial para desenvolvimento da pesquisa.

d) Area sob cultivo da cana-de-açucar, qué apresenta a caracteristica de homogeneidade de cobertura vegetal e glebas de solos expostos na entressafra, de grande interesse nesta pesquisa.

e) Existéncia de pesquisa anterior, com apresentação parcial de dados densitométricos, correlacionados neste trabalho a outras características (DONZELI, 1979).

\subsubsection{Métodos utilizados na seleção das glebas}

As glebas para añ̄ise densitométrica foram selecionadas em transparēncias coloridas infravermelhas em escala 1:6.0no, que proporcionaram boa percepção de detalhes do terreno, de grande valia para escolha das glebas com grande homogeneidade. de características, tais como, aspectos do preparo do solo, presença de cobertura morta, etc. 
o critério utilizado para seleção das glebas levou em consideração os fatores que influenciam nos registros de tonalidade em aerofotografias, com base na revisão de 1 iteratura RICCI 'e PETRI (1965), STEINER e HAEFNER (1965), ESTES e SIMONETT (1975), RAY (1963), LUEDER (1959), PIECH e WALKER (1974).

Alguns cuidados foram tomados com a finalidade de minimizar a influéncia de variāveis que deveriam ser fixadas na pesquisa, tais como:

a) Uso de fotos em grandes escalas;

b) Seleção de glebas dentro da ārea ūtil das aerofotos;

c) Glebas localizadas em apenas duas fajxas de vōo.

Foram selecionadas para medição 40 glebas. de solos expostos:em condições homogēneas, das quais foram aproveitadas 18, em função da rede de pontos de prospecção do levantamento pedológico semidetalhado da região.

As 18 glebas selecionadas, com tamanho variāvel de 1,0 a 3,0 ha, em locais previamente amostrados, são 
representadas por duas faixas de cobertura em escala 1:16.000. Dentro das glebas foram coletadas amostras do horizonte superficial $(0-20 \mathrm{~cm})$, para anālises físicas e químicas.

Para os trabalhos de campo e coleta de amostras nos locais selecionados, foram transferidas as informações das transparēncias coloridas para cópias em papel preto-ebranco de aerofotografias em escala 1:25.000.

\subsection{Anālise densitomētrica}

3.5.1. Dados de densidade ótica - Transmitância ou Reflectância relativa

os dados de densidade ótica em imagens coloridas normais è infravermelhas em escala $1: 16.000$ foram obtidos com densitōmetro Mc Beth TD 504 de transmissão difusa e em amostras de solos e carta de cores de Munsell, com densitómetro Ṃc Beth RD 519 de reflexão difusa, conforme descrito em DONZELI (1979).

Os dados de densidade ótica foram aproveitados nesta pesquisa, sendo transformados em transmitância ou reflectāncia com base na equação de SCARPACE e FRIEDERICHS (1978).

$$
D\left(\lambda_{a}\right)=\log \frac{1}{T(\lambda a)} \text { sendo } T(\lambda a)=\frac{1}{\operatorname{anti} \log D(\lambda a)}
$$

onde $T$ é a transmitancia ou reflectāncia relativa aos fluxos de luz incidente e transmitido, quando utilizado densitōmetro de transmissão ou reflexão: 
0 valor T é relativo à função de transmitāncia do filtro usado no densitōmetro e à sensibilidade relativa do densitōmetro ao fluxo de luz; $\lambda$ a representa uma região espectral, caracterizada pela transmitancia do filtro que seleciona o fluxo de luz incidente; e $D$ é a densidade ótica, que è uma função logarítmica.

3.6. Anālise de espectroscopia fotoacústica,

3.6.1. Preparo das amostras

Para o preparo das amostras das quais foram obtidos os espectros fotoacústicos, foram elas tamizadas em peneira de malha de $1 \mathrm{~mm}$ de diāmetro, seguindo a recomendação de MONTGOMERY et alii (1976) para a anālise espectrométrica, embora tenha sido utilizado outro tipo de aparelho.

Optou-se por essa padronização porque foi a mesma utilizada para a anālise densitométrica da cor do solo. As amostras foram secadas à temperatura ambiente, em igual período de tempo, obtendo-se a TFSA (terra fina sèca ao ar).

3.6.2. Espectros de absorção

As amostras foram colocadas em um recipiente, uma por vez, numa célula fechada do aparelho para obtenção dos espectros fotoacústicos que, de acordo com o princípio de funcionamento do aparelho, ROSENCWAIG (1977), correspondem aos verdadeiros espectros de absorção óticos da amostra.

os espectros foram obtidos na faixa de compri- 
mento de onda de 450-900 nm.

\subsubsection{Obtenção de dados}

A partir dos espectros de absorção foram determinadas as intensidades relativas de absortāncia para cada intervalo de $50 \mathrm{~nm}$, a partir de 450 até $900 \mathrm{~nm}$. Por integra- ção das áreas sob as curvas, que representam as intensidades do sinal fotoacūstico em função do comprimento de onda, foram obtidos os valores relativos proporcionais à energia absorvida, uma vez que apenas a luz absorvida ē convertida em som.

Os valores de intensidades relativas, proporcionais à energia absorvida em cada intervalo de comprimento de onda, foram transformados em porcentagens em função do total de energia absorvida. A partir desses valores foram calculados os valores dé intensidades relativas proporcionais a energia refletida, desde que:

$$
\text { energia absorvida + refletida + transmitida }=1
$$

sendo a transmitāncia nas amostras $=0$ 
3.7. Anālise das características físicas e químicas:dos solos. 3.7 .1 . Cor do solo

Sendo a cor uma característica influenciada por fatores psico-fisiológicos, procurou-se eliminar a subjetividade da determinação da cor das amostras de solo, quando comparadas visualmente às cartas de cores.

DONZELI (1979) efetuou determinações das cores Munsell-densitométricas das amostras de solos, seguindo metodologia proposta por RIB (1968), com base em ābacos e equações de regressão desenvolvidas por aquele autor.

Esse procedimento introduz erros nas determinações, em função de condições inerentes à pesquisa realizada, onde se incluem a especificação de aparelhos e técnicas metodológicas. No entanto, admite-se que os desvios são proporcionais às medidas reais, relacionando-se com estas atravēs de uma constante, o que se justifica pela obtenção de valores altamente correlacionados às medidas densitométricas e, portanto, independentes de fatores psico-fisiológicos.

No presente trabalho, procurou-se desenvolver equações de regressão especĩficas para as condições usadas na pesquisa, onde se incluem como principais fatores os : densitōmetros e transmitância dos filtros, 0 que minimiza os desvios; restando ainda a influência de fatores relativos as técnicas de preparo das amostras.

Assim sendo, foram aproveitados os valores densitométricos obtidos para as mesmas amostras, segundo a 
metodologia descrita por DONZELI (1979).

Essa metodologia descreve aspectos de preparo da amostra para anālise densitométrica com densitōmetro de reflexão difusa Mc Beth RD 519, com utilização dos filtros Status D (vermelho, verde, azul e visual).

Para estabelecimento das equações de regressão foram efetuadas as leituras densitométricas da carta de cores de Munsell, usada para determinação de cores de solos, incluindo os matizes vermelhos e amarelos (10R, 2,5YR, 5, OYR, $7,5 Y R, 10 Y R, 2,5 Y$ e $5,0 Y)$.

Posteriormente, com base em indicações de RIB (1968), foram calculadas as variáveis geradoras das características da cor de Munsell, para as leituras densitométricas da carta de cores, com modificações. As modificações introduzidas referem-se à transformação dos dados de densidade ótica em reflectância relativa, cap..3-:(3.5); e cálculo da variável geradora do matiz, segundo modificação proposta por KOFFLER (1982), considerando-se os valores RR maiores ou menores que a unidade $(R R \gtrless 1)$. A justificativa para substituição de valores de densidade por valores de reflectāncia relativa é que a densidade é uma função logarítmica da reflectāncia ou transmitância relativa, sendo que o logarítmo das variāveis de densidade apresentaram altas correlações lineares com as ca-. racterísticas das cores.

As variāveis consideradas foram as seguintes: $R=$ variável geradora do valor Munsell/densitométrico. 
$R=V$

sendo, $V=$ reflectāncia relativa com filtro visual $\times 1000$

$\mathrm{RR}=$ variāvel geradora do matiz Munsell/densitométrico

$R R=\frac{A}{B}$, sendo $R R \gtrless 1$

onde, $A=(T-I)$ e $B=(I-t)$, sendo $T$, maior valor de reflectāncia relativa; $t$, menor valor e I, valor intermediārio de reflectãncia relativa.

RRR = Variāvè geradora do croma Munsell/densitométrico

$R R R=\frac{T-t}{t}$

As equações de regressão calculadas são as

seguintes:

$$
\text { Matiz }=20,0-10,0 \times \ldots \ldots(1)
$$

sendo, $x=\log R R=\log \frac{A}{B}=\log \frac{V m-V d}{V d-A z}$

onde, $V m=$ Reflectāncia relativa com filtro vermelho $\times 1000$

$V d=$ Reflectāncia relativa com filtro verde $\times 1000$.

$A z=$ Reflectāncia relativa com filtro azul $\times 1000$

$$
\text { Valor }=2,40+0,01 \times \ldots .(2)
$$

sendo, $\dot{x}=R=V$

$$
\text { Croma }=1,00+1,30 x \ldots \ldots(3)
$$

sendo, $x=R R R=\frac{T^{*}-t}{t}=\frac{V m-A z}{A z}$. 
Como as variāveis geradoras das características das cores foram calculadas apenas para os matizes vermelhos e amarelos, o filtro vermelho produziu sempre a maior leitura de reflectāncia relativa e o filtro azul, sempre a menor leitura.

Com base nas equações (1), (2) e (3) foram determinadas as características das cores das amostras de solos.

\subsubsection{Oxidos de ferro livres}

A determinação dos óxidos de ferro livres, como hematita e goetita, que não estão presos às estruturas cristalinas dos minerais de argila, foi feita pelo método do citrato, bicarbonato e ditionito de sōdio (CDB), colorimetricamente pela orto-fenantrolina, segundo JACKSON (1969).

\subsubsection{Matéria orgânica}

o princípio do método usádo na determinação da matéria orgānica do solo foi a sua oxidação por dicromato de sōdio em presença de ācido sulfúrico e determinação colorimétrica da cor verde devida ao ín crómico proveniente da reação de oxidação.

Os valores obtidos são de matéria orgānica em $\%$ de volume de T.F.S.A., conforme VAN RAIJ e ZULLO (1977).

\subsubsection{Anālise granulométrica}

A composição granulométrica foi obtida pelo método da pipeta, modificado por GROHMANN e VAN RAIJ (1974) com uso do agitador de Wagner, dispersão por hexametafosfato 
de sōdio e $\mathrm{NaOH}$. A escala de textura è a de Atterberg e a classificação textural, de MEDINA e GROHMANN (1962).

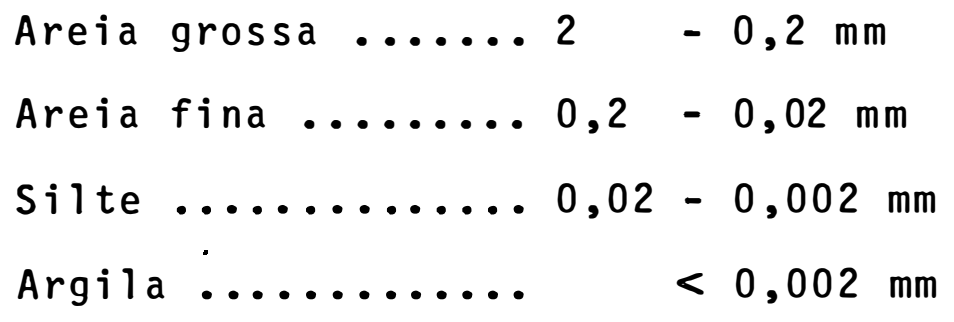

3.8. Anālise Estatística.

Apōs a obtenção dos dados, de acordo com os métodos descritos, ou seja, dados de reflectāncia do espectro fotoacūstico e refiectāncia densitométrica relativa em amostras de solos; transmitância relativa em transparências aerofotográficas e dados de anālises fĩsicas e quîmicas, seguiramse os seguintes procedimentos.

Como primeiro passo foram. efetuados cálculos para obtenção de indices relativos às razões espectrais do espectro fotoacústico e sobre dados de fotografias aéreas.

Esse procedimento foi baseado, principalmente, na eliminação da variabilidade dos dados devida amplitude das curvas de reflectāncia ou transmitāncia, em proporções constantes a todas regiões do espectro. Assim, foi possivel julgar paralelamente a significância desses dados em relação às demais variāiveis estudadas.

Em seguida, procedeu-se à anālise de variância para verificar a separabilidade espectral entre solos e sua significância. 
Foram tambēm efetuadas añāises de regressão simples e mūltipla, onde os dados es bectrais foram considerados como variāveis dependentes e as propriedades físicas e quỉmicas dos solos, como variāveis independentes.

Para a seleção das variāveis da regressao múltipla utilizou-se o processo descrito por DRAPER e SMITH (1966), que requer o exame da significância das variáveis incorporadas ao modelo, em estāgios subsequentes. com utilização dos coeficientes de correlação simples e parcial. A seleção começa com uma equação de regressão simples, inserindo gradativamente as demais variáveis. A ordem de inserção das variáveis é determinada usando-se o coeficiente de correlação parcial como uma medida da importāncia das variāveis que devam compor a equação.

Primeiramente, com base em uma matriz de correlações simples, escolhe-se a variāvel mais altamente correlacionada com a variável dependente. Em seguida selecionase, pelos coeficientes de correlação parcial, outra variável que apresente o mais alto coeficiente com a variável dependente para compor a equação juntamente com a primeira. A cada nova variāvel na regressão deve-se examinar o coeficiente de correlação multipla $\mathrm{R}^{2}$ e valor $F$, para se verificar a contribuição da variável adicionada na significância da equação.

A ànālise de regressao foi também utilizada 
para determinação das cores Munsell/densitométricas das amostras de solos, exigindo transformação dos dados em $\log x$. Para anālise de variāncia foi considerado o delineamento inteiramente casualizado, teste $F$, seguido quando necessārio, do teste de Duncan, para julgar a significāncia dos confrontos entre médias de tratamentos. 
4. RESULTADOS E DISCUSSAOO

\subsection{Comportamento espectral dos solos estudados}

Foram obtidos 9 espectros áticos de absorção, referentes às amostras dos solos estudados (Apēndice 5), em condições de laboratōrio, com utilização do espectrōmetro fotoacústico, descrito em 3.2.1.

os dados de reflectancia espectral com base nos espectros fotoacủsticos são apresentados nas Tabelas 8,9 e 10 .

Utilizando-se a média dos dados de reflectāncia espectral, para os trés tipos de solo estudados, foram construidos histogramas representativos das intensidades relativas de reflectāncia dessas amostras, bem como representações gräficas desses resultados, com a finalidade de melhor visualização do comportamento espectral desses solos. Figuras 6 e 7.

Pelo exame dos gräficos de intensidade de reflectāncia do espectro fotoacústico, representados pela 


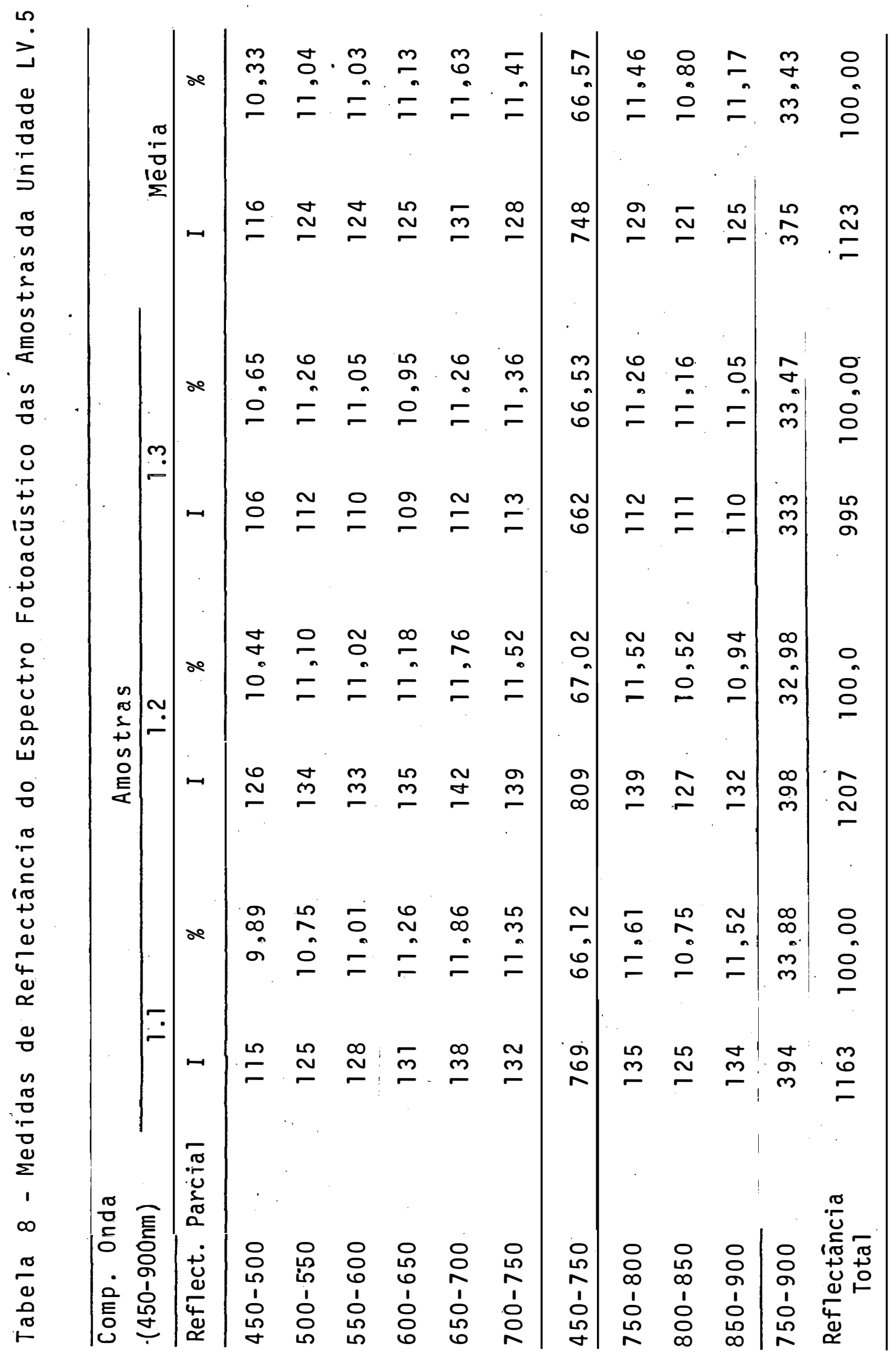




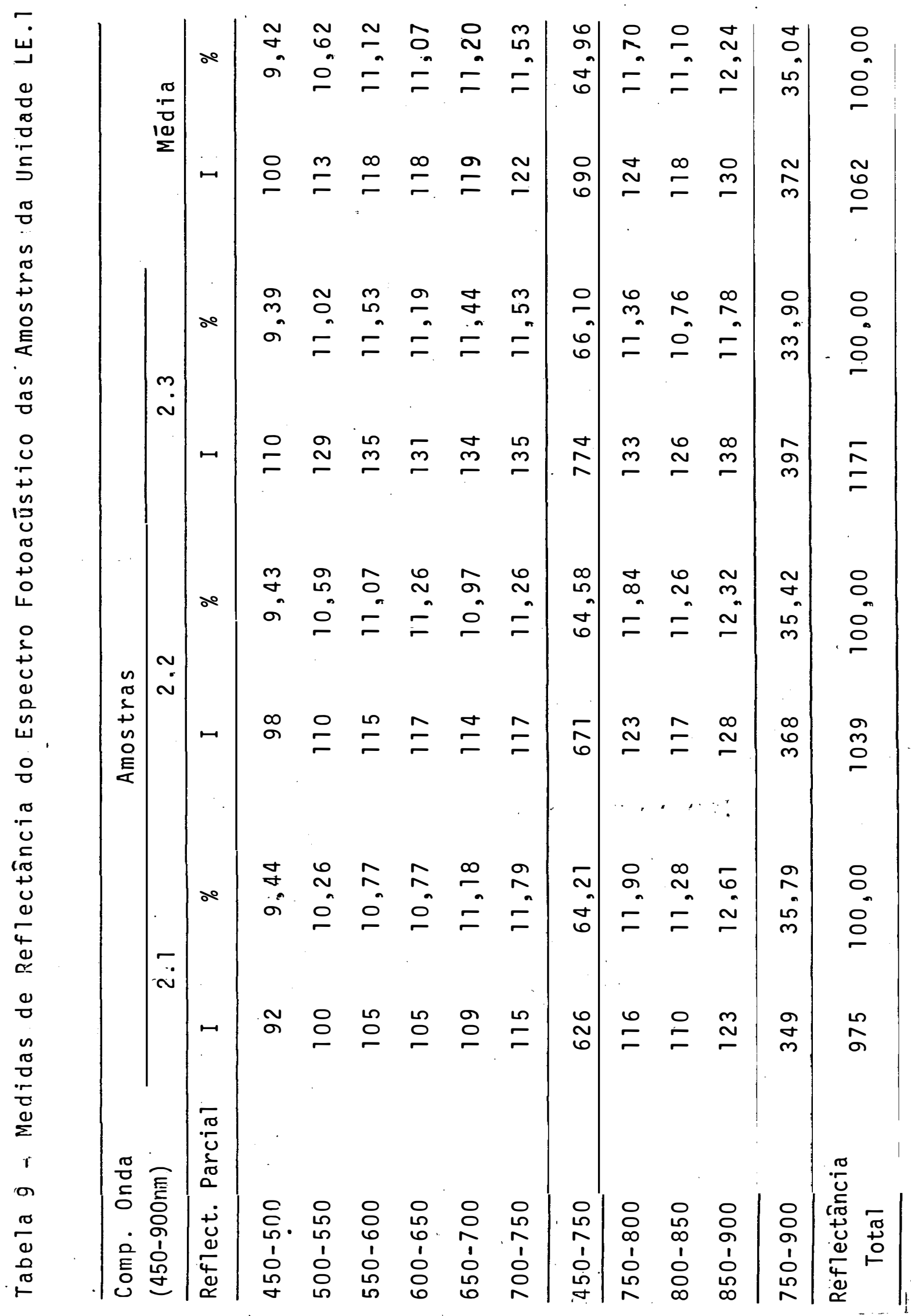




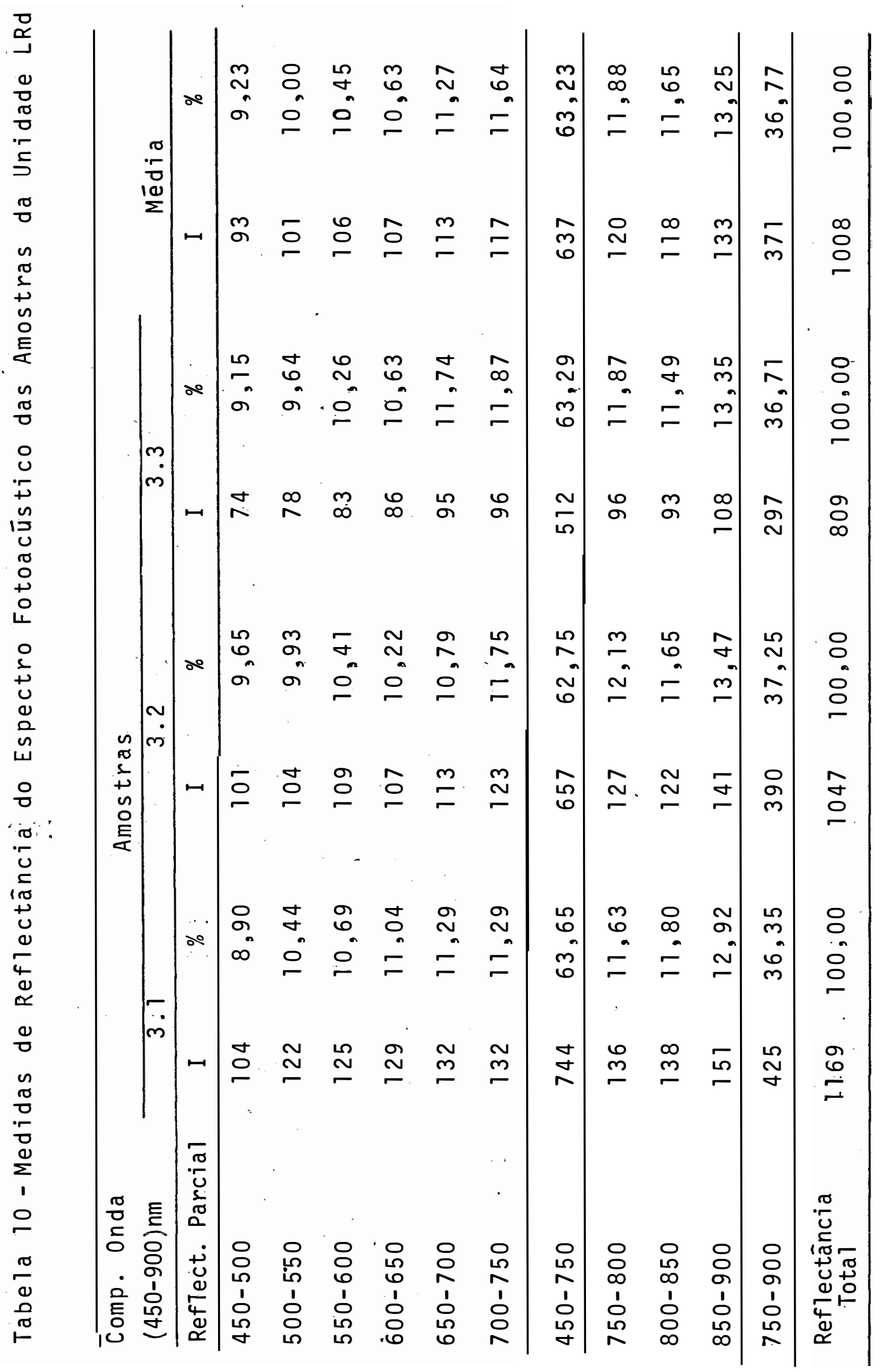




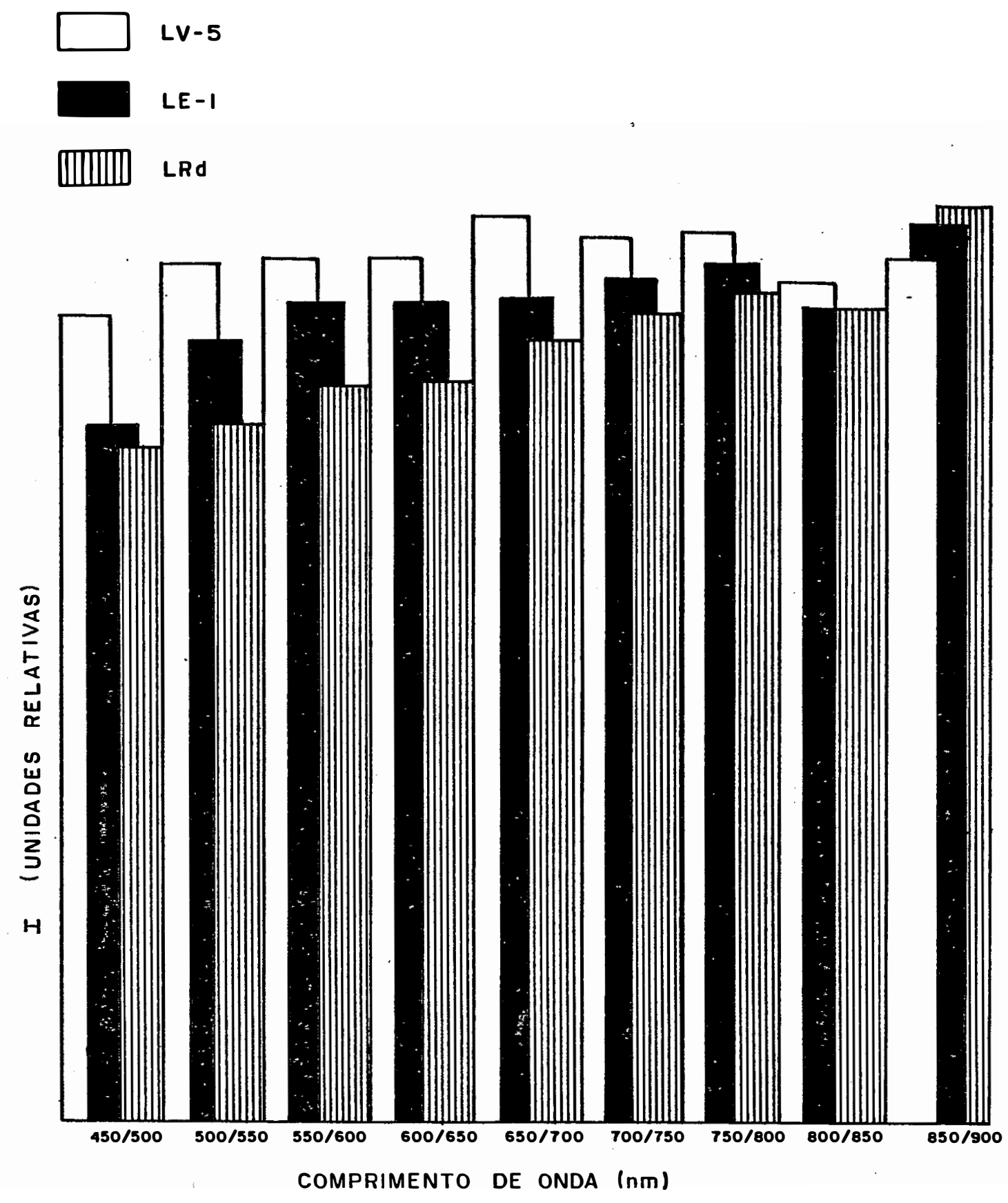

Fig. 7 - Histograma representativo do espectro fotoacústico de reflectāncia de valores médios, por faixa espec tral, para os 3 solos estudados. 


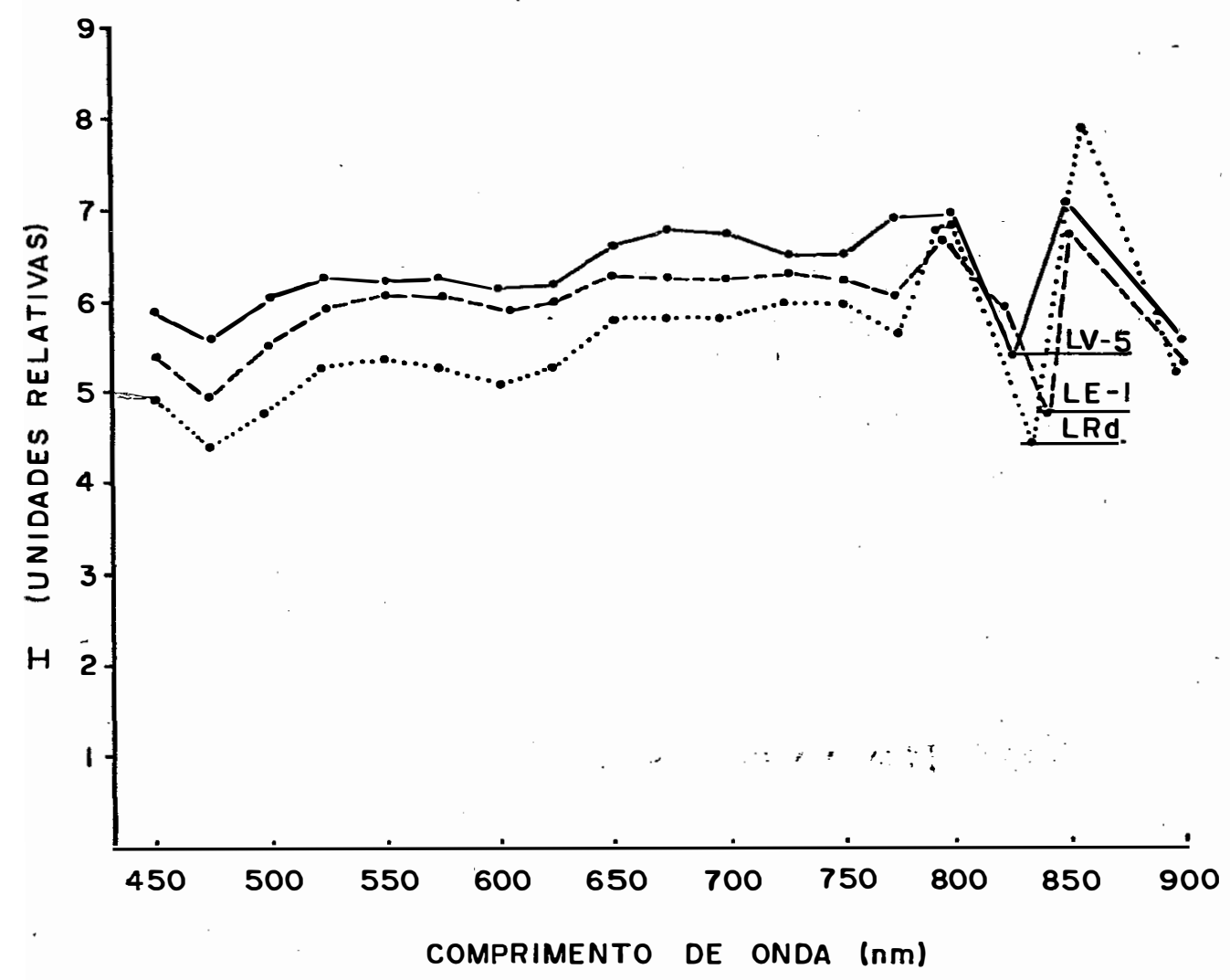

Fig. 8 - Representação grāfica do espectro fotoacūstico de reflectancia de valores médios, para os 3 solos estudados. 
Figura 7, pode-se verificar que, nas condições das amostras analisadas, a unidade LRd foi a que apresentou, em média, as menores intensidades de reflectāncia do espectro visível até 750-780 nanōmetros.

As amostras da unidade LE.I apresentaram um comportamento espectral semelhante às do LRd, na faixa de 450-780 nanómetros, no que se refere às formas das curvas, apresentando no entanto, maior amplitude de reflectäncia. As amostras da unidade LV.5, além de apresentarem maior amplitude de reflectância que as duas primeiras, apresentaram tambēm algumas diferenças na forma da curva, especialmente nas faixas 650-750 nm e 750-780 nm, como ilustra a Figura 7 .

$\mathrm{Na}$ faixa do infravermelho reflectivo, acima dos $780 \mathrm{~nm}$, pode-se notar que as amostras dos três solos estudados apresentaram um pico de absorção de energia por volta dos 830 nanōmetros e pico de reflectāncia por volta dos, 85,0 nm, com algumas diferenças quanto à intensidade do sinal fotoacústico. As amostras da unidade LV.5 continuaram a apresentar diferenças no formato da curva em relação aos dois outros solos. As amostras da unidade LRd apresentaram, nessa faixa, as maiores intensidades do sinal fotoacustico nos picos de absorção ou reflectância, mostrando diferenças de comportamento espectral relativamente às amostras das outras duas unidades. No histograma da Figura 6 pode-se notar a diferença de comportamento espectral dos Latossolos Roxos, unidade LRd, que passaram da menor intensidade de reflectāncia 
no visível, até 750-800 nm, em relação aos outros dois solos para maior intensidade no infravermelho, 850-900 nm. Comparando com os resultados obtidos por outros pesquisadores, pode-se fazer as seguintes considerações: Em solos de textura fina, com altos teores de $\mathrm{Fe}_{2} \mathrm{O}_{3}$ e relativamente baixos teores de matéria orgānica, semelhantes aos solos estudados neste trabalho (Typic Haplortox), alguns pesquisadores como STONER e BAUMGARDNER (1961), ADRIEN et alii (1982) e STONER et alii (1980) apontaram curva característica com inflexão apôs os $750 \mathrm{~nm}$ e faixa de absorção de ferro entre 800-900 nm à semelhança do que foi constatado no presente trabalho.

Outra observação refere-se à maior intensidade do sinal fotoacūstico dos espectros áticos de absorção obtidos em solos mais escuros e mais ricos em ferro, concordando com MOREIRA-NORDEMANN et alii (1983).

Esses espectros diferem apenas quanto à faixa de absorção de ferro, relatada por esses autores na regiãodo laranja-vermelho, enquanto que no presente trabalho essa faixa encontra-se no infravermelho reflectivo.

observa-se que o pico de absorção por volta de $820 \mathrm{~nm}$ é tanto mais pronunciado quanto maiores são os teores de $\mathrm{Fe}_{2} \mathrm{O}_{3}$; e solos com maiores teores de óxidos de ferro apresentaram menor reflectāncia total, estando esta observação de acordo com o relato de MATHEWS et alii (1973).

As amplitudes de reflectāncia diretamente proporcionais ao tamanho das partículas, em solos argilosos, 
foram também observados por STONER et alii (1980), à semeIhança dos resultados da presente pesquisa.

Este comportamento é possivelmente explicado, segundo considerações de STONER et alii (1980), pela, capacidade desses solos reterem teores de umidade tanto maiores, quanto mais argilosos forem, sob condições semelhantes, no caso TFSA, e estarem associados com teores crescentes de matéria orgānica, o que é vālido na presente pesquisa.

A anālise dos dados quantitativos de medidas de reflectāncia do espectro fotoacústico, Tabelas 8,9 e: 10 , comprovam as diferenças mēdias discutidas para os gräficos e histogramas. No entanto, os dados apresentados em tabelas representam intervalos espectrais de $50 \mathrm{~nm}$, o que mascara as pequenas diferenças de comportamento espectral das amostras. Alēm disso, verifica=se grande variabilidade dos dados, principalmente quando se consideram as variações de amplitude de reflectância, que são influenciadas por fatores não controlados, como por exemplo o teor de umidade, não podendo os mesmos serem discriminados quando agrupados segundo os tipos de solos. O teor de umidade, no caso, não afeta a forma da curva e sim sua amplitude, como observaram BOWERS e HANKS (1965), MONTGOMERY (1974) e COSTA (1979).

os dados de relações entre valores de reflectância em vārias regiões do espectro são mais recomendáveis para essas comparações, refletindo melhor o comportamento espectral relativo dos solos, procedimento adotado por diversos 
autores como PIECH e WALKER (1974), e tambēm :FORMAGGIO (1983) e KOFFLER (1982), que utilizaram razões espectrais em suas pesquisas.

Nas Tabelas 11 e 12 pode-se visualizar os dados de reilações entre reflectância do espectro fotoacūstico das amostras de solos, entre duas, regiões: visivel (450-750 nm) /infrayermelho (750-900 nm).

Nas Tabelas $13,14,15 ; 16,17$ e 18 são apresentados os dados de transmitância relativa por região espectral em imagens de transparēncias coloridas normais e infravermelhas, para cada unidade de solo; e na Tabela 19 são apresentados os valores de réflectância densitomētrica relativa das amostras de solo. Na Tabela 20 são apresentados os valores das relaçōes entre medidas de transmitância relativa em transparēncias infrayermelhas coloridas.

As cores Munsell/densitométricas obtidas a partir de dados de transmitáncia relativa em imagens coloridas normais são apresentádas na Tabela 21; e as cores Munse1:1/ /densitomētricas obtidas a partir de dados de reflectância densitomētrica relativa para amostras de solo:são apresentadas na Tabela 22 .

A anālise de variância dos dados das Tabelas 11 , 12 e 20 aponta diferenças significativas entre solos pe10 teste $F$, para relação entre valores do espectro fotoacūstico, especialmente para os intervalos 450-500/800-900 nm, e também para imagens de aerofotografias infravermelhas. Nestas $\bar{u} 1$ timas ocorrem pequenas diferenças dessas relações entre 

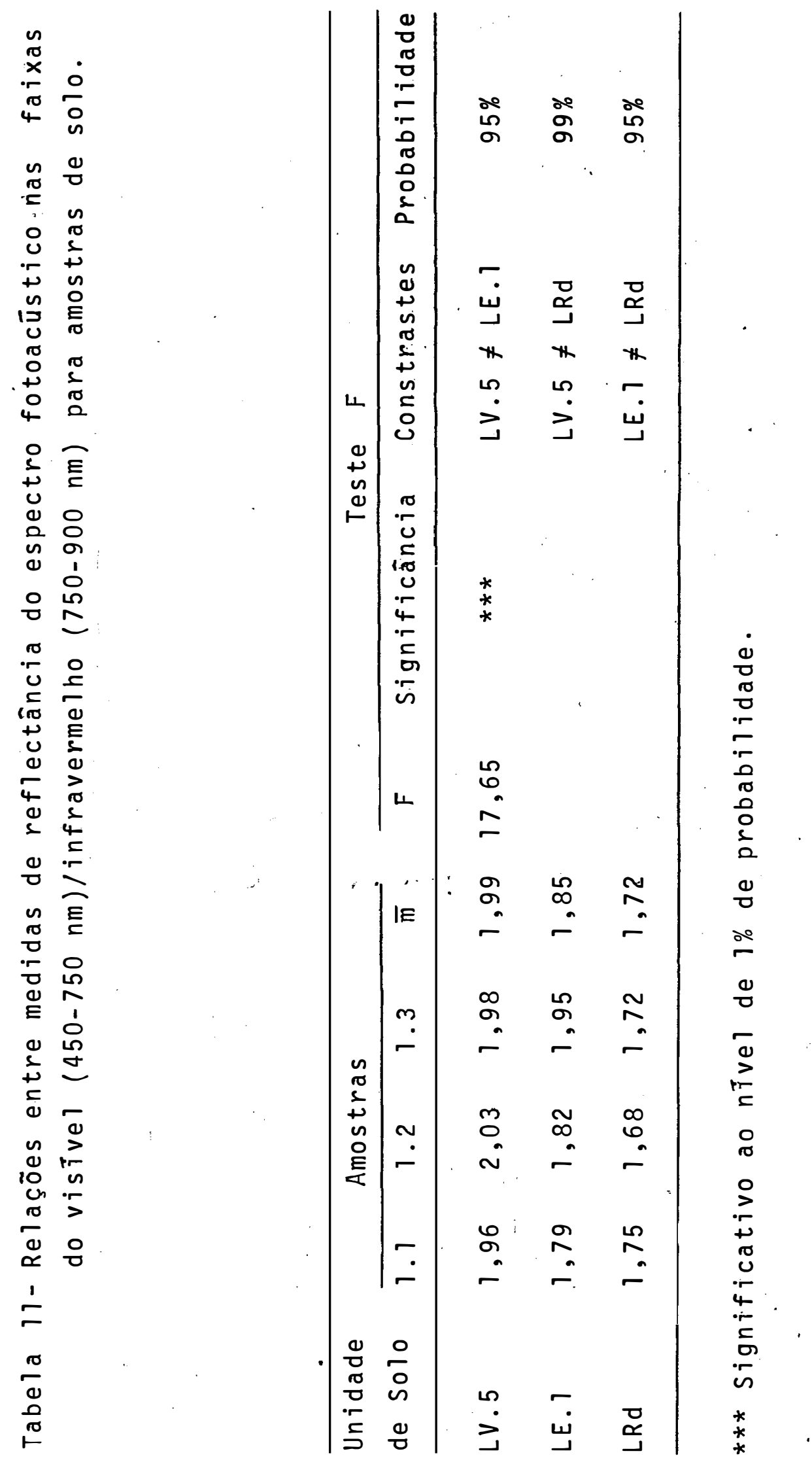


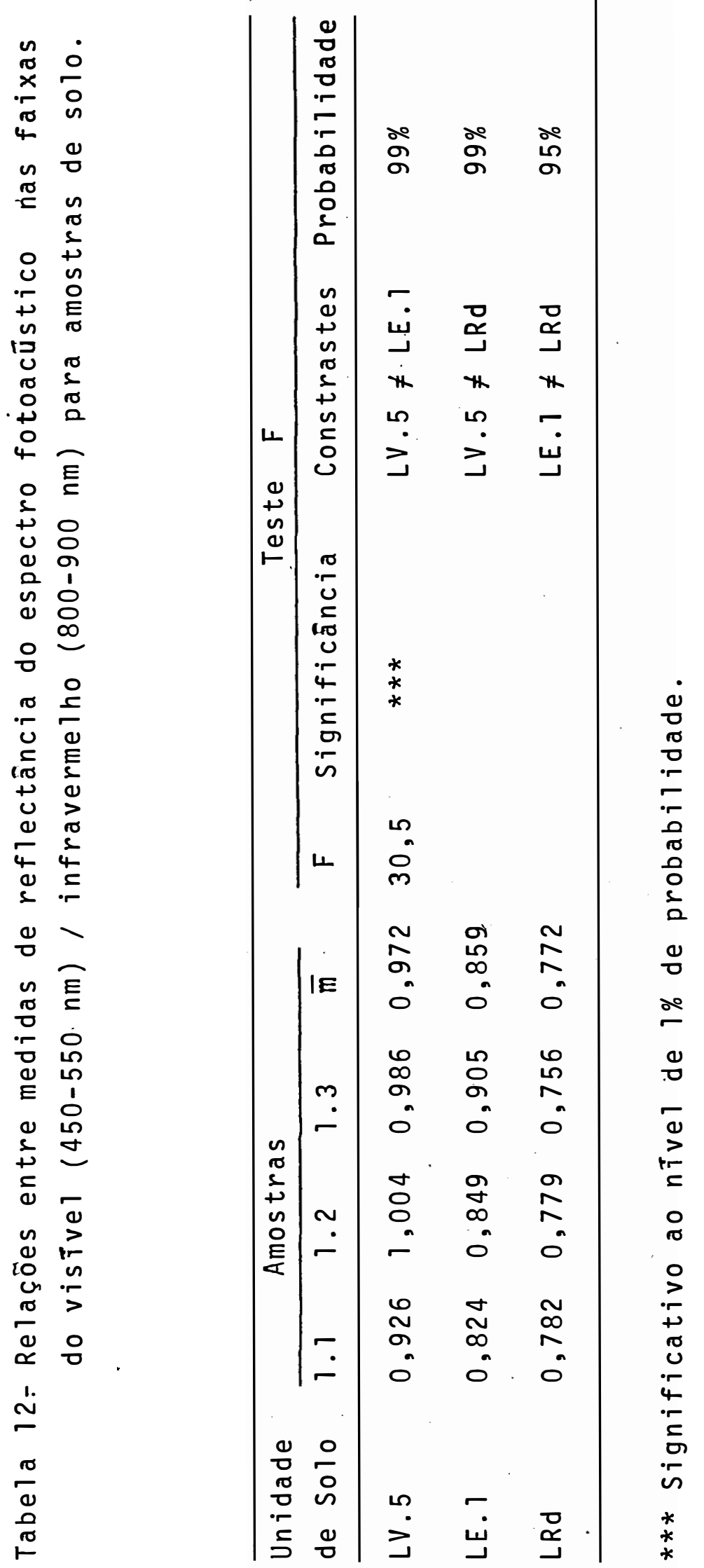




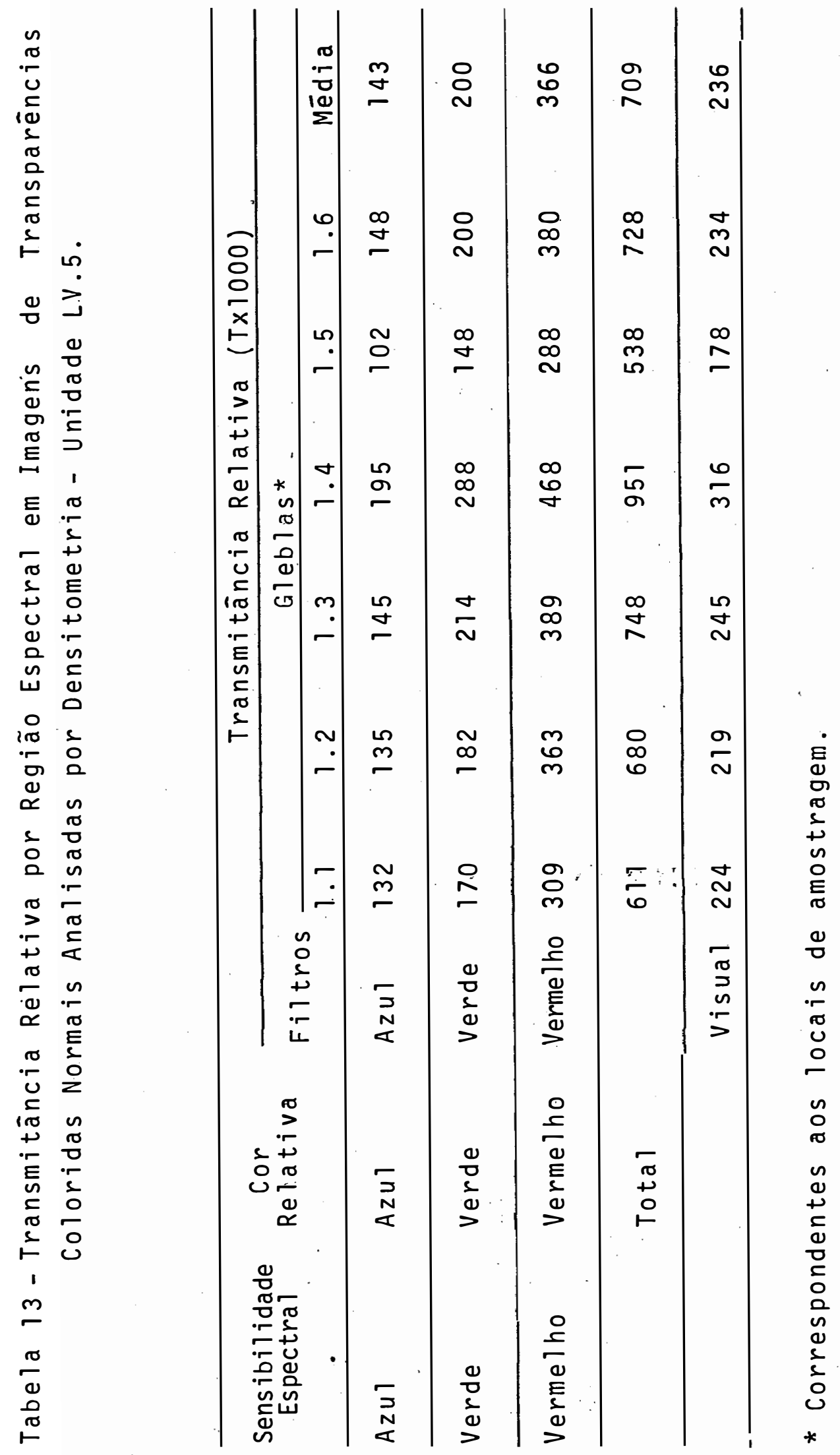




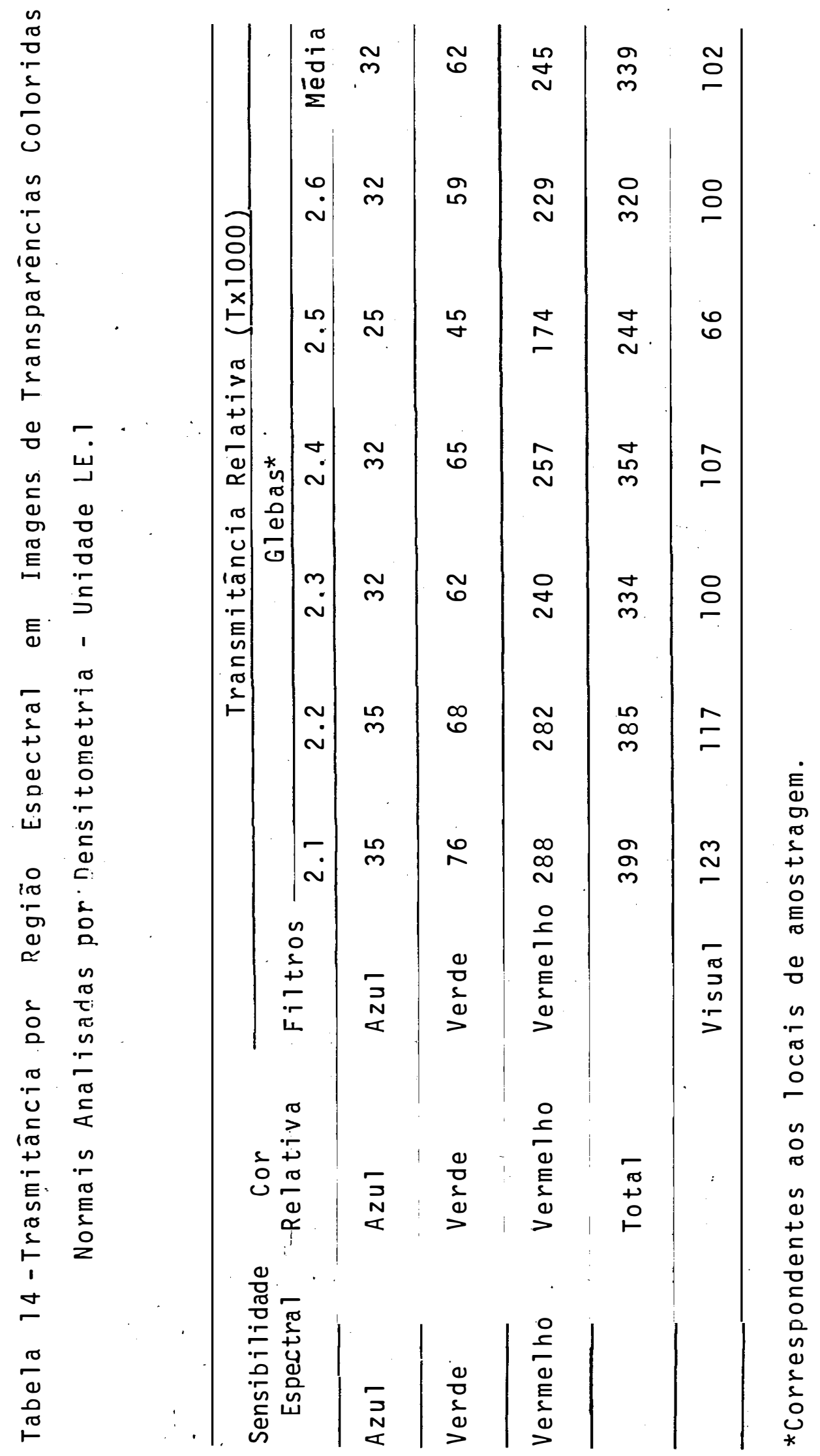




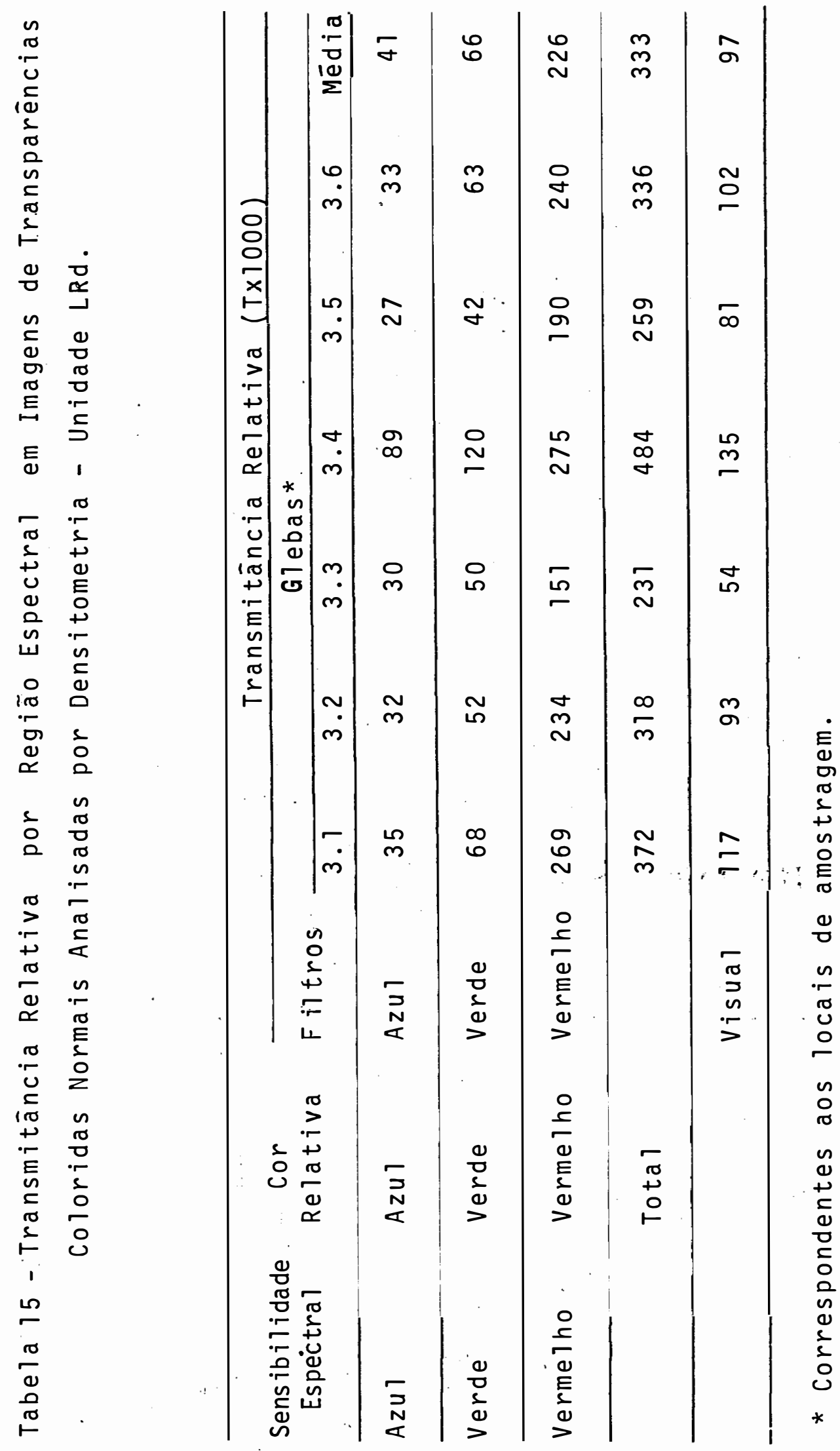




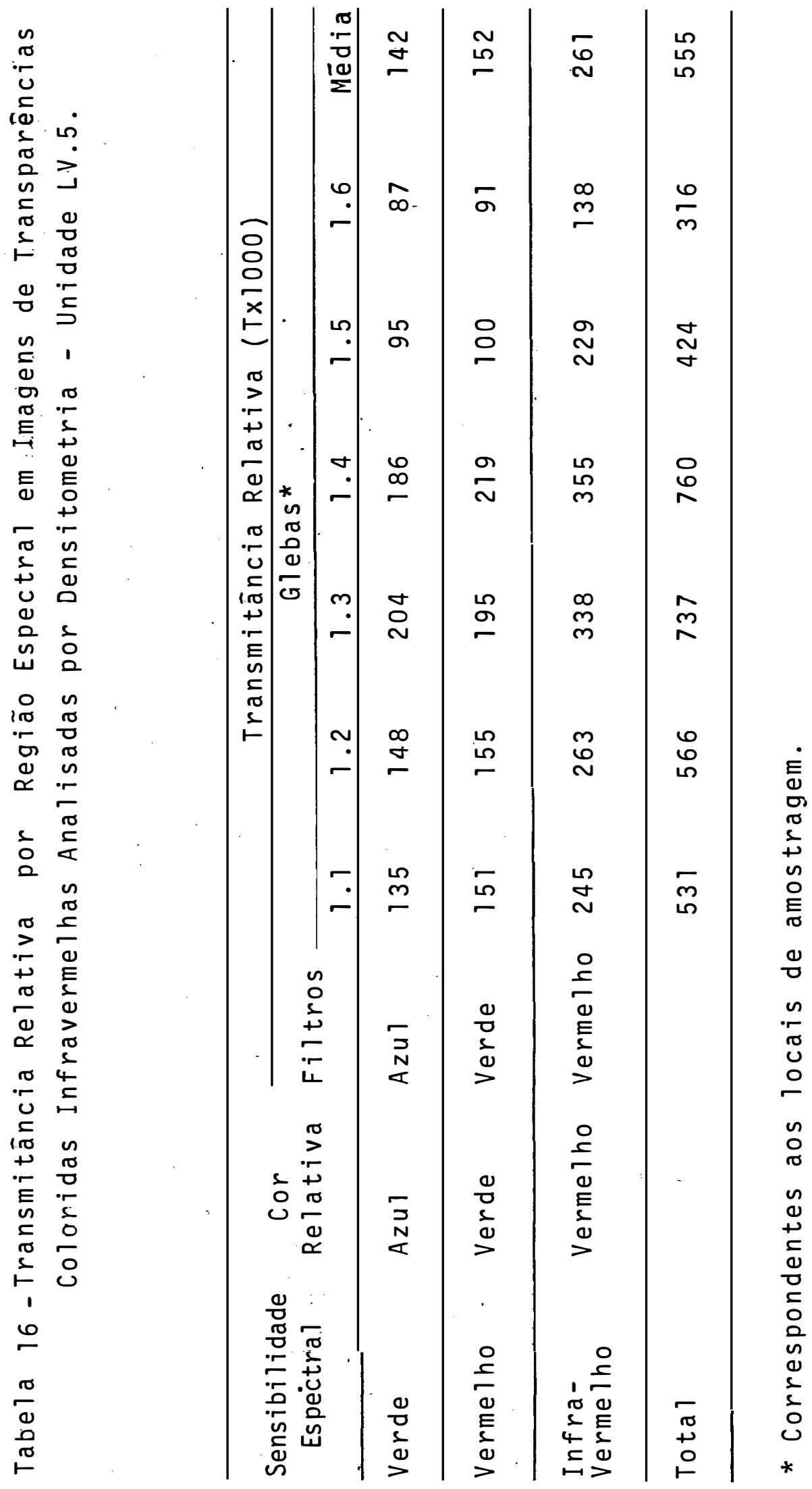




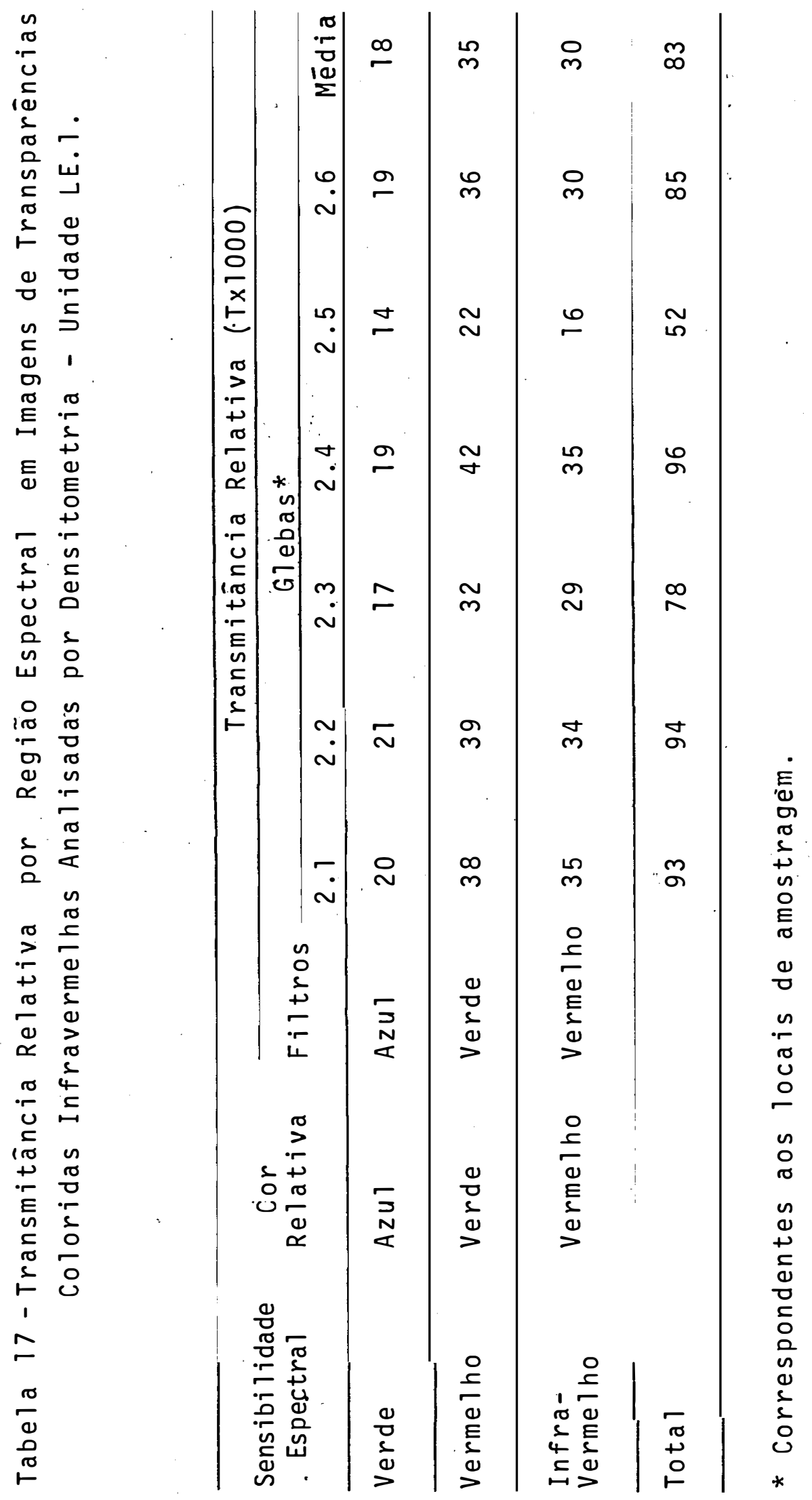




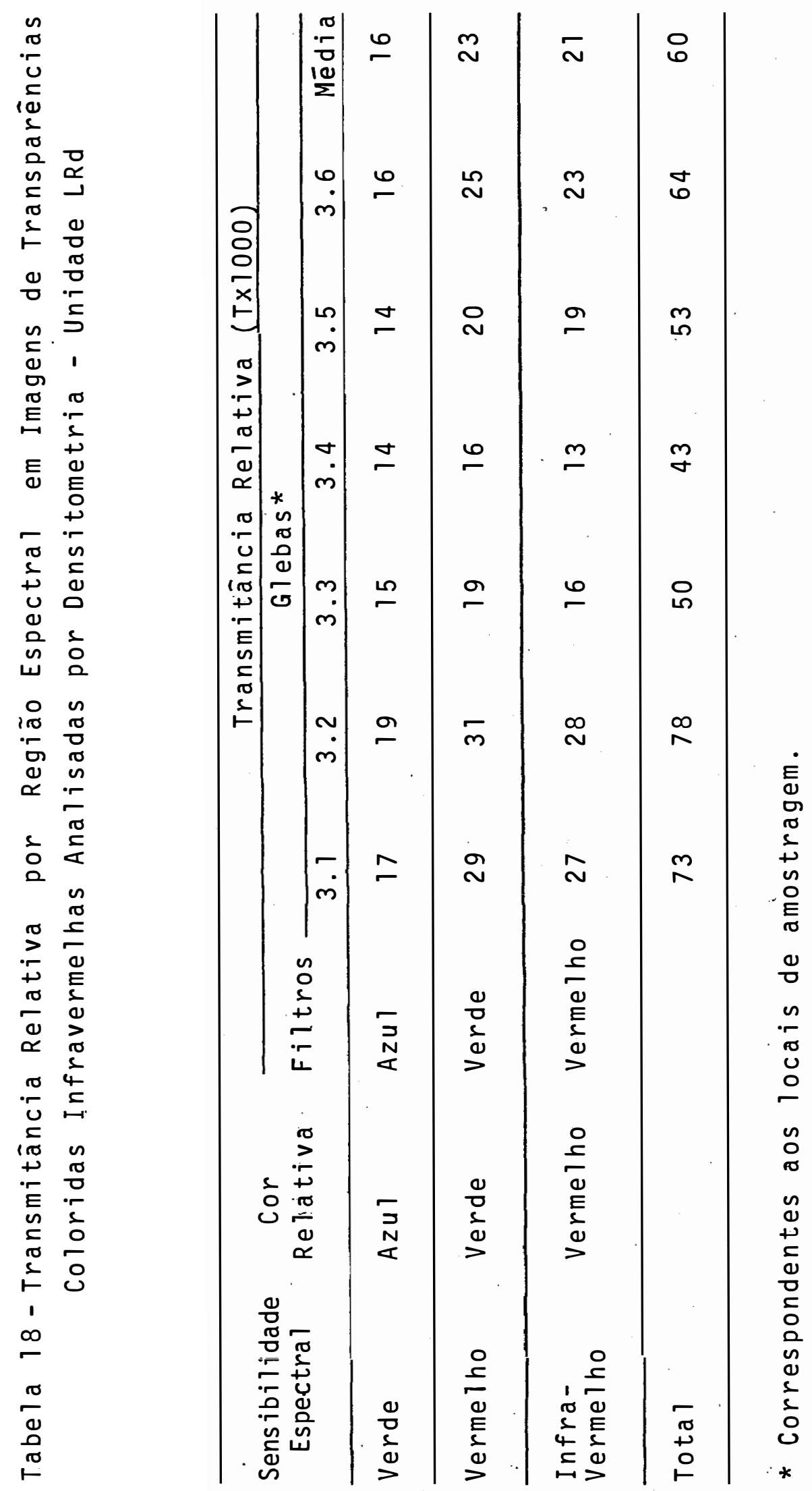




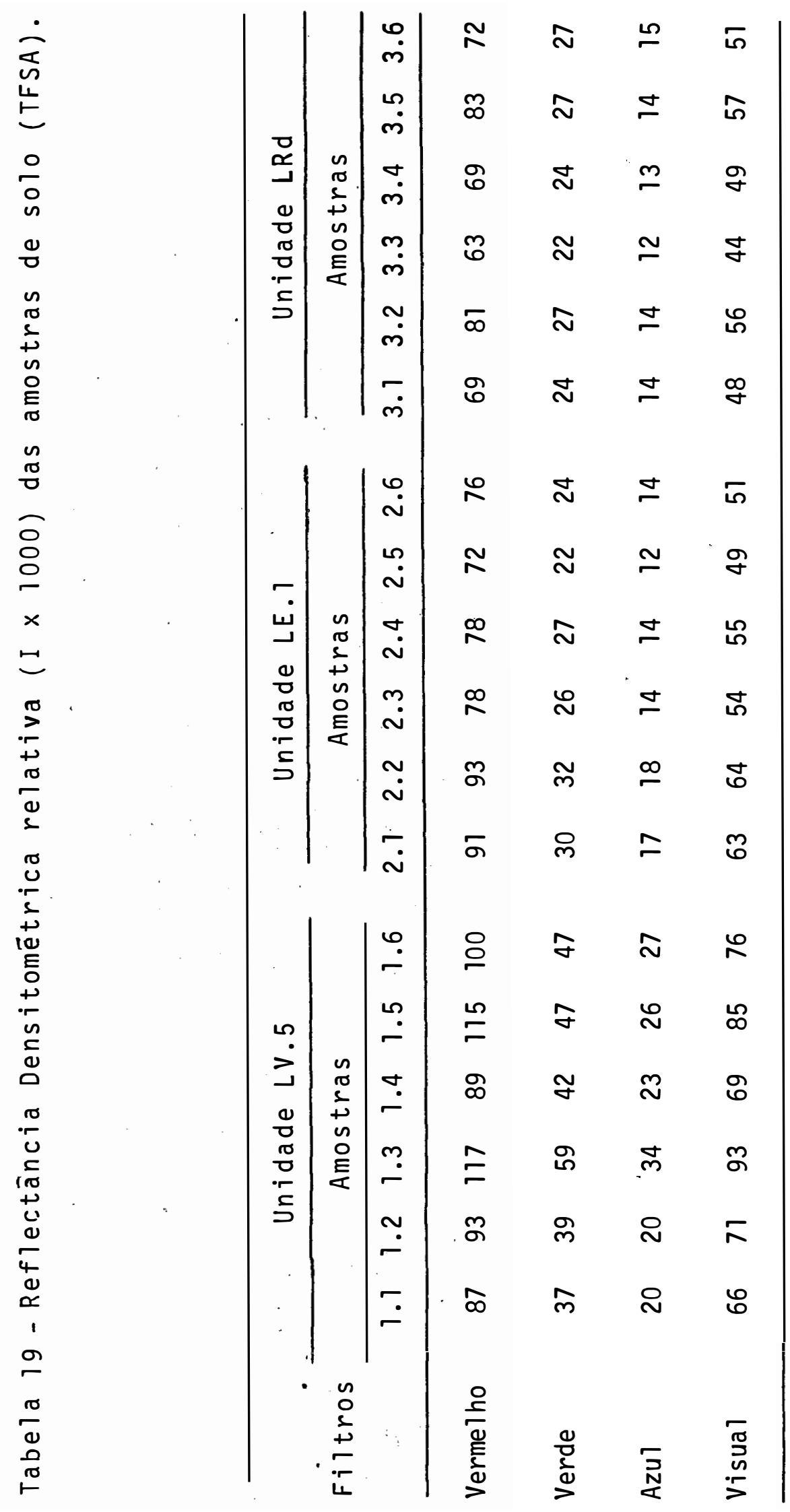




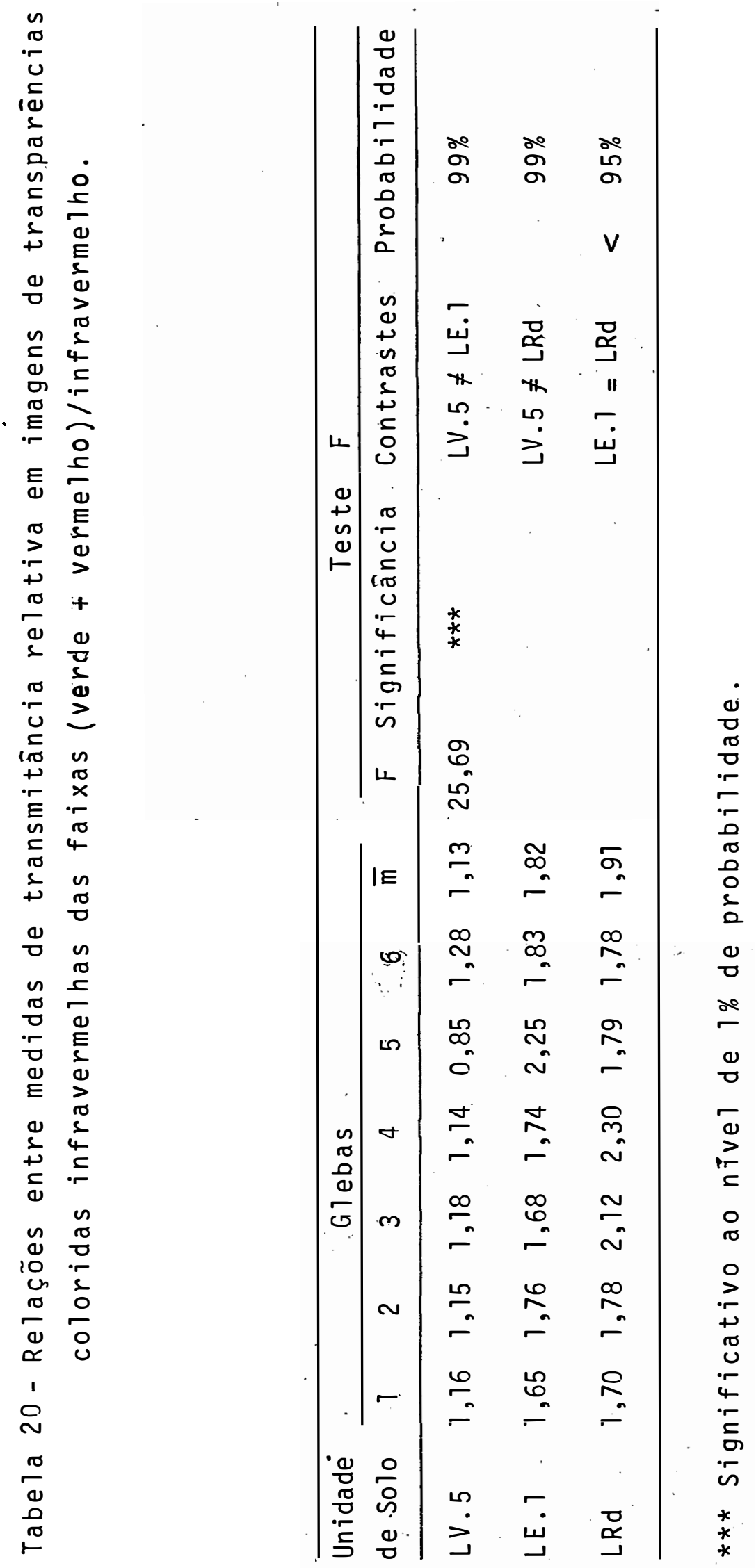


Tabela 21 - Notaçāo Munsell/densitomētrica das imagens de transparēncias coloridas normais.

\begin{tabular}{|c|c|c|c|}
\hline \multirow[b]{2}{*}{ Solo } & \multirow[b]{2}{*}{ Gleba* } & \multicolumn{2}{|c|}{ Cor } \\
\hline & & Matiz & Valor/Croma \\
\hline \multirow{6}{*}{ LV. 5} & 1.1 & $4,4 Y R$ & $4,6 / 2,7$ \\
\hline & 1.2 & $4,1 Y R$ & $4,6 / 3,2$ \\
\hline & 1.3 & 5,9 YR & $4,8 / 3,2$ \\
\hline & 1.4 & $7,1 Y R$ & $5,6 / 2,8$ \\
\hline & 1.5 & $5,2 \quad \mathrm{YR}$ & $4,2 / 3,4$ \\
\hline & 1.6 & $4,6 Y R$ & $4,7 / 3,0$ \\
\hline \multirow{6}{*}{ LE. 1} & 2.1 & $2,9 \quad \mathrm{YR}$ & $3,6 / 8,0$ \\
\hline & 2.2 & $1,9 Y R$ & $3,6 / 8,0$ \\
\hline & 2.3 & $2,3 \quad \mathrm{YR}$ & $3,4 / 8,0$ \\
\hline & 2.4 & $2,3 \quad \mathrm{YR}$ & $3,5 / 8,0$ \\
\hline & 2.5 & $1,9 \mathrm{YR}$ & $3,1 / 8,0$ \\
\hline & 2.6 & $2,0 Y R$ & $3,4 / 8,0$ \\
\hline \multirow{6}{*}{ LRd } & 3.1 & $3,1 Y R$ & $3,6 / 8,0$ \\
\hline & 3.2 & 0,4 YR & $3,3 / 8,0$ \\
\hline & 3.3 & $2,9 Y R$ & $2,9 / 6,2$ \\
\hline & 3.4 & $3,0 \mathrm{YR}$ & $3,8 / 3,7$ \\
\hline & 3.5 & $0,1 Y \mathrm{YR}$ & $3,2 / 8,0$ \\
\hline & 3.6 & $2,3 Y \mathrm{YR}$ & $3,4 / 8,0$ \\
\hline
\end{tabular}

* Correspondentes aos locais de amostragem. 
Tabela 22 - Notação Munsell/densitométrica das amostras de solos (TFSA).

\begin{tabular}{|c|c|c|c|}
\hline \multirow[b]{2}{*}{ Solo. } & \multirow[b]{2}{*}{ Amostra } & \multicolumn{2}{|c|}{ Cor } \\
\hline & & Matiz & Valor/Croma \\
\hline \multirow{6}{*}{ LV. 5} & 1.1 & 5,3 YR & $3,1 / 5,3$ \\
\hline & 1.2 & $5,4 Y R$ & $3,1 / 5,7$ \\
\hline & 1.3 & $6,3 \quad \mathrm{YR}$ & $3,3 / 4,2$ \\
\hline & 1.4 & $6,1 Y R$ & $3,1 / 4,7$ \\
\hline & 1.5 & $4,9 \quad \mathrm{YR}$ & $3,2 / 5,4$ \\
\hline & 1.6 & $5,7 \quad \mathrm{YR}$ & $3,2 / 4,5$ \\
\hline \multirow{6}{*}{ LE. 1} & 2.1 & 3,3 YR & $3,0 / 6,6$ \\
\hline & 2.2 & $3,6 Y R$ & $3,0 / 6,4$ \\
\hline & 2.3 & $3,6 \quad Y R$ & $2,9 / 6,9$ \\
\hline & 2.4 & $4,1 Y R$ & $2,9 / 6,9$ \\
\hline & 2.5 & $3,0 \quad Y R$ & $2,9 / 7,5$ \\
\hline & 2.6 & $2,8 Y R$ & $2,9 / 6,7$ \\
\hline \multirow{6}{*}{ LRd } & 3.1 & $3,4 \quad \mathrm{YR}$ & $2,9 / 6,1$ \\
\hline & 3.2 & $3,8 Y R$ & $2,9 / 7,2$ \\
\hline & 3.3 & $3,8 \quad \mathrm{YR}$ & $2,8 / 6,5$ \\
\hline & 3.4 & $3,8 Y R$ & $2,9 / 6,6$ \\
\hline & 3.5 & $3,6 \quad Y R$ & $2,9 / 7,4$ \\
\hline & 3.6 & 4,2 YR & $2,9 / 5,9$ \\
\hline
\end{tabular}


os solos LE.l e LRd, cujos contrastes analisados pelo teste de Duncan, complementar do Teste $F$, não apresentaram diferenças significativas atẻ o nīvel de $5 \%$ de probabilidade.

\subsection{Relações entre cores dos solos e suas respectivas i- magens aerofotogrāficas.}

A comparação das cores Munsell/densitométricas obtidas para amostras de solos e em imagens de transparéncias coloridas normais, revela altos coeficientes de correlação simples, significativos ao nível de $1 \%$ de probabilidade para - matiz, valor e cromá Munsell/densitométricos, como se pode obsevar na Tabela 23.

Esses resultados confirmam aqueles encontrados em pesquisa anterior (DONZELI, 1979), segundo metodologia proposta por RIB (1968) para determinação das cores Munsell/densitomētricas, concordando tambēm com DOMINGUES (1960), que encontrou altas correlações entre as cores dos solos e cores registradas em fotos aéreas. No entanto, pelo confronto das Tabelas 21 e 22 pode-se notar que não houve grande precisão na fidelidade de reprodução das cores dos solos pelas fotografias aéreas coloridas. Em geral, as imagens de transparēncias aerofotográficas coloridas apresentaram matizes ligeiramente mais vermelhos em todas as amostras, representados por valores em média 1,14 YR mais baixos do que as amostras de solos. Pode-se também notar valores mais baixos para a relação valor/croma dos solos mais claros, como os pertencentes à 
Tabela :23-Coeficiente de correlação simples entre cores Munsell/densitométricas das amostras de solos e respectivas imagens fotográficas.

\begin{tabular}{lcc}
\hline Cor & $\mathrm{R}$ & $\mathrm{R}^{2}$ \\
\hline Matiz & $0,82 * *$ & 0,67 \\
Valor & $0,83 * *$ & 0,69 \\
Croma & $0,80 * *$ & 0,64 \\
Valor/Croma & $0,85 * *$ & 0,72 \\
\hline
\end{tabular}

** Significativo ao nível de $1 \%$ de probabilidade. 
unidade. LV.5, enquanto que para a relação valor/croma dos solos mais escuros, houve boa correspondencia, embora essa relação tenha sido obtida com "valor e croma" mais baixos nas amostras de solos. PARRY et alii (1969) relatam resultados semelhantes, não encontrándo sempre a exata correspondēncia entre as cores dos solos e cores em cópias fotogrāficas.

A diferença entre as cores Munsell/densitométricas das amostras de solos e respectivas imagens fotogrāficas, tanto pode ser devida aos fatores inerentes aos filmes fotogräficos (exposição, processamento) ou que interferem na obtenção das imagens, como os citados por LUEDER (1959), RAY (1963), RICCI e PETRI (1965), STEINER e HAEFNER (1965), ESTES e SIMONETT (1975), como tambēm ao processo de obtenção de dados densitométricos. Neste caso, pode-se citar especialmente, o uso de laminulas de vidro sobre as amostras, ... metodologia desaconselhada:por MONTGOMERY et alii (1976) e outros pesquisadores citados por estes, que de maneira semelhante, encontraram pequenas diferenças constantes, entre leituras espectrométricas obtidas diretamente, ou através de placas de vidro colocadas sobre as amostras.

Para os resultados apresentados, as cores Munsell/densitométricas das amostras de solos foram mais semelhantes às cores centrais das unidades de solo descritas por OLIVEIRA et alii (1982), que na pesquisa anterior de DONZELI $(1979)$. 
4.3. Relações entre dados de reflectāncia do espectro fotoacūstico dos solos, caracterīsticas físicas e quĩmicas e registros de tonalidade em aerofotografias

No Apêndice 1 podem ser observados os dados de. anālises físicas e quīmicas das amostras dos solos estudadas, com exceção da cor Munsell/densitomëtrica que se encontra na Tabe 1 a. 22 .

As relações quantitativas entre a intensidade e composição espectral da radiaçăo refletida pelas amostras de solos e suas características físico-químicas, expressa pelos parämetros constantes do Apêndice 1 e Tabela 22, foram avaliadas atravēs de equações de regressão entre as suas variāveis representativas.

A reflectāncia espectral em intervalos de $50 \mathrm{~nm}$, de 450 atē $900 \mathrm{~nm}$, contida nas Tabelas 8, 9 e 10, foi correlacionada a seis variāveis independentes, nūmero máximo limitado pelo nūmero de amostras analisadas, estando os coeficientes de correlação linear simples e parcial apresentados na Tabela 24 .

Como se pode observar, a significāncia dos coeficientes apresentados nessa tabela é relativamente baixa; desde que são significativos ao nīvel de $5 \%$ de probabilidade os coeficientes superiores a 0,66 .

Enquanto os coeficientes de correlação simples expressam as relações entre apenas duas variāveis numa matriz 


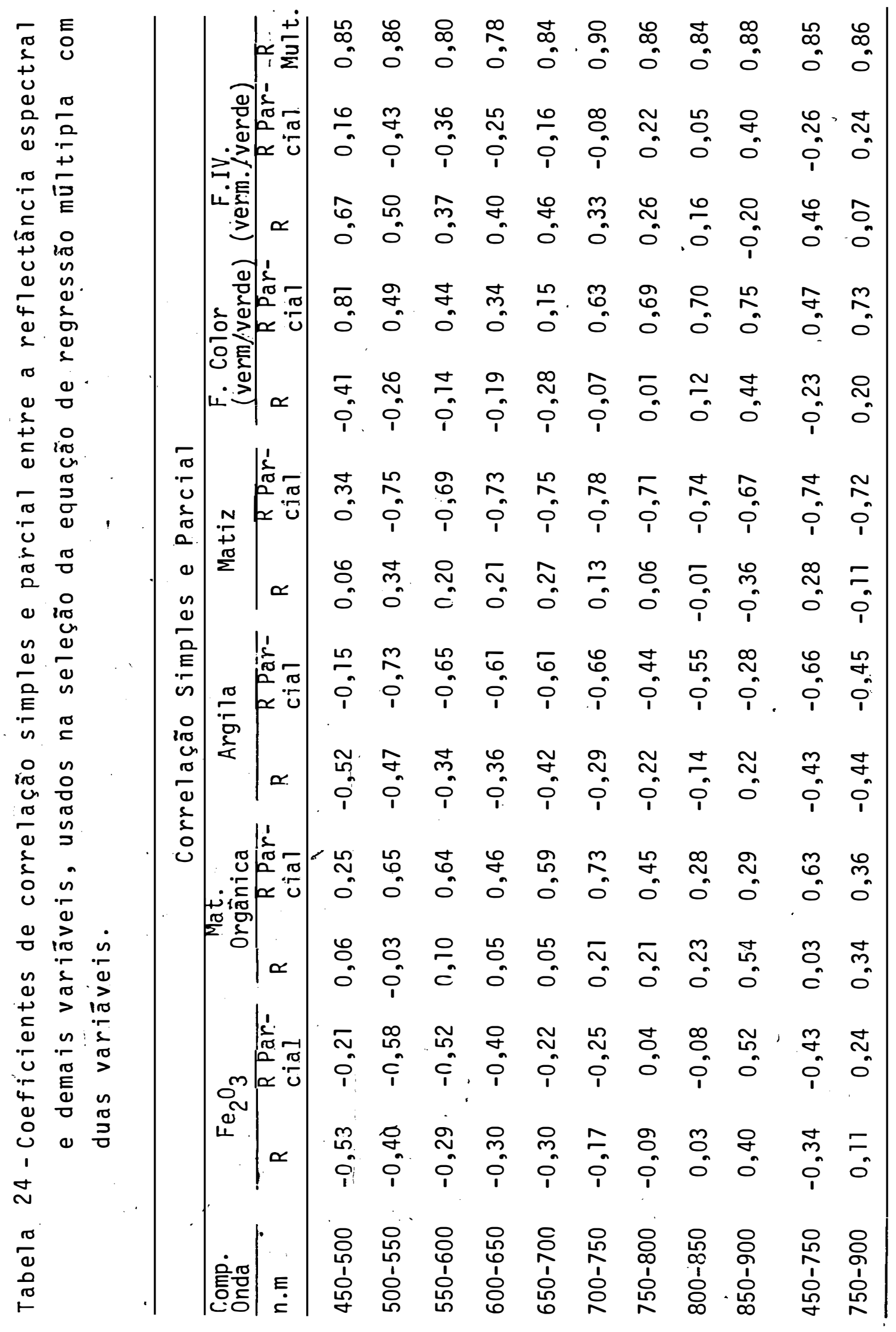


de correlações, os coeficientes de correlação parcial dão idêia da influência das outras variāveis no modelo.

A baixa significāncia da relação entre a reflectáncia do espectro fotoacústico e as variāveis estudadas são discutidas a seguir.

0 pequeno nümero de amostras analisadas. (nove amostras) limita, "a priori", a possibilidade de significāncia de baixos coeficientes de correlação.

A variabilidade dos valores de reflectāncia, devida apenas à amplitude das curvas que, por sua vez, pode ser resultante do efeito de variāveis naõ consideradas nessa pesquisa, $\bar{e}$ possivelmente a principal causa. Essa afirmativa pode ser comprovada pelo significativo aumento nos coeficientes de correlação simples com o uso de razões de reflectáncia entre faixas largas ou estreitas de regiões do visĩvel e infravermelho, apresentadas na Tabela 25.

os intervalos de $50 \mathrm{~nm}$, computados por integração das āreas sob as curvas de reflectāncia, podem ser demasiadamente largos, minimizando os efeitos diferenciais em estreitas faixas ou picos de absorção ou reflectāncia, afetando assim os resultados.

As duas variáveis que entraram nas regressões múltiplas apresentadas na Tabela 26 foram escolnidas com base nos coeficientes da Tabela 24 conforme a proposição de DRAPER e SMITH (1966) relatada em 3.8. 
A primeira variāvel das regressões, representada pela porcentagem de argila, foi a que apresentou o mais alto coeficiente de correlação simples, em todas as faixas de comprimento de onda. 0 matiz da cor apresentou o mais alto coeficiente de correlaçäo parcial, tambēm em todas as faixas do espectro, constituindo a segunda variāvel a integrar as equações de regressão mültipla. Apenas duas variāveis “ integram as equações pelo pequeno nūmero de amostras analisadas, devido ao valor limite do teste F para significância em função dos graus de liberdade residuais.

Os dados das Tabelas 24 e 25 , sendo analisados comparativamente, entre faixas do espectro, sem levar em consideração sua significāncia, são comentados a seguir.

Examinando-se os coeficientes de correlação simples entre a reflectāncia espectral e teores de óxidos de ferro livres, pode-se notar que existe uma relação inversa, na faixa do visivel, o que confere com observações feitas por vārios autores, como, Obukhov e orlov, citados por MONTGOMERY et alii (1976), MATHEWS et alii (1973). Coeficientes mais altos são notados nas faixas extremas do espectro estudado. $\mathrm{Na}$ faixa 450-500 nm notam-se os coeficientes mais elevados, que decrescem até $850 \mathrm{~nm}$, quando voltam a elevar-se bruscamente; apresentando nessa faixa do infravermelho, coeficientes positivos. A razão entre valores de reflectância para as regiões do visivel e do infravermelho, Tabela 25 , mostrou alta correlação significativa com os ōxidos de ferro, provando estar a faixa do infravermelho respondendo diferencialmente à do vi- 
Tabela 25 - Coeficiente de correlação linear simples entre razões de reflectāncia espectral e demais variáveis independentes.

\begin{tabular}{|c|c|c|c|c|}
\hline \multirow{2}{*}{$\begin{array}{l}\operatorname{Raz} \tilde{a} 0 \\
\text { de Reflect. } \\
(n \mathrm{n})\end{array}$} & \multicolumn{4}{|c|}{ Caracteristicas físico-quimicas dos solos } \\
\hline & $\mathrm{Fe}_{2} \mathrm{O}_{3}$ & Mat.Orgánica & Argila & Matiz \\
\hline$\frac{450-750}{750-900}$ & $-0,84 * *$ & $-0,48$ & $-0,78^{\star}$ & $0,73^{*}$ \\
\hline$\frac{450-550}{800-900}$ & $-.0,43$ & $-0,57$ & $-0,85 * \star$ & 0,82 ** \\
\hline
\end{tabular}

* Significativo a $5 \%$ de probabilidade;

** Significativo a $1 \%$ de probabilidade. 
Tabela 26 -Coeficientes de correlação entre valores de reflectância do espectro fotoacústico e par de variáveis selecionadas. Anālise de regressão multipla.

\begin{tabular}{|c|c|c|c|c|c|c|c|}
\hline $\begin{array}{l}\text { Faixa espec } \\
\text { tro }(\mathrm{nm})\end{array}$ & & Equação & o de Regre & ssão & $\mathrm{R}$ & $R^{2}$ & $F^{*}$ \\
\hline $450-500$ & $y=$ & 220,35 & $-\quad 1,17 x_{3}$ & $-3,22 x_{4}$ & 0,94 & 0,88 & 23,18 \\
\hline $500-550$ & $y=$ & $=1104,52-$ & $4 ; 31 \times_{3}$ & $-51,70 x_{4}$ & 0,80 & 0,64 & 5,31 \\
\hline $550-600$ & $y=$ & $=1076,57^{\prime}$ & $-4,05 x_{3}$ & $-50,58 x_{4}$ & 0,75 & 0,55 & 3,74 \\
\hline $600-650$ & $y=$ & $=1157,91$ & $4,38 x_{3}$ & $-54,87 x_{4}$ & 0,81 & 0,66 & 5,73 \\
\hline $650-700$ & $y=$ & $=1171,28$. & $-4,46 x_{3}$ & $-55,16 x_{4}$ & 0,86 . & 0,74 & 8,36 \\
\hline $700-750$ & $y=$ & $=1027,57$ & $-\quad 3,74 x_{3}$ & $-47,94 x_{4}$ & 0,81 & 0,65 & 5,62 \\
\hline $750-800$ & $y=$ & $=1064,10$ & $-\quad 3,84 x_{3}$ & $-50,0 x_{4}$ & 0,79 & 0,62 & 5,00 \\
\hline $800-850$ & $y=$ & 972,20 & $-\quad 3,43 x_{3}$ & $-45,61 x_{4}$ & 0,65 & 0,42 & 2,21 \\
\hline $850-900$ & $y=$ & $=996,70-$ & $-\quad 3,23 x_{3}$ & $-47,43 x_{4}$ & 0,77 & 0,59 & 4,30 \\
\hline $450-750$ & $y=$ & $=6369,10$ & $-24,28 x_{3}$ & $-297,50 x_{4}$ & 0,81 & 0,66 & 5,96 \\
\hline $750-900$ & $y=$ & $=3033,0$ & $-10,49 x_{3}$ & $-143,05 x_{4}$ & 0,78 & 0,61 & 4,80 \\
\hline
\end{tabular}

$x_{3}=\operatorname{argila}$

$x_{4}=$ matiz

* = valores de $F$ superiores a 5,13 significantes a $5 \%$ de probabilidade. 
sivel para teores crescentes de óxidos de ferro, concordando com relatos de MONTGOMERY et alii (1976), STONER et alii (1980). A matēria orgânica, de maneira geral, apresentou baixos coeficientes de correlação na faixa examinada (450- . $900 \mathrm{~nm})$, com exceção da faixa 850-900 nm do infravermelho onde o coeficiente foi mais alto. Entretanto, pesquisas de outros autores como BAUMGARDNER et alii (1970) revelaram altos coeficientes de correlação linear entre reflectāncia espectral e matēria orgānica, embora esses autores tivessem trábalhado com solos que apresentavam elevados teores de matēria orgānica.

As relações inversas entre razões espectrais e matéria orgānica, Tabela 25 conferem com citações de BOWERS e HANKS (1965), PAGE (1974), STONER e BAUMGARDNER (1981), AL-ABBAS at alii (1972), sendo que os coeficientes continuaram não significativos, embora mais elavados. 0 motivo para tal pode ser fundamentado na explicação de STONER e BAUMGARDNER (1981), que em solos com altos teores de $\mathrm{Fe}_{2} \mathrm{O}_{3}$, maiores que $4 \%$ em solos minerais, hā um mascaramento dos efeitos da matéria orgãnica na reflectāncia espectral.

Quanto ao teor de argila, os melhores coeficientes de correlação foram notados nas porções do espectro visivel, diminuindo no infravermelho. As faixas que apresentaram as melhores correlações foram 450-500 e 650-700 nm.

0 matiz correlacionou-se melhor com a reflectâncịa do espectro fotoacústico em sua porção mediana 
(550-700 nm - faixa do vermelho) e (850-900 nm - infravermelho), embora a faixa do visível como um todo tenha apresentado os mais altos coeficientes de correlação. Essas observações concordam com as de MYERS e ALLEN (1968), MONTGOMERY et alii (1976) e VALERIO FILHO et alii (1976), KRISTOFF et alii (1980), que citaram essas regiões do espectro como mais correlacionadas à cor do solo como um todo.

Nas correlações entre as razões espectrais nas faixas do visível e do infravermelho, a porcentagem de argila assim como o matiz, exibiram isoladamente coeficientes de correlação significativos com a reflectāncia espectral, sendo tambēm as duas variāveis selecionadas em conjunto nas equações de regressão, que se mostraram mais significativamente correlacionadas, em todo o espectro, à reflectāncia espectral, Tabela 26. As faixas 450-500 e 650-700 nm, novamente apresentaram os maiores coeficientes de corręlação, $R=0,94$ e 0,86 respectivamente para as equações de regressão mūitiplas.

As medidas de transmitancia relativa das imagens de fotografias coloridas infravermelhas mostraram-se mais altamente correlacionadas com os espectros fotoacusticos, que as das coloridas normais, sendo que ambas mostraram maiores correlações nas porçôes iniciais do espectro, ou seja, na faixa do visĩvel. 
4.4. Relações entre dados de reflectāncia densitométrica relativa dos solos, características físicas e quîmicas e. registros de tonalidade em aerofotografias.

As Tabelas 27 e 28 sintetizam essas relações atravēs de uma matríz de coeficientes de correlação simples e parcia 1.

- A reflectāncia densitométrica relativa das amostras de solo (Tabela 19), avaliada através dos filtros azul, verde e vermelho, representam esses dados em três regiões do espectro visĩvel.

A cor do solo, através de seus componentes matiz, valor e croma, sendo função dos dados densitométricos, se equivalem a estas medidas, guardando com elas altas correlaçoes.

Os dados de reflectāncia densitométrica, tendo sido obtidos com número maior de amostras, têm limițes de significância menores e tornam possível relacionar um maior nūmero de variảveis, como se observa nas Tabelas 27 e 28.

Aplicando-se a estes dados o mesmo raciocinio desenvolvido para as relações com a reflectāncia do espectro fotoacūstico, verifica-se que os componentes da cor, valor e matiz - seriam as variáveis escolhidas para integrarem equações de regressão mültipla por exibirem, respectivamente, os maiores coeficientes de correlaçōes simples e parcial, nos três filtros. Desprezando-se essas variāveis por serem origi- 


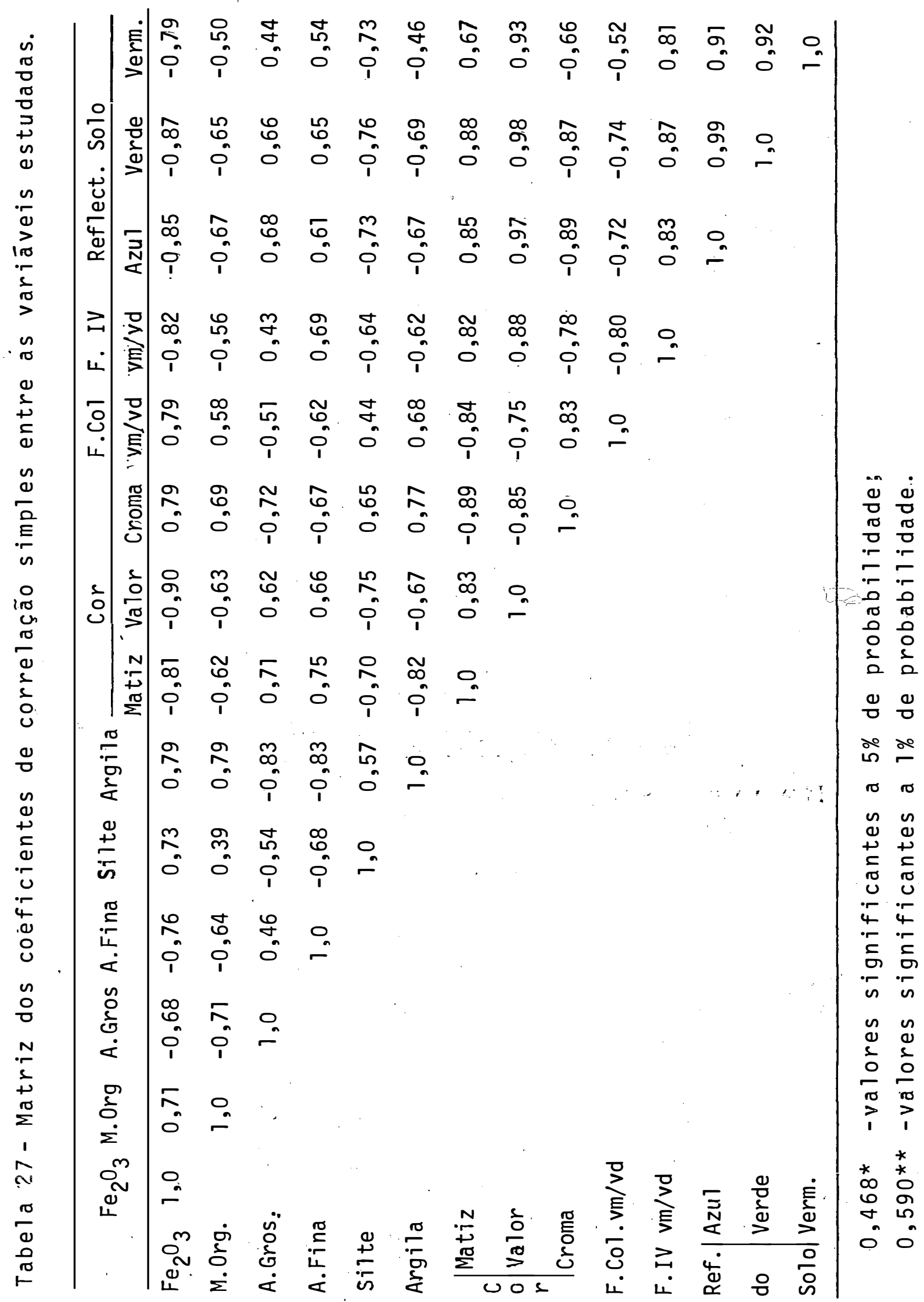




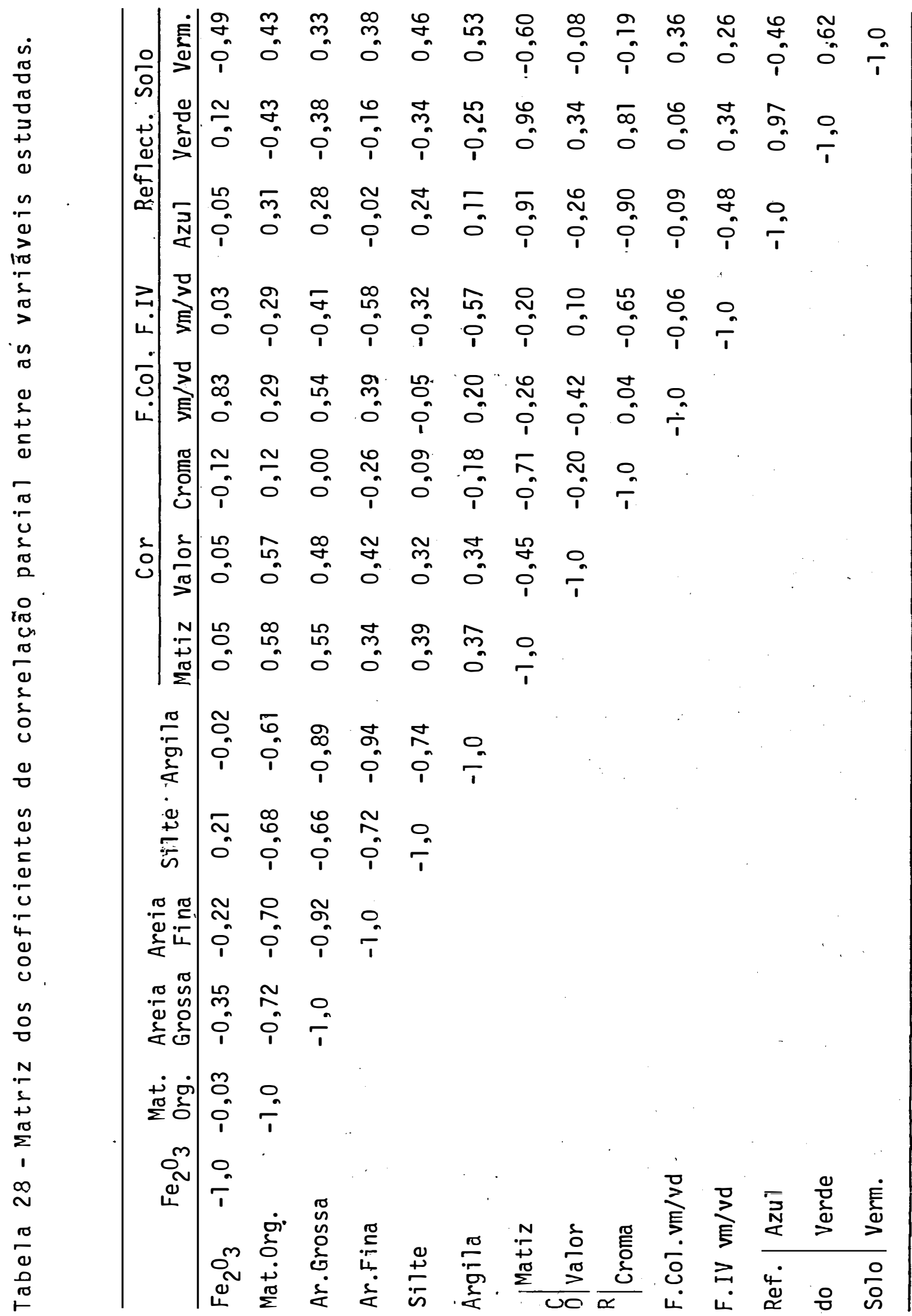


nadas das medidas densitométricas, os ōxidos de ferro livres e o teor de argila ou de matéria orgānica são as variáveis seguintes a integrarem as equações de regressão multipla. Assim, segundo as Tabelas 27 e 28 , tem-se:

Filtro vermelho

$$
\begin{aligned}
& \mathrm{Fe}_{2} \mathrm{O}_{3}: \mathrm{R} \text { simples }=-0,79 \\
& \text { Argila: } \mathrm{R} \text { parcial }=0,53
\end{aligned}
$$

Filtro verde

$$
\mathrm{Fe}_{2}{ }^{0}{ }_{3}: \mathrm{R} \text { simples }=-0,87
$$

Matēria orgânica: R parcial $=-0,43$

\section{Filtro azul}

$$
\mathrm{Fe}_{2} \mathrm{O}_{3}: \quad \mathrm{R} \text { simples }=-0,85
$$

Matēria orgânica: $R$ parcial $=0,31$

Estando a porcentagem de argila, assim como os. teores de óxidos de ferro, bastante correlacionados com a cor, na região do vermelho essas duas variāveis se sobressaem. Nas outras regiões do espectro visível, especialmente o verde, sobressai-se a matēria orgānica, como foi também observado por STONER e BAUMGARDNER (1979) e ADRIEN et alii (1982).

Entre as características físicas e químicas dos solos, excluindo-se a cor, são os ōxidos de ferro que apresentam.as maiores correlações lineares simples com a réflectância densitomëtrica. 
Quanto às classes de areia, os, coeficientes foram equivalentes, sendo que as medidas dos filtros azul e verde apresentaram maiores coeficientes significativos para areia fina e areia grossa.

Entre as medidas densitomëtricas em imagens aerofotogräficas, novamente as transparēncias infravermelhas coloridas apresentaram altos coeficientes de correlação com a reflectāncia densitomêtrica, superiores aos obtidos em imagens coloridas normais.

4.5. Relações entre as características dos solos estudados

Através da matriz de correlações simples da Tabela 27, que relaciona maior número de variāveis, pode-se verificar que parâmetros de solos, tais como ōxidos de ferro livres, cor, granulometria e matéria orgánica, exibem coeficientes de correlaçäó significativos com a reflectāncia densitométrica e registros tonais nas imagens, fato jā observado tambēm por numerosos autores como COSTA (1979), HOFFER e JOHANNSEN (1969), MYERS (1979), MATHEWS et alii (1973), PETERSON et alii (1979), PLANET (1970), STONER e BAUMGARDNER (1981), PAGE (1974), embora trabalhando com equipamentos e materiais diferentes.

As características estudadas, como matéria orgānica, argila e óxidos de ferro, apresentarám altas correlações com os componentes da cor, significativas ao nível de $1 \%$ 
de probabilidade, como foi tambēm observado por COSTA (1979) e por MCKEAGUE et alii (1971).

0 teor de óxidos de ferro foi a característica mais correlacionada à cor do solo e o matiz foi o componente da cor que apresentou os maiores coeficientes de correlação com as outras caracteristicas do solo.

Os valores de transmitáncia nas imagens aerofotogräficas apresentaram, no geral, altos coeficientes de correlação com as caracterĩsticas estudadas, mostrando-se bastante eficientes nadiscriminação das caracteristicas dos solos. Em relação ãs características do solo, pode-se dizer que houve uma equivalēncia dos dois tipos de imagens na discriminação do matiz e croma e uma ligeira vantagem à favor das transparências infravermelhas na discriminação do valor. Quanto às demais características, as medidas nos dois tipos de transparências apresentaram coeficientes de significância equivalentes, apenas se destacando o coeficiente entre silte e transmitāncia nas imagens infravermelhas. Esses resultados permitem, até certo ponto, comparação generalizada com trabalhos de outros autores que tambëm encontraram correlação significativa das características de imagens de diversos tipos na discriminação de solos; como MATHEWS et alii (1973), CARNEIRO e AZOLIM (1976), MYERS (1979), CIHLAR e PROTZ (1972), MAY e PETERSEN. (1975), KRISTOF e ZACHARY (1971). 
As conclusões de COSTA (1979), embora também constatadas por DONZELI (1979), , de que as leituras de cor em laboratörio mostraram-se eficientes na discriminação desse parâmetro, pela padronização dos procedimentos, foram novamente comprovadas nesta pesquisa. 


\section{CONCLUSOES}

Com a metodologia utilizada e face aos resultados obtidos e discutidos foi possîvel chegar-se às conclusões apresentadas a seguir.

os solos estudados apresentaram valores médios de espectros fotoacūsticos diferenciados, ao se levar em consideração os formatos das curvas obtidas. Porém, ao se considerar a amplitude de reflectāncia, a variabilidade dos dados foi alta, rão tendo sido possível detectar diferenças significativas entre os espectros representativos das i:unidades LRd e LE. 1 .

As razões espectrais entre faixas do visivel e do infravermelho eliminaram as diferenças relativas devidas apenas à amplitude de reflectância dos espectros, evidenciando melhor o comportamento espectral dos solos, considerando- se a forma das curvas.

As r.azões espectrais entre valores extremos da faixa estudada (450-500/800-900 nm) foram eficientes na dis- 
criminação entre os trés solos estudados, ao nível mínimo de 95\% de probabilidade.

0 estudo das imagens de transparēncias coloridas e infravermelhas não revelou diferenças significativas entre as unidades LRd e LE.l, até o nĩvel de 5\% de probabilidade, tendo sido possível discriminar, com facilidade, apenas a unidade LV.5 das outras duas.

As imagens de transparencias coloridas normais mostraram-se eficientes na discriminação entre cores dos horizontes superficiais de solos expostos.

A razão entre valores de reflectāncia do espectro fotoacústico nas regiões visivel/infravermelho ;mostrou-se altamente correlacionada com os teores de óxidos. de ferro, matiz e porcentagem de argila. Já a matéria orgânica, de maneira geral, apresentou menores coeficientes de correlação, na faixa estudada (450/900nm), com valores de reflectāncia do espectro fotoacústico.

Os parāmetros de solo, tais como óxidos de ferro, matēria orgānica, cor e granulometria, estão altamente relacionados com a reflectância densitométrica e registros de tonalidade nas imagens aerofotogräficas.

os teores de óxidos de ferro combinados com os de argila ou de matēria orgānica foram as variāveis indicadas para integrarem as equações de regressão mūltipla com a reflectāncia densitométrica, apresentando maior: significāncia nas seguintes faixas: 
Filtro vermelho: óxidos de ferro e argila;

Filtro verde: óxidos de ferro e matéria orgâni$\mathrm{ca}$;

Filtro azul: óxidos de ferro e matēria orgānica.

Entre.as características físicas e quĩmicas dos solos, excetuando-se a cor, foram os óxidos de ferro que se apresentaram mais altamente correlacionados à reflectāncia densitométrica relativa.

As cores Munsell/densitométricas dos solos mostraram-se altamente correlacionadas com os teores de matéria orgānica, argila e óxidos de ferro.

As imagens aerofotogrāficas estudadas, assim como a anālise de espectroscopia fotoacústica e de reflectāncia densitométrica, mostraram-se eficientes na discriminação dos solos, quando a cor e demais características dos solos ...

a ela associadas são características discriminantes entre as unidades pedológicas. 


\section{LITERATURA CITADA}

AL-ABBAS, A.H., P.H. SWAIN e M.F. BAUMGARDNER, 1972. Relating organic matter and clay content to the multispectral radiance of soils. Soil Sci. Baltimore, 114(6):477-485.

ADRIEN, P.M., M.F. BAUMgardner C.B. BROWN e J.B. PETERSON, 1982. Characteristic variations in reflectance of saline and alkaline soils of the Bolivian altiplano. LARS. Technical report 120582. West Lafayette, 59p.

ALMEIDA, F.F.M., 1964. Fundamentos geológicos do relevo paulista. Bol. Inst. Geogr. Geol. São Paulo, 41: 167-262.

AMARAL, A.Z. e AUDI, R., 1972. Fotopedologia. In: MONIZ, A.C. Elementos de Pedologia. São PauTo. Editora USP. 35: 429-442. AMARAL, G. 1975. Sensores remotos - aplicações em geociências São Paulo, Instituto de Geociēncias. USP. 114 p. ANSON, A., 1968. Developments in aerial color photography Photogram. Eng., Fal1s Church 34: 1048-1057. 
ANSON, A., 1970. Color aerial photos in the reconaissance of soils and rocks. Photogram. Eng., Falls church, 36:343-354. BAUGMGARDNER, M.F,, S.J. KRISTOF, C.J. JOHANNSEN E A.L. ZACHARY: 1970. Effects of organic matter on the multispectral properties of soils. Indiana Academy of Science. 79: $413-422$.

BOWERS, S.A e R.J. HANKS, 1965. Reflection of radiant energy from soils. Soil Sci. Baltimore, 100: 130-138.

BROONER, W.G. A D.S. SIMONETT, 1971. Crop descrimination with color infrared photography: a study in Douglas, Kansas. - Remote Sensing of Environment, New York, 2: 21-35.

CARNEIRO, M.R. e M.A.D. AZOLJN, 1976. Utilização de imagens MSS do ERTS-1 em levantamentos de solos em comparação com fotografias aéreas verticais. Rev. Centro de Ciências Rurais. Sta. Maria R.S. 5(1): 55-66.

CARROLL, D.M., 1973a. Remote Sensing techniques and their application to soil science: Part I - The Photographic sensors. Soil and Fertilizers. Harpender, 36(7): 259-266.

CARROLL, D.M., 1973b. Remote Sensing techniques, and their application to soil science: Part II - The non photographic sensors. Soil and fertilizers. Harpender, 36(8): 313-320.

CHIARINI, J.V. e A.G.S. COELHO, 1969. Cobertura vegetal natural e ārea reflorestada no Estado de São Paulo,' Bol. Inst. Agronômico 193. Campinas, $35 \mathrm{p}$. 
CIHLAR, J. e R. PROTZ, 1972. Color-film densities for soils. Photogram. Eng.,Falls Church, 38: 1091-1098.

CIHLAR, J. e R. PROTZ, 1973. Surface characteristics of mapping units related to aerial imagery of soils. Can.J. Soil Sci. Ottawa, 53: 249-257.

CIPRA, J.E., M.F: BAUMGARDNER, E.R. STONER P R.B. MACDONALD, 1971. Measuring radiance characteristics of soil with a field spectroradiometer. Soil Sci. Soc. Amer. Proc., Madison, 35 : $1014-1017$.

CIPRA, J.E., D.P. FRANZMEIER, M.E. BAUER e R.K. BOYD, 1980. Comparison of multispectral measurementes from some nonvegetated soil using LANDSAT digital data and a spectroradiometer. Soil Sci. Soc. Am. J., Madison, 44: 80-84.

COLWELL, R.N.; 1966. Uses and 1imitations of multispectral remote sensing. Proc. Symp. on Remote Sensing of the Environment, 4 th. Ann Arbor, 1: 71-100.

CONDIT, H.R., 1970. The espectral reflectance of american soils. Photogram. Eng. Am. Soc. Photogram.,Falls Church. $36(9): 955-965$.

COSTA, L.M., 1979. Surface soil color and reflectance as related to physico-chemical and mineralogical soil properties. Columbia, Univ. of Missouri, 154 p. (Ph.D. Thesis).

CROWN, P.H. e S. PAWLUK, 1974. Spectral signatures from selected soils in the Edmonton Vegreville Area. In: Second Canadian symposium on remote sensing. Guelph, II: 449-462. 
DOMINGUES, 0., 1960. Comparative analysis of color and blackand-white aerial photography as aids in the mapping of soils in wildland areas. In: Manual of Photographic Interpretation 5: 398-402.

DONZELI, P.L., 1979. Densitometria em aerofotografias coloridas normais e infravermelhas relacionada às caracteristicas das cores de trés latossolos. Dissertação de Mestrado Piracicaba, ESALQ. USP. $84 \mathrm{p}$.

DRAPER, N.R. e H. SMITH, 1966. Applied Regression Analysis. New York, John Willey \& Sons, Inc, $407 \mathrm{p}$.

EASTMAN KODAK COMPANY, 1972. Properties of Kodak materials for aerial photographic systems. Vol. 1 - Kodak aerial films and photographic plates. Rochester, Profissional, Comercial and Industrial Markets Division. $75 \mathrm{p}$.

ESTES, J.E. e D.S. SIMONETT, 1975. Fundamentals of image, interpretation. In: REEVES, R.G., Ed. Manual of remote sensing. Falls Church, American Society of Photogrammetry, 2: $869-1076$.

EVANS, R., 1979. Air photos for soil survey in Lowland England: Factors affecting the photographic images of bare soils and their relevance to assessing soil moisture content and discrimination of soils by remote sensing. Remote Sens. Environm. New York, 8: 39-65.

EVANS, R., J. HEAD e M. DIRKZWAGER, 1976. Air photo-tones and soil properties: Implications for interpreting satellite imagery. Remote Sens. Environ., New York, 4: 265-280. 
FORMAGGI0, A.R., 1983. Comportamento espectral de quatro solos do Estado de São Paulo nos níveis orbital, de campo e de laboratōrio. São José dos Campos, INPE, $91 \mathrm{p}$. (Tese de Doutoramento).

FORSGARD; F.C. E C.M. WHITTEMORE, C.M., 1968. Color Aerial Films. In: Manual of Color: Aerial Photography Am. Soc. of Phot.,Falls Church, IV: 196-208.

FRANÇA, G.V., 1968. Interpretação fotogrāfica de bacias e de redes de drenagem aplicada a solos da região de Piracicaba. Piracicaba, ESALQ/USP, 151 p. (Tese de Doutoramento). GARCIA, G.J., 1975. Fotointerpretação comparativa de fotografias pancromàticas, coloridas e infravermelhas coloridas (falsa cor). Piracicaba. ESALQ/USP, 111 p. (Tese de Doutoramento).

GARCIA, G,J., E D.A.B. MARCHETTI, 1977. Fotointerpretação da vegetação através da densitometria. Anais da ESALQ. Piracicaba, 34: 275-279.

GROHMANN, F. e B. VAN RAIJ, 1974. Influēncia do método de agitação na dispersão de argila do solo. In: Congresso Brasileiro de Ciencia do Solo, 14, Santa Maria, RS, p. 123-132. HELLER, R.C., 1971. Imaging with photographic Sensors. In: Remote Sensing. Nat. Academy Sci. Wastington, DC. p. 3572.

HOFFER, R.M. e C.J. JOHANNSEN: 1969. Ecological Potentials in spectral signature analysis. In: Purdue University, LARS. 
Remote Sensing tecnology and applications. Lafayette p. 1-26 (LARS Print 011069-R).

HOFFER, R.M., P.E. ANUTA e T.L. PHILLIPS, 1972. Automatic data processing multiband and multiemulsion digitalized photos. Photogram. Eng., Falls Church, 38(10): 989-1001.

INPE. INSTITUTO DE PESOUUISAS ESPACIAIS, 1975. Banco de Dados Bol. divulgaçâo. São Josē dos Campos, 1(9): 28-37.

INSTITUTO GEOGRĀFICO E GEOLOGICO, 1974. Mapa Geøégic• do Estado de Sã. Paul, Escala 1:1.000.000. São Paulo, $1 \mathrm{f}$. JACKSON, M.L., 1956. Soil Chemical Analysis. Madison, Wis., 864 f. (mimeografado).

KOFFLER, N.F., 1982. Identificação da cultura da cana-de- açucar (Saccharun spp.) atravēs de fotografias aéreas infravermelhas coloridas e dados multispectrais do satélite LANDSAT. Piracicaba, ESALO/USP, 233 p. (Tese de Doutoramento ).

KRISTOF, S.J., 1971. Preliminary multispectral studies of soils. J. Soil and water Cons., Ankeny, 26: 15-18.

KRISTOF, S.J. e A.L. ZACHARY, 1971. Mapping soil features from multispectral scanner data. Photogram. Eng., Falls Church, $40(12): .1427-1434$. 
KRJSTOF, S.J., M.F. BAUMGARDNER, R.A. WEISMILLER e S. DAVIS, 1980. Application of multispectral reflectance studies of soils: Pre-Landsat. Proc. Symp. Mochine Processing of Remotely Sensed Data, 6 th. West Lafayette, II: 52-61.

KUHL, A.D., 1970, Color and IR photos for soils. Photogram. Eng., Falls Church 36: 475-482.

LUEDER, D.R., 1959. Aerial photographic interpretation, principles and applications. New York, Mc Graw-Hill, 462 p.

MACE, T.H., 1980. Digital microdensitometric analysis of aerial photographic imagery for detailed soils mapping. Proc. Symp. Machine Processing of Remotely Sensed Data, 6 th. West Lafayette, II: 224-229.

MARCHETTI, D.A.B. e G.J. GARCIA, 1978. Princípios de botogrametria e fotointerpretação: Livraria Nobel, São Paulo, 257 p. il.

MATHEWS, H.L., R.L. CUNNINGHAN e G.W. PETERSEN: 1973. Spectral reflectance of selected Pennsylvania soils. Sail Sci. Soc. Amer. Proc., Madison, 37: 421-424.

MAY, G.A. e W. PETERSEN, 1975. Spectral signature selection for mapping unvegetated soils. Remote Sens. Environ., New York 4: 211-220. 
MCKEAGUE: J.A., J.H., DAY e J.A. SHIELDS, 1971. Evaluating relationships among soil properties by computer analysis. Can J. Soil Sci. Ottawa, 51: 105-111.

MEDINA, H.P. e F. GROHMANN, 1962. Contribuição ao estudo da anālise granulométrica do solo. In: Congresso Brasileiro de Ciência do Solo, 6., Salvador, BA, Anais. Rio de Janeiro, p. 29-38.

MONTGOMERY, 0.L., 1974. The effects of physical and chemical properties of soil on the spectral reflectance of soils. West Lafayette, Purdue Uni. LARS, 110 p. (M.S. Thesis).

MONTGOMERY, O.L., M.F. BAUMGARDNER e R.A. WEISMILLER, 1976. An investigation of the relationship between spectral reflectance and the chemical, physical and genetic characteristics of soils. West Lafayettte, LARS, Purdue University. $147 \mathrm{p}$.

MOREIRA-NORDEMANN, L.M., L.A.M. LUCHT E R.P.A. MUNIZ, 1983. Photoacoust spectroscopy and surface temperature measurements of tropical soils. INPE-2853 - PRE/393 (relatōrio interno), São José dos Campos, S.P. 39 p.

MYERS, V.I., 1979. Crops and soils In: Manual of Remote Sensing. Am. Soc. Photogram., Falls Church. 2(22): 1.715-1813. MYERS: V.I. e W.A. ALLEN: 1968. Eletrooptical remote sensing methods as non-destructive testing and measuring techniques in agriculture. Appl. Optics. 7(9): 1819-1838. 
OLIVEIRA, J.B. e C.L. RotTA, 1973. Levantamento pedológico detalhado da Estação de Limeira. Bragantia. Campinas; $32(1): 1=60$.

OLIVEIRA, J.B., J.R.F. MENK, J.L. BARBIERI, C.L. ROTTA e W. TREMOCOLDI, 1982. Levantamento pedológico semidetalhado do Estado de São Paulo: Quadrícula de Araras. Bol. Téc. Inst. Agronômico 71. Campinas, $180 \mathrm{p}$.

PAGE, N.R., 1974. Estimation of organic matter in Atlantic Coastal plain soils with color-difference meter. Agronomy J., Madison, 66: 652-653.

PARKS, W.L. e R.E. BODENHEIMER, 1973, Delineation of major association using ERTS-1 imagery. In: NASA. Symposium on significant results obtained from the earth resources technology satellite-1. New Carrollton, 1: 121-126.

PARRY, J.T., J.A. HEGINBOTTON e W.R. COWAN, 1969. SOil studies with color photos. Photogram. Eng., Falls Church, 35: $44-56$.

PENTEADO, M.M., 1968. Geomorfologia do setor centro-ocidental da Depressão Periférica Paulista. Rio Claro, FFCL/UNESP, 160 p. (Tese de Doutoramento).

PETERSON, J.B., R.H. BECK e B.F. ROBINSON, 1979. Predictability of change in soil reflectance on wetting. Proc. Symp. Machine Processing of Remotely Sensed Data, 5 th. West Lafayette, I: 264-273. 
PIECH, R.K. e J.E. WALKER, 1974. Interpretation of soils. Photogram. Eng. Am. Soc. Photogram. 40(1) 87-94.

PLANET, W.G., 1970. Some coments on reflectance measurements of wet soils. Remote Sensing of Environment. New York; $1: 127-129$.

RAY, R.G.; 1963. Fotografias aēreas na interpretação e mapeamento geológico. Tradução. São Paulo, Inst. Geogr. e Geol. $88 \mathrm{p}$.

RIB, H.T., 1968, Color measurements. In: SMITH JUNIOR, J.T., Ed. Manual of color aerial photography. Falls Church, American Society of Photogrammetry, p. 12-24.

RICCI, M. e S. PETRI, 1965. Principios de aerofotogrametria e interpretação geolögica. São Paulo. Editora Nacional. 226 p.

ROSENCWAIG, A., 1977. Solid state photoacoustic spectroscospy. In: YOH-HAN PAO. Fotoacoustic spectroscopy and detection. $\because$ Academic Press, New York. 8: 193-239.

SCARPACE, F.L., 1978. Densitometry on multi-emulsion imagery. Photogram. Eng. and Remote Sens., Falls Church, 44: 12791292 .

SCARPACE, F.L. e G.A. FRIEDERICHS, 1978. Method of determining spectral analitical dye densities. Photogramm. Eng. and Remote Sens. Falls Church, 44: 1293-1297.

STEZER, J., 1966. Átlas Climātico e Ecológico do Estado de São Paulo. São Paulo, Comissão Interestadual da Bacia Paranā - Uruguai, $61 \mathrm{p}$. 
SOIL SURVEY STAFF, 1975. Soil taxonomy-A basic system of soil classification for making and interpreting soil survey. Handb. n. 436, US Government Printing Office, Washington, DC, $754 \mathrm{p}$.

STEINER, D. e H. HAEFNER, 1965. Tone distortion for automated interpretation. Photográm. Eng.,Falls Church, 31.(2): 269-280.

STONER, E.R. e E.H. HORVATH, ]978. The effect of cultural practices on multispectral response from surface soil. LARS Technical Report 022278. West Lafayette, p. 2109-2113.

STONER, E.R. e M.F. BAUMGARDNER, 1981. Characteristic variations in reflectance of surface soils. Soil Sci. Soc. Am. J., Madison, 45(6): 1161-1165.

STONER, E.R., M.F. BAUMGARDNER, L.L. BIEHL e B.F. ROBINSON, 1980. Atlas of soil reflectance properties. Agricultural Experiment Station, Purdue University, Research Bulletin 962. West Lafayette, $20 \mathrm{p}$.

StRANDBERG, C.H., 1968. The language of color. In: Manual of color aerial photography - Am. Soc. Photogram., Falls Church;' $1: 3-12$.

TARKINGTON, R.G. e A.L. SOREM, 1963. Color and false color films for aerial photography. Photogram. Eng., Falls Church, $29(1): 88-95$.

VALENTJNE, K.W.G., T.M. LORD, W. WATT e A.L. BEDWANY, 1971, Soil mapping accuracy from black and white, color and infrared aerial photography. Can. J. Soiè sci., ottawa, 51: 461-469. 
VALERIO FILHO, M., N.T. Higa e V.C. CARVALHO, 1976. Avaliação das imagens orbitais (LANDSAT-1) como base para levantamento de solos. São José dos Campos, INPE/CNPq, 247 p. (Dissertação de Mestrado).

VAN RAIJ, B. e M.A. TEIXEJRA ZULL.0, 1977. Métodos de anālise de solo: Circular nọ 63, Inst. Agron. Estado de São Paulo. Campinas, SP, $16 \mathrm{p}$.

VANDERBILT, V.C., E.R. STONER, L.L. BIEHL, B.F. ROBINSON, R . A. WEISMILLER e M.E. BAUER, 1980. Fine structure in the spectral reflectance of vegetation and soils. Proc. Symp. Machine Processing of Remotely Sensed Data, $\therefore 6$ th., West Lafayette, II : $358-365$.

WESTIN, F.C. e C.J. FRAZEE, 1976. Landsat data, its use in a soil survey program. Soil Sci. Soc. Am. J., Madison, 40: $81-89$.

WEISMILLER, R.A. e S.A. KAMINSKY, 1978. Application of remote-sensing technology to soil survey research. J. Soil and water Conserv., Ankeny, 33(6): 287-289. 


\section{APENDICES}

Apēndice 1 - Anālise de características físicas e quĩmicas das amostras das trēs unidades de solo estudadas.

Apêndice 2 - Densidade ótica (Dx100) das amostras de solo (TFSA).

Apêndice 3 - Densidade ótica (Dx100) das imagens coloridas normais.

Apēndice 4 - Densidade ótica (Dx100) das imagens coloridas infravermelhas.

Apēndice 5 - Espectros ōticos de absorção obtidos por espectroscopia fotoacústica para as amostras das unidades de solo estudadas. 
Apēndice 1 - Anālise de características fî́sicas e quỉmicas das amostras das três unidades de solo estudadas.

\begin{tabular}{|c|c|c|c|c|c|c|c|}
\hline \multirow[b]{2}{*}{ Solo } & \multirow{2}{*}{ Amostra } & \multirow{2}{*}{$\% \mathrm{Fe}_{2} \mathrm{O}_{3}$} & \multirow{2}{*}{$\begin{array}{l}\text { Mat.Or- } \\
\text { gãnica } \\
\text { em Volume }\end{array}$} & \multicolumn{3}{|c|}{ Granulometria } & \multirow{2}{*}{ Argila } \\
\hline & & & & $\begin{array}{l}\text { Areia } \\
\text { Grossa }\end{array}$ & $\begin{array}{l}\text { Areia } \\
\text { Fina }\end{array}$ & Silte & \\
\hline \multirow{6}{*}{ LRd } & 3.1 & 15,06 & 5,69 & 4,25 & 21,65 & 7,65 & 66,45 \\
\hline & 3.2 & 16,22 & 6,07 & $2 ; 20$ & 22,40 & 8,35 & 67,05 \\
\hline & 3.3 & 14.54 & 5,12 & 3,55 & 16,70 & 11,05 & 68,70 \\
\hline & 3.4 & 10,25 & 5,31 & 4,90 & 24,70 & 11,30 & 59,10 \\
\hline & 3.5 & 8,76 & 4,64 & $11, \widehat{25}$ & 30,20 & 6,95 & 51,60 \\
\hline & 3.6 & 9,60 & 4,33 & 21,50 & 35,70 & 4,45 & 38,35 \\
\hline \multirow{6}{*}{ LE. 1} & 2.1 & 8,31 & 6,07 & 5,05 & 21,35 & 1,80 & 71.80 \\
\hline & 2.2 & 9,86 & 4,81 & 4,45 & 29,50 & 5.70 & 69.35 \\
\hline & 2.3 & 11,94 & 6,70 & 4,35 & 20,75 & 6,95 & 67.95 \\
\hline & 2.4 & 11,62 & 6,28 & 6,15 & 24,55 & 6,70 & 62,60 \\
\hline & 2.5 & 10,45 & 5,12 & 10,35 & 20,15 & 8.45 & 61,05 \\
\hline & 2.6 & 10,58 & 4,56 & 3,90 & 27,45 & 11,05 & 57,60 \\
\hline \multirow{6}{*}{ LV. 5} & 1.1 & 4,61 & 4,71 & 17,90 & 30,80 & 6,80 & 44,50 \\
\hline & 1.2 & 4,41 & 4,51 & 4,15 & 55,10 & 1,55 & 39,20 \\
\hline & 1.3 & 1,62 & 3,30 & 30,05 & 33,65 & 1,10 & 35,20 \\
\hline & 1.4 & 2,66 & 4,23 & 20,60 & 45,40 & 0,90 & 33,10 \\
\hline & 1.5 & 3,31 & 4,64 & 5,55 & 35,25 & 3,95 & 55,25 \\
\hline & 1.6 & 2,47 & 4,23 & 22,95 & 44,15 & 3,40 & 29,50 \\
\hline
\end{tabular}




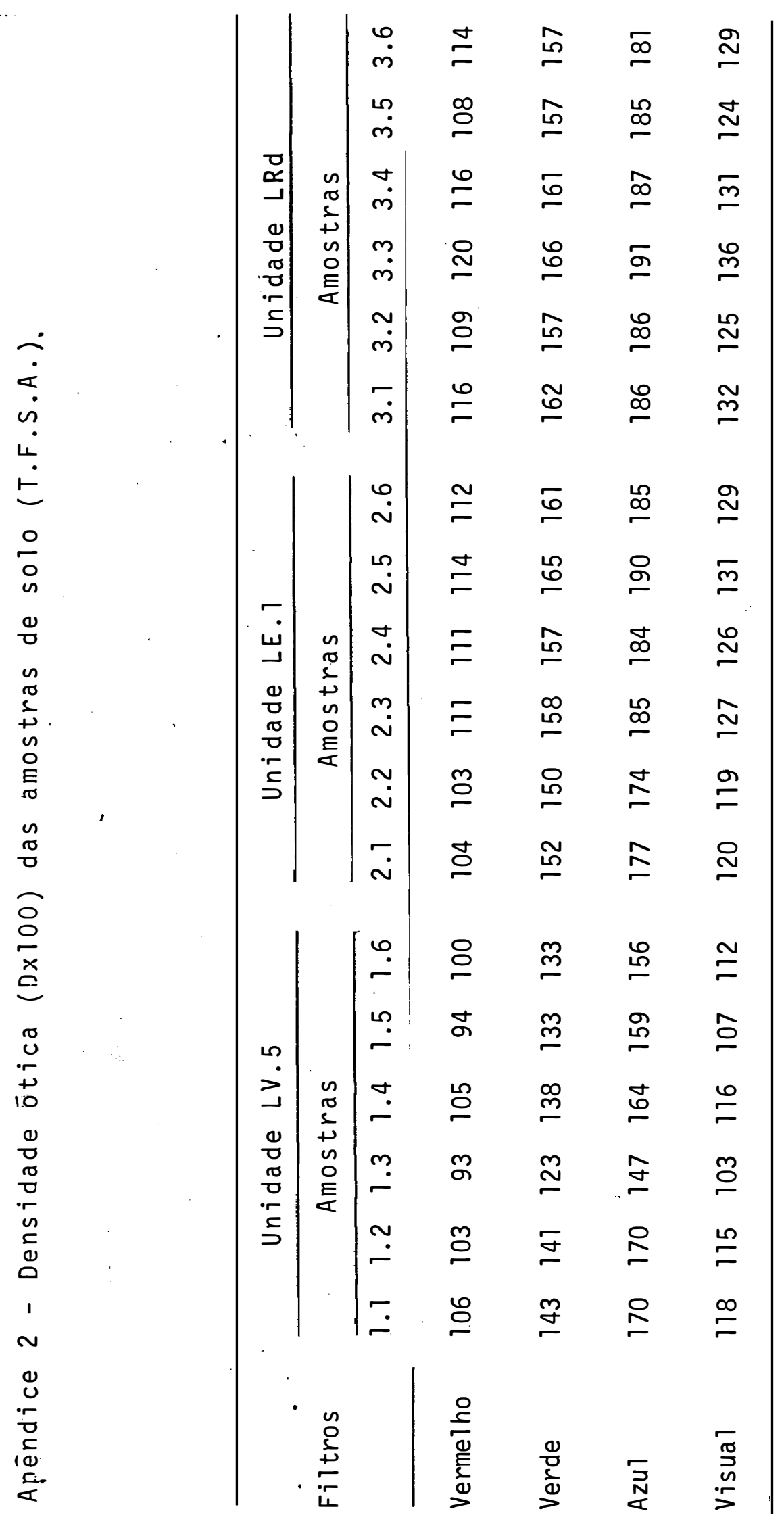




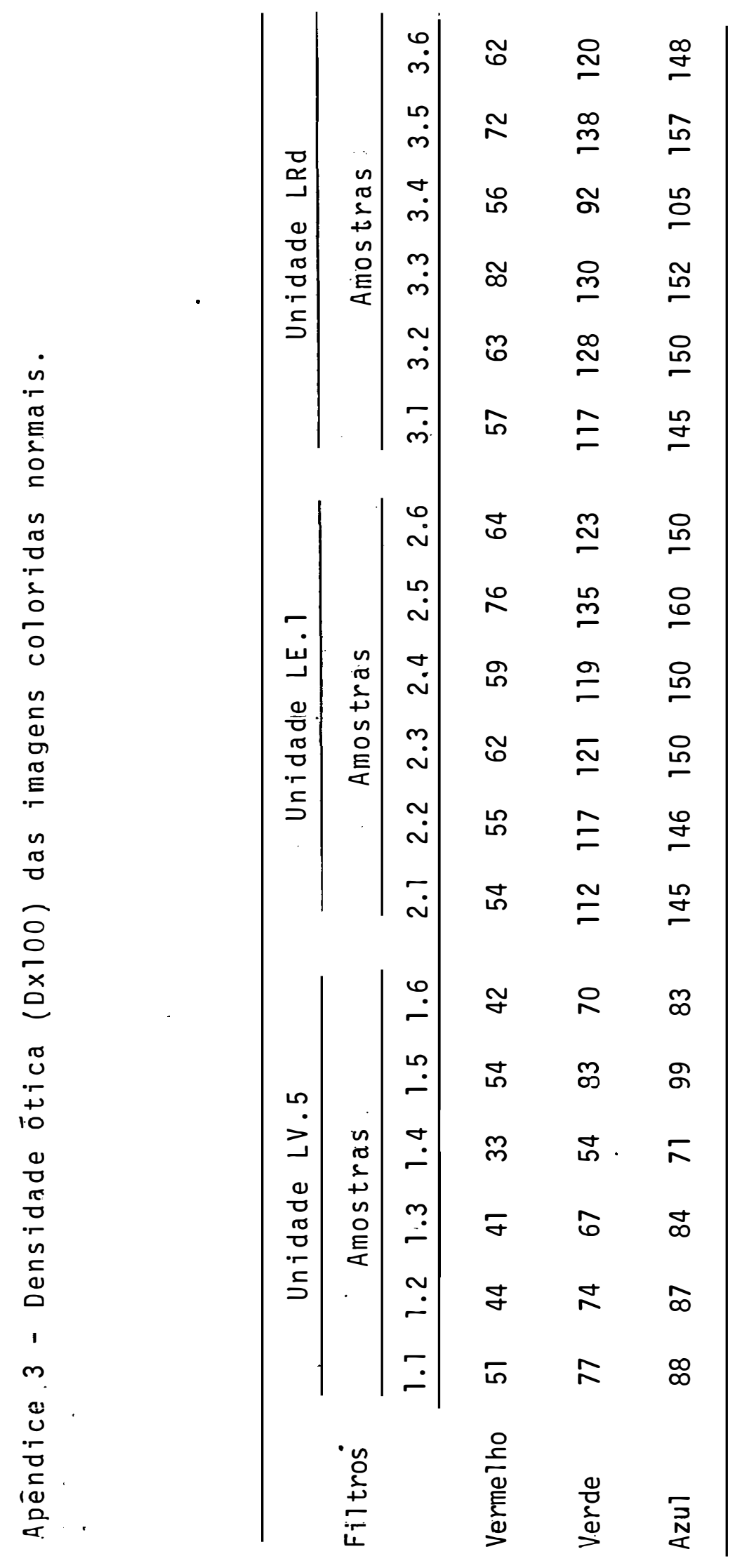




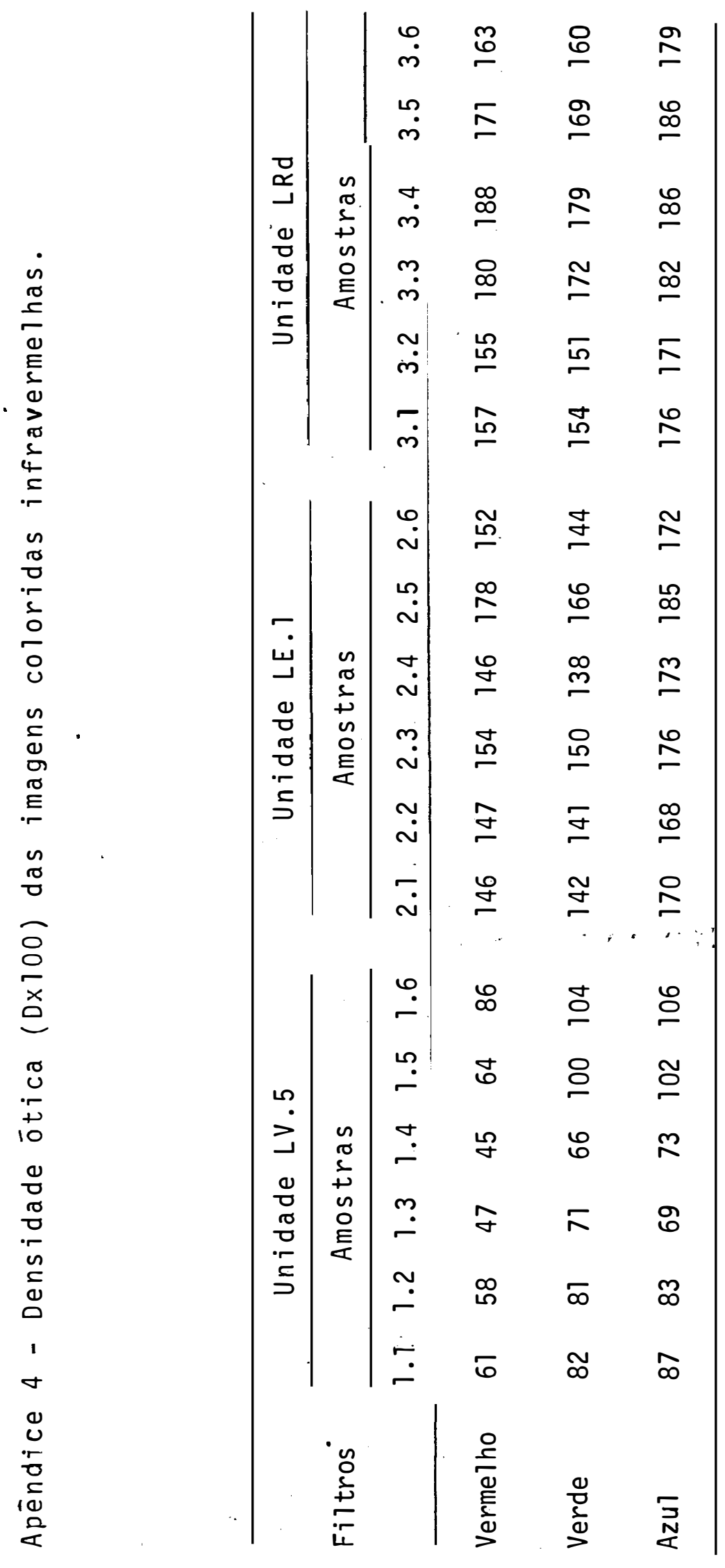




\section{APENDICE - 5}

Espectros öticos de absorção obtidos por es-

pectroscopia fotoacustica para as amostras das unidades de solo estudadas. 


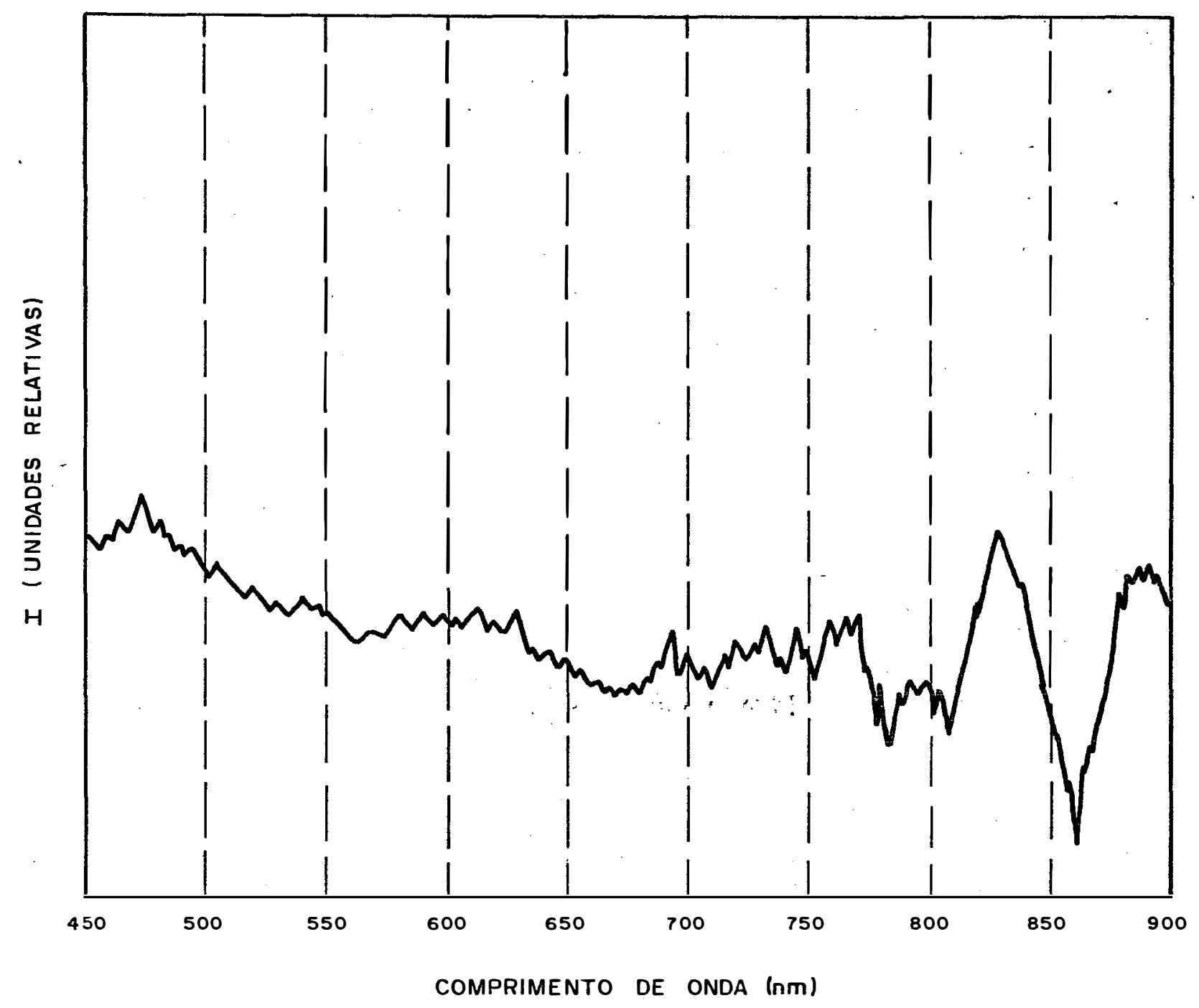

Amostra 1.1 - Unidade LV.5 - Mato Dentro. 


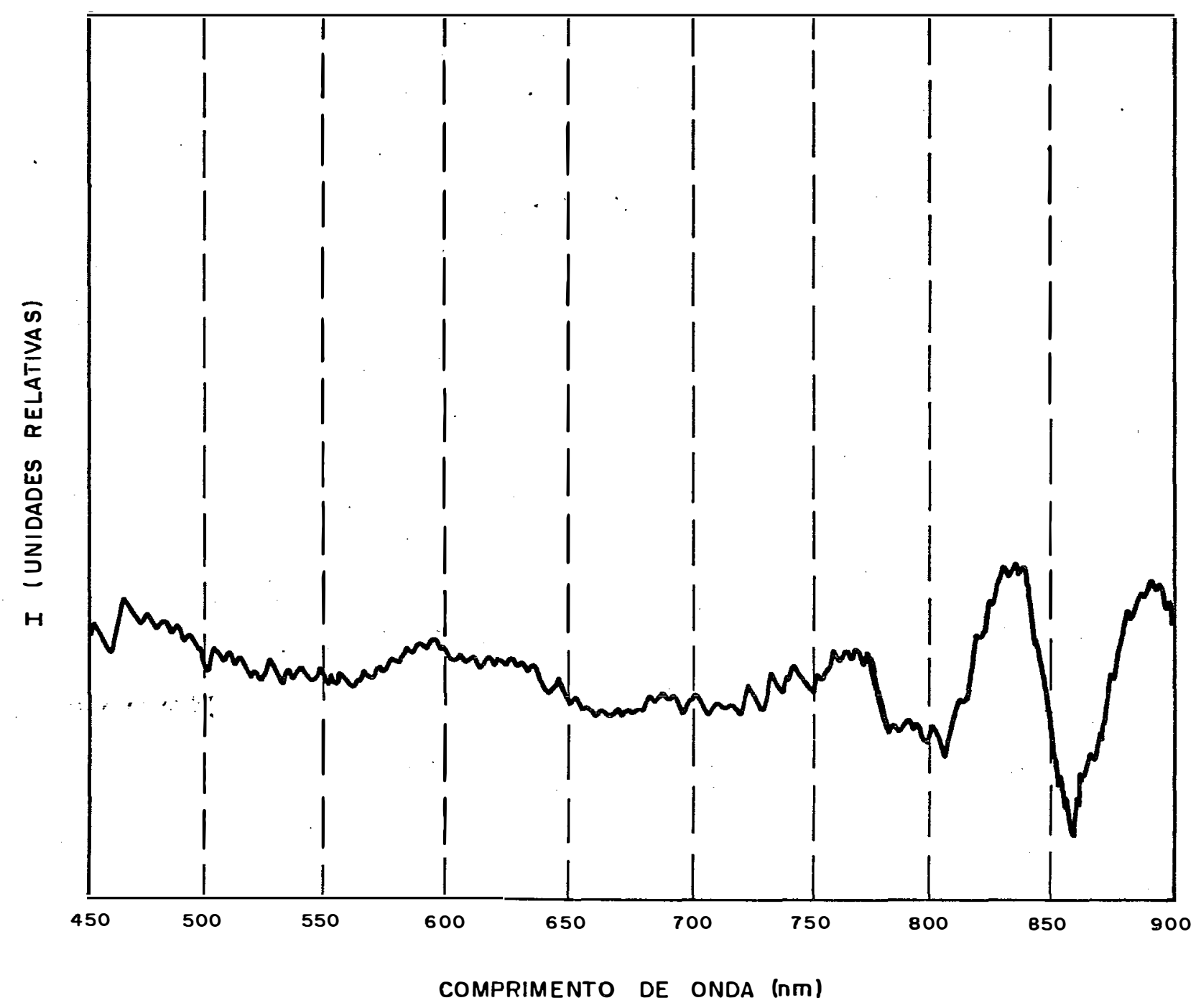

Amostra 1.2 - Unidade LV.5 - Mato Dentro. 


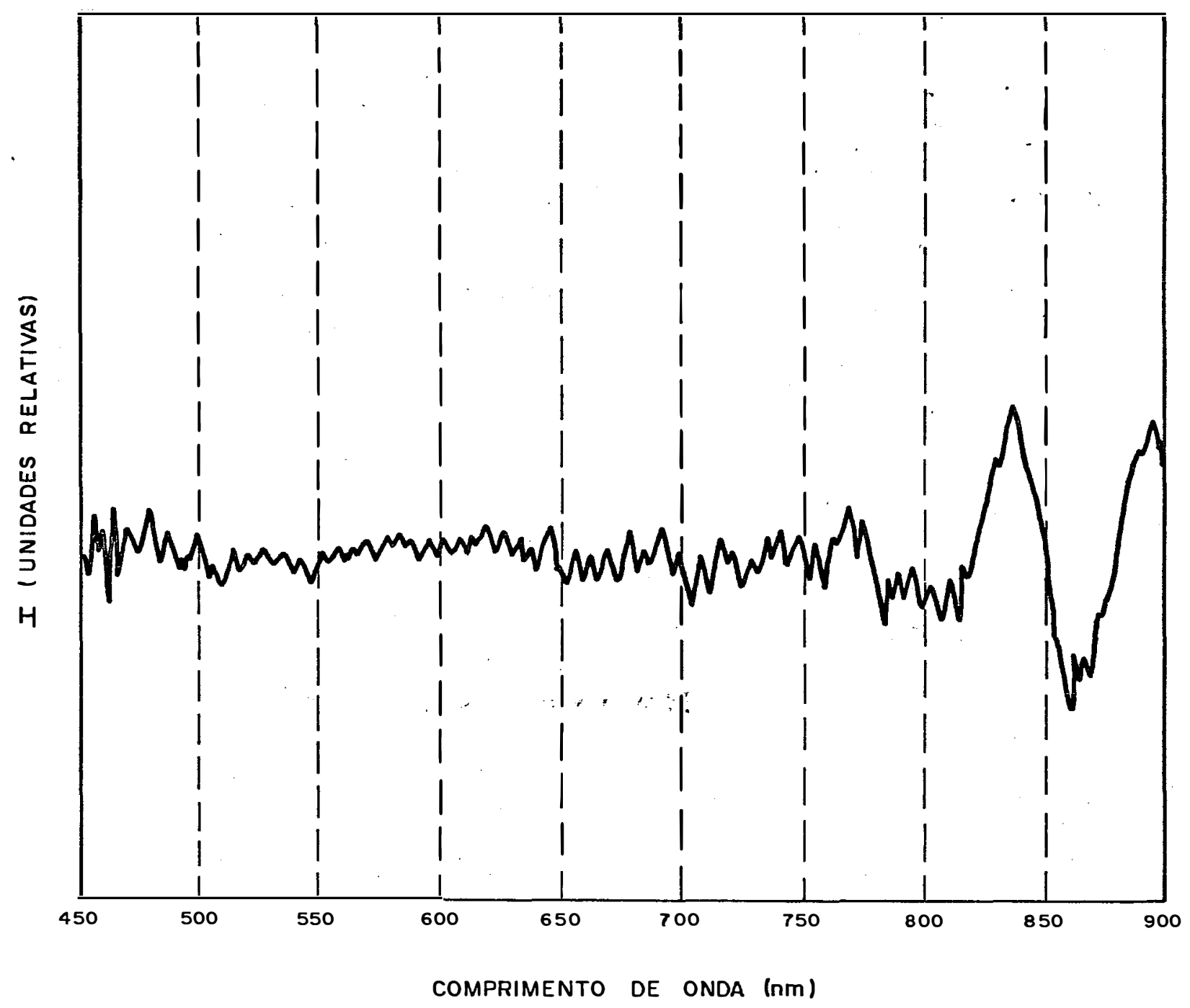

Amostra 1.3 - Unidade LV.5 - Mato Dentro. 


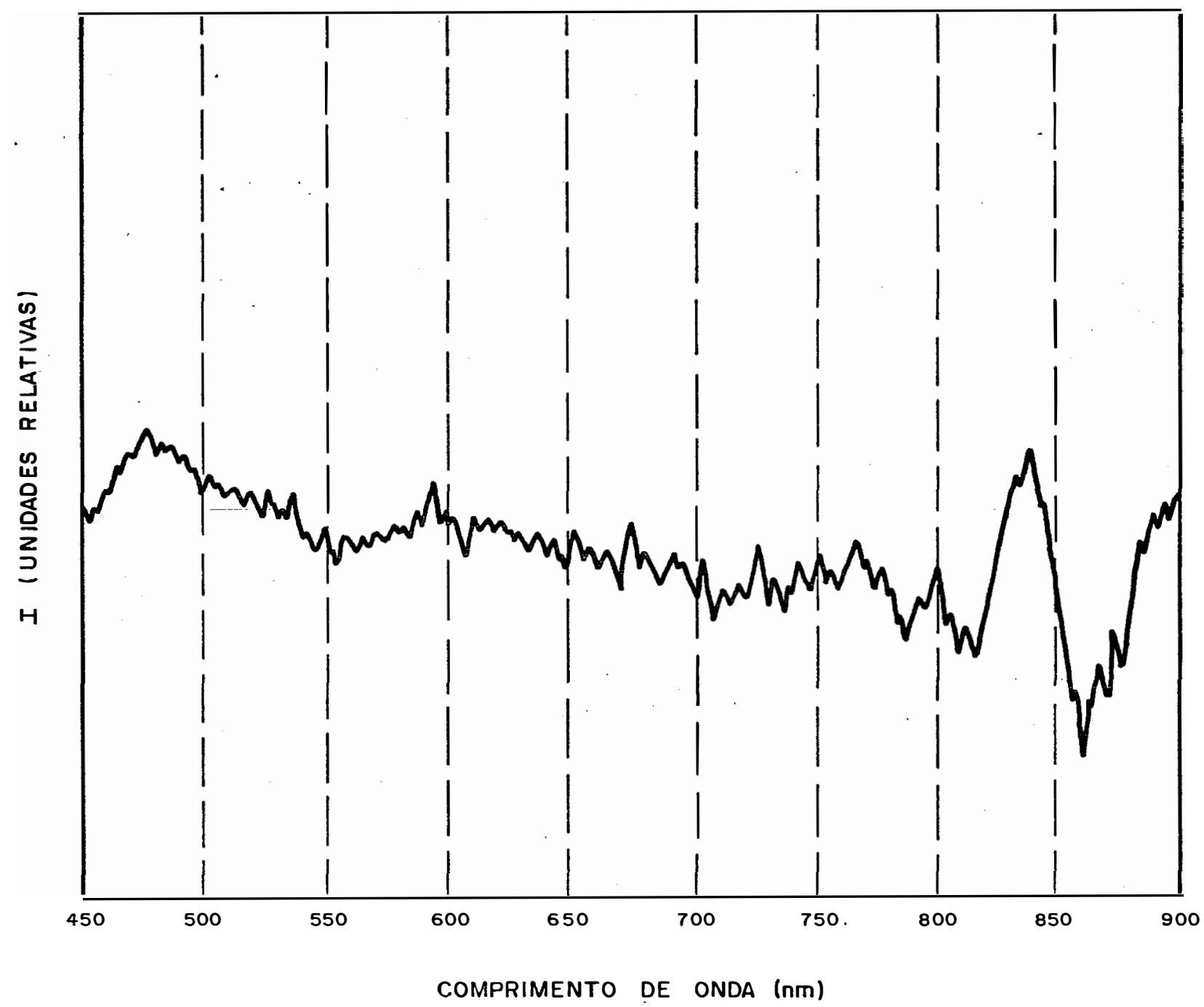

Amostra 2.1 - Unidade LE.1 - Limeira. 


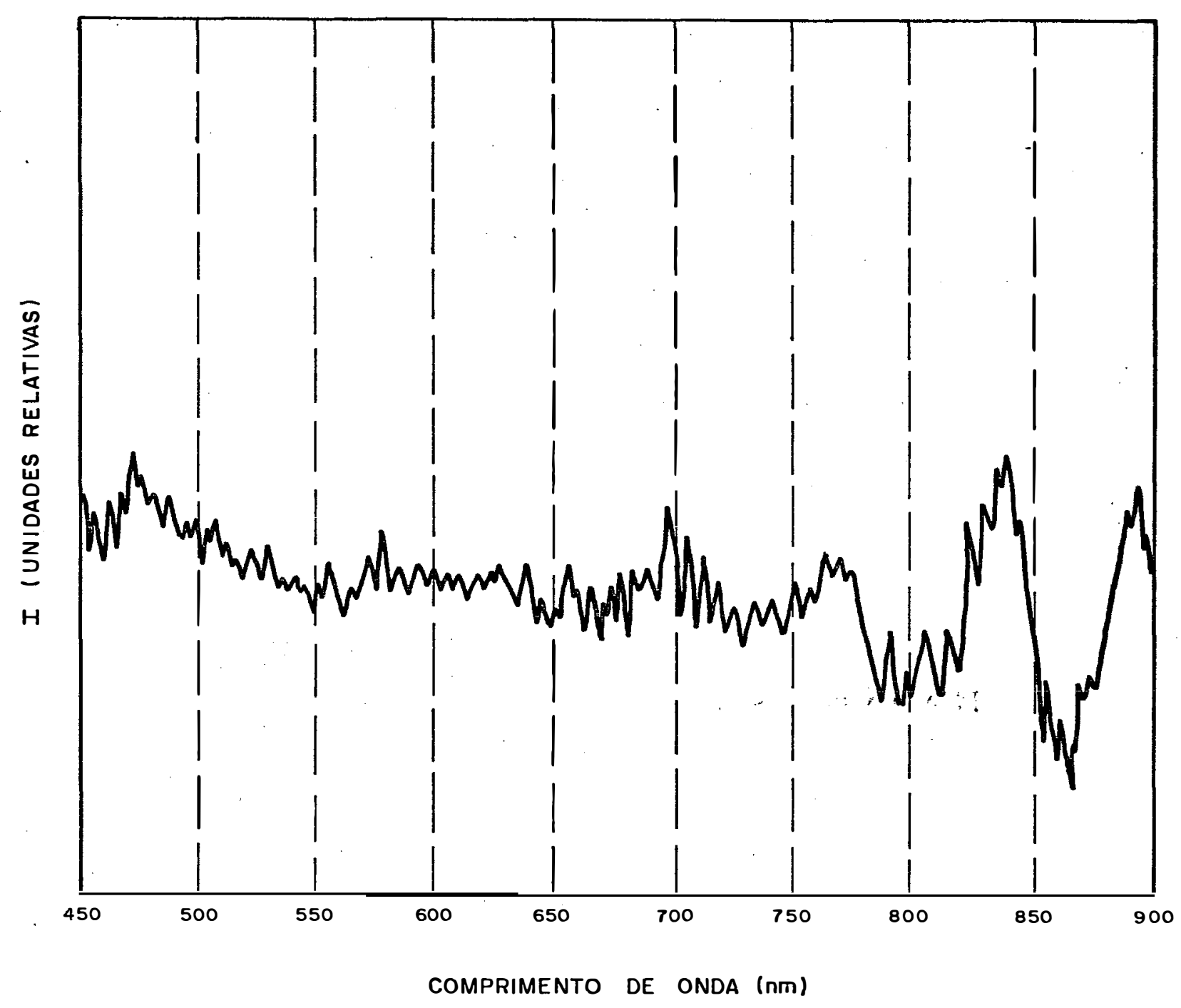

Amostra 2.2 - Unidade LE.1 - Limeira. 


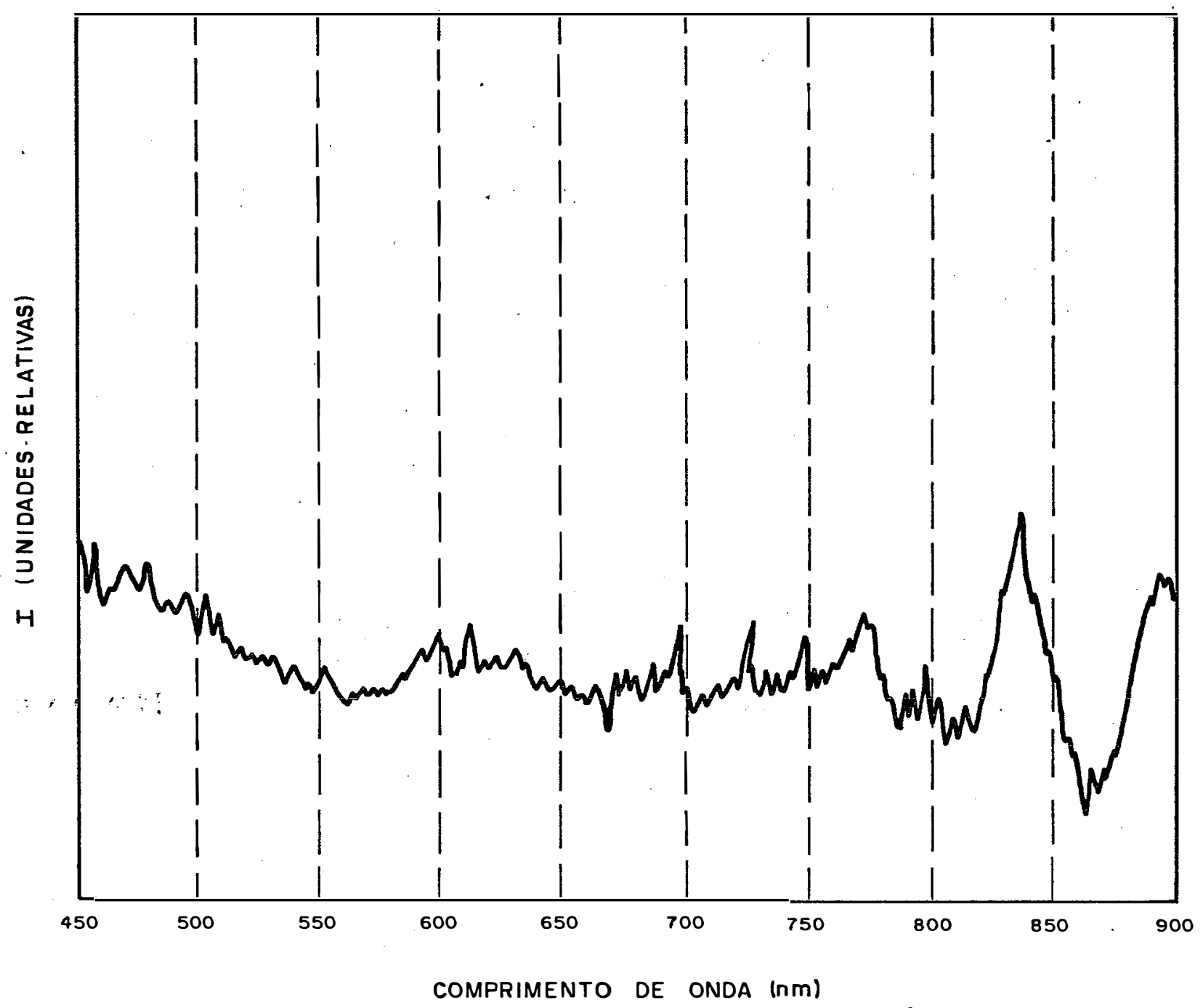

Amostra 2.3 - Unidade LE.1 - Limeira. 


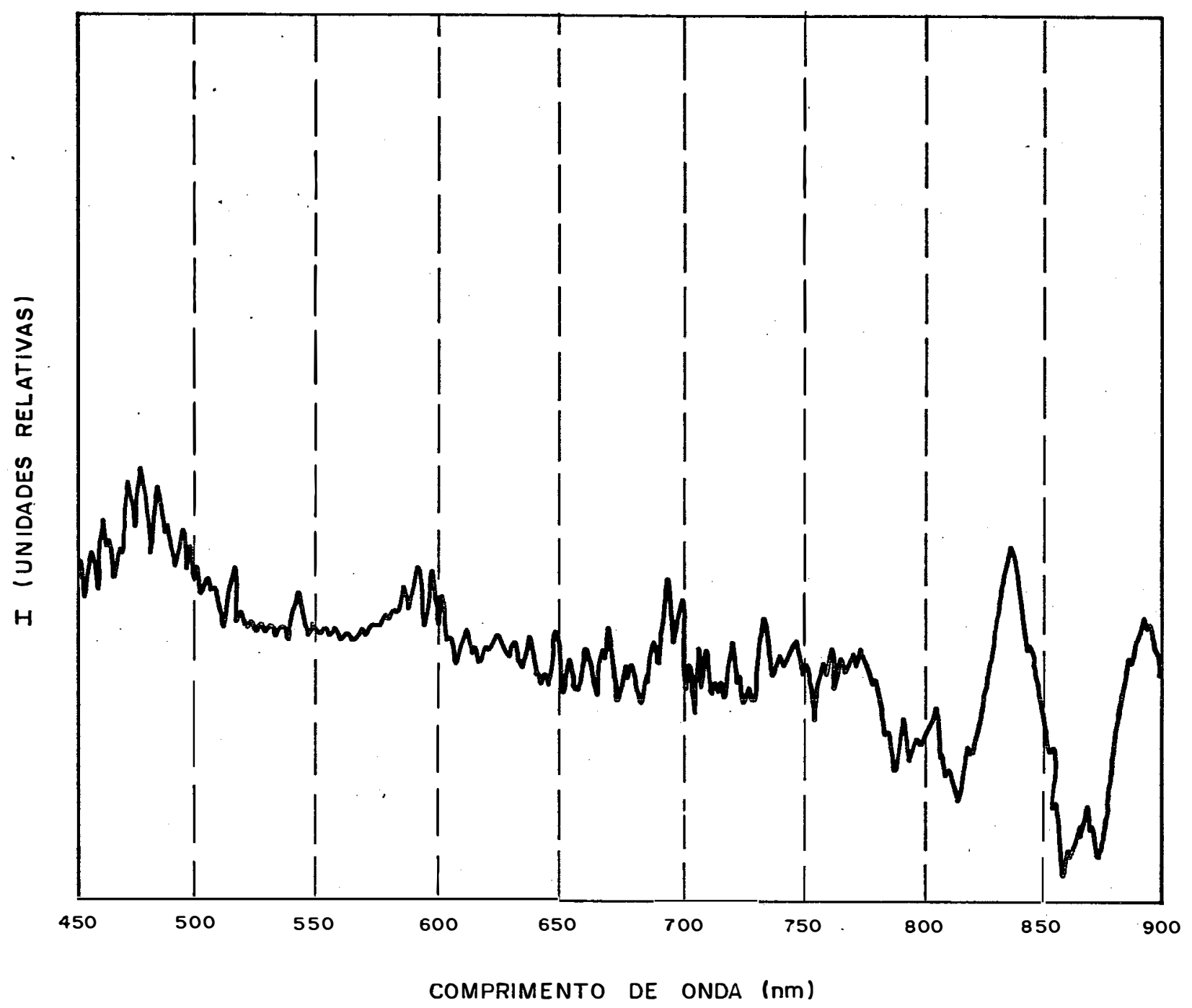

Amostra 3.1 - Unidade LRd - Barão Geraldo. 


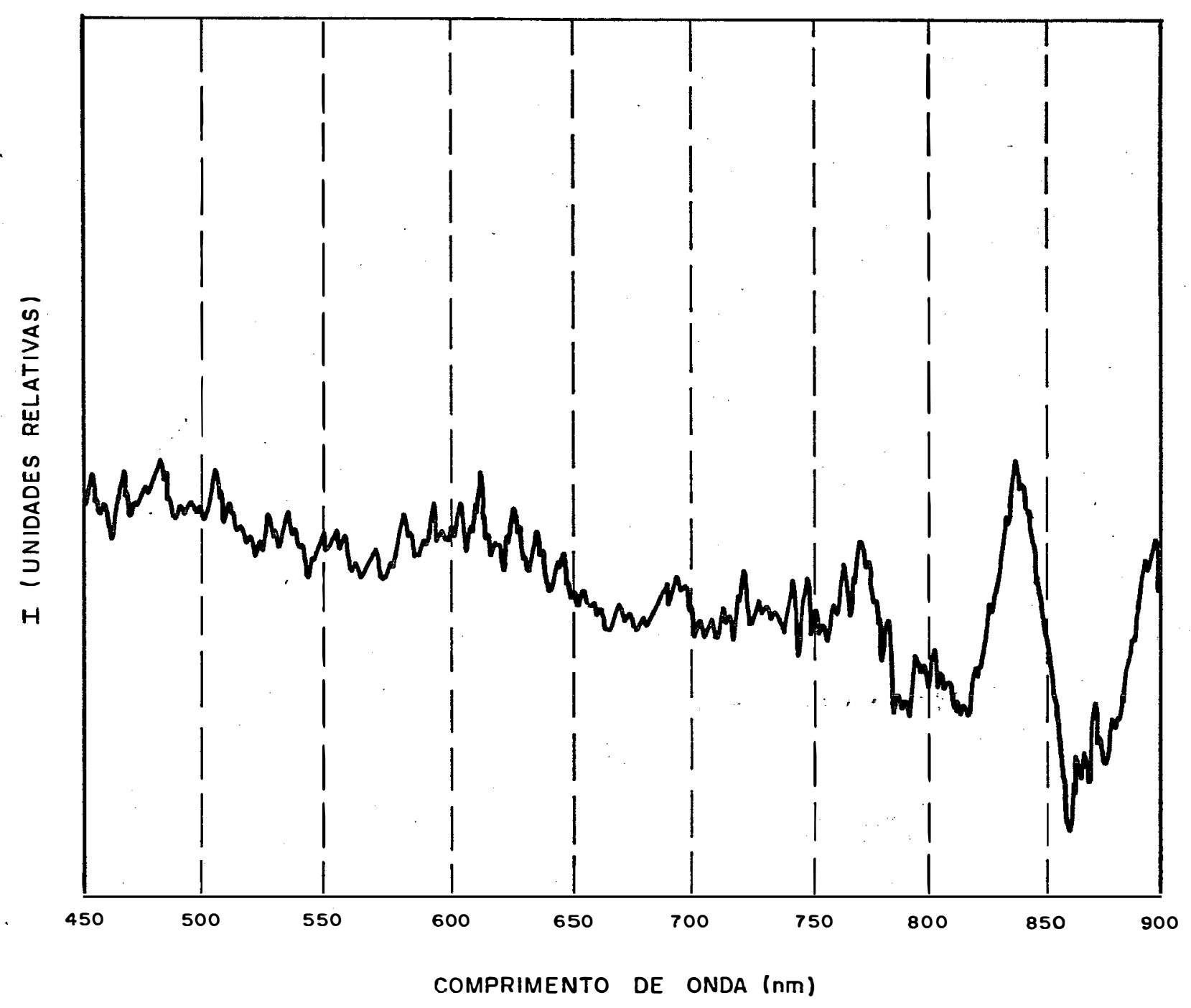

Amostra 3.2 - Unidade LRd - Barão Geraldo. 


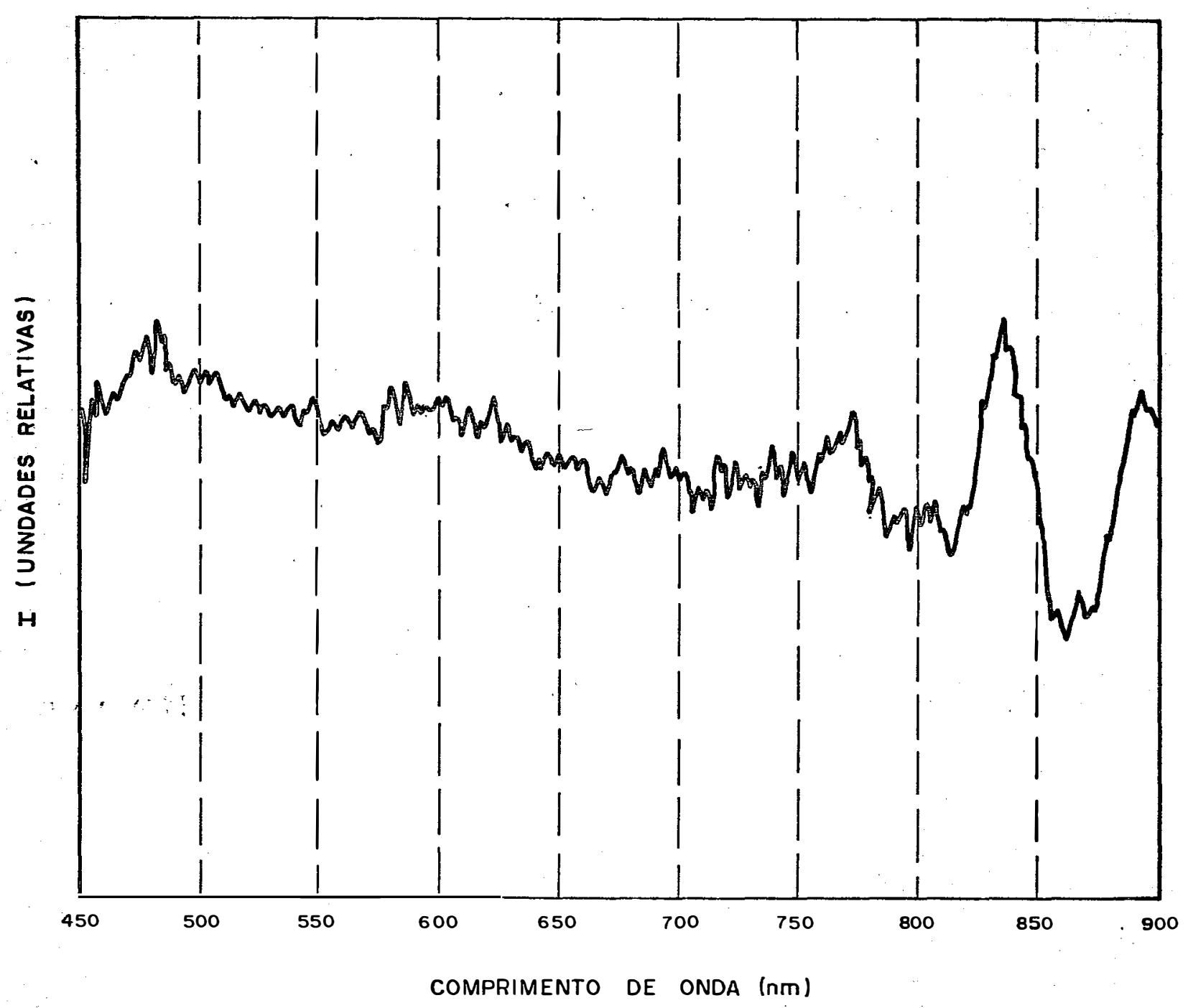

Amostra 3.3 - Unidade LRd - Barão Geraldo. 